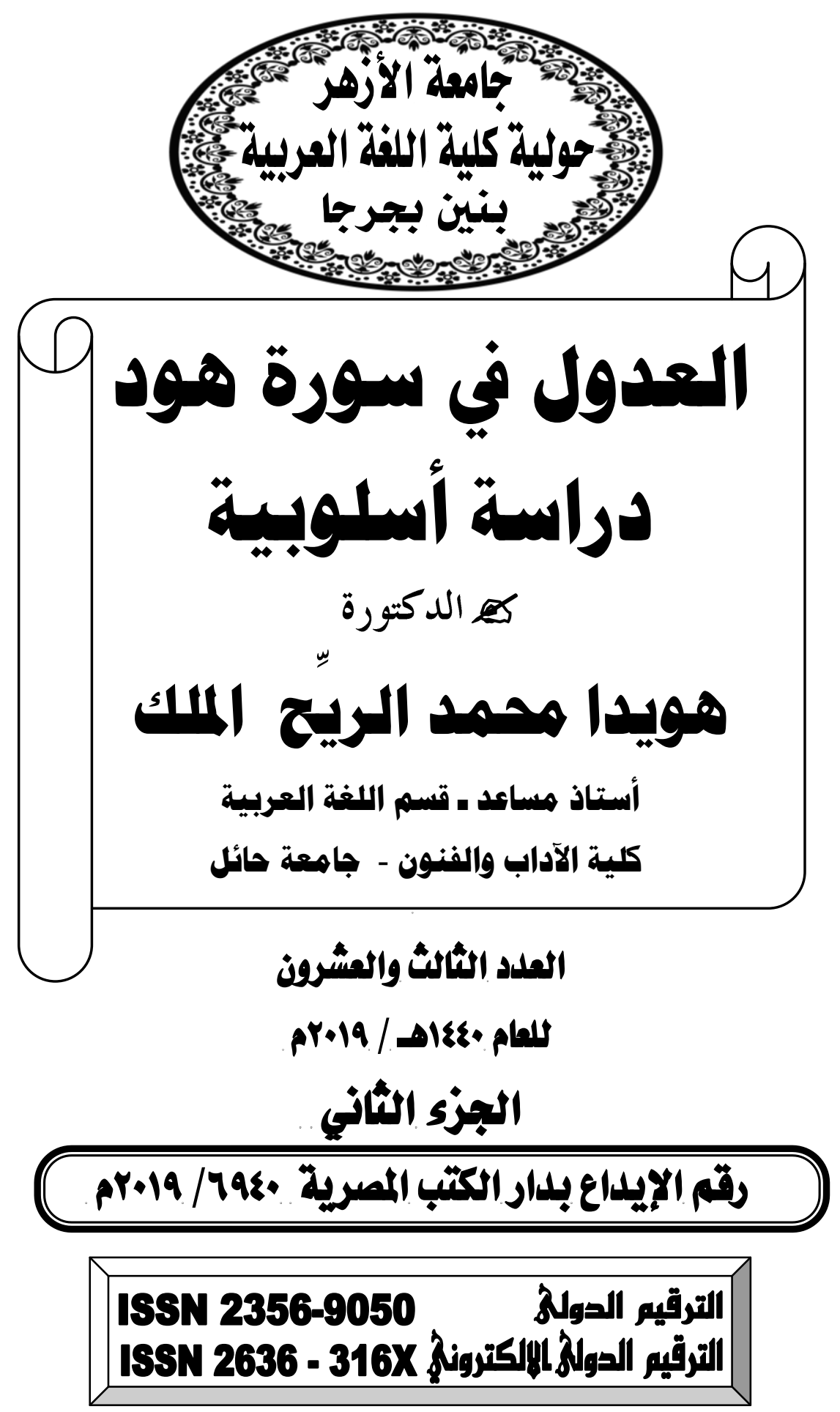



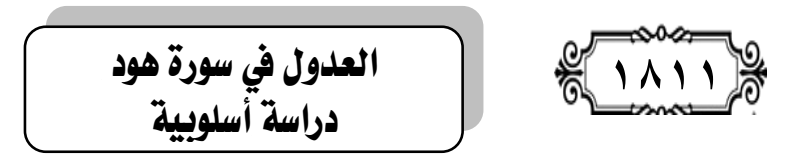

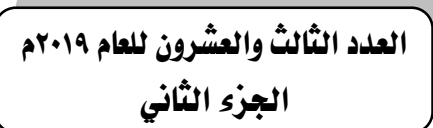

\section{هلغص البحث}

\section{العدول في سورة هود دراسة أسلوبية}

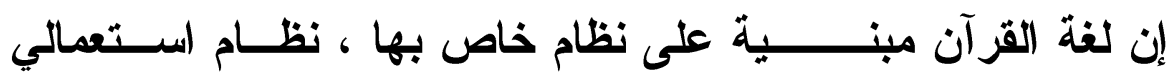

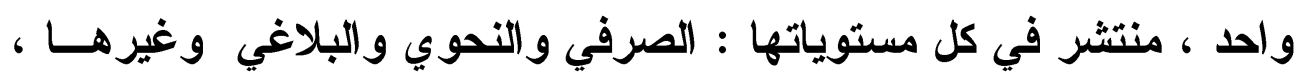

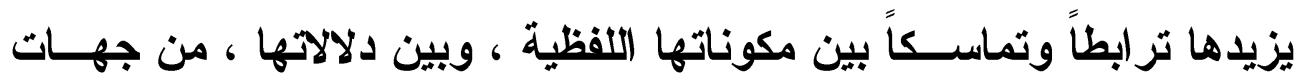

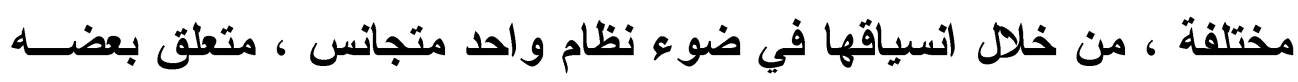

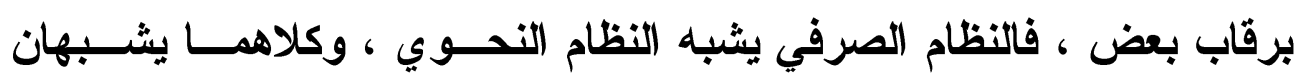

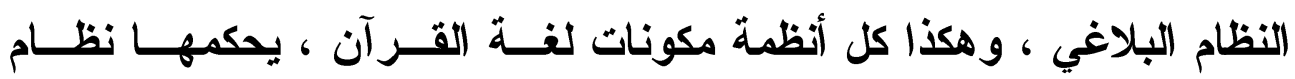
المشابهة.

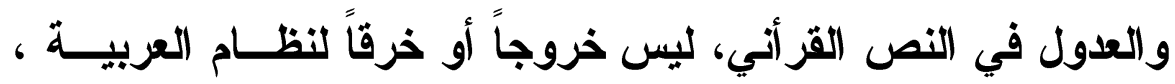

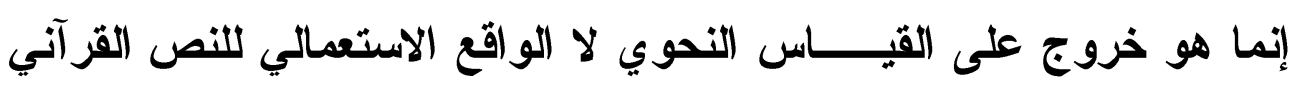

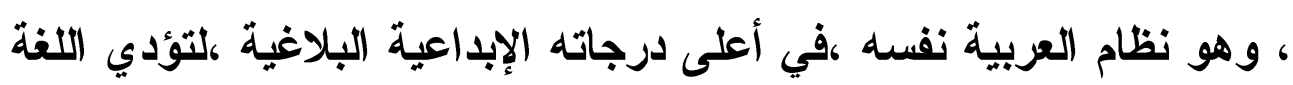

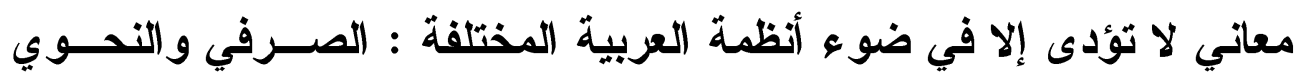

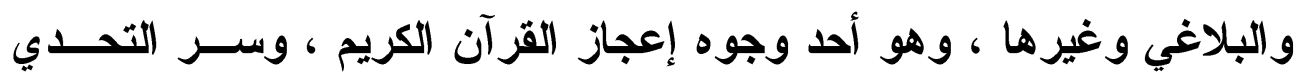

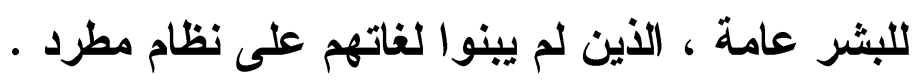

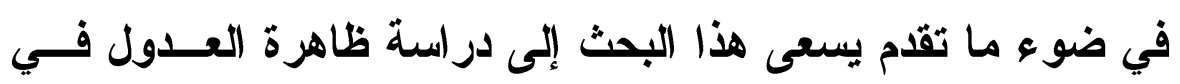

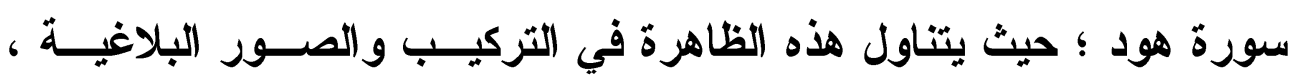

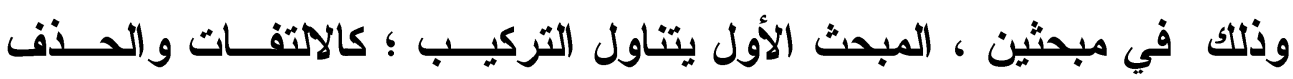

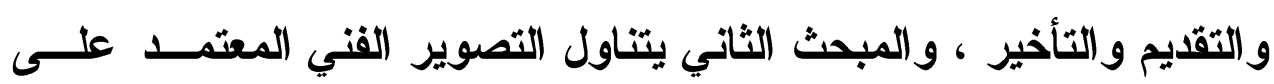

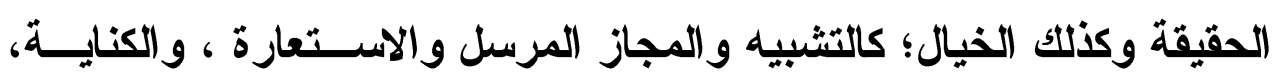

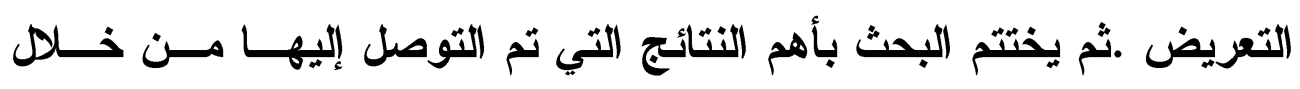

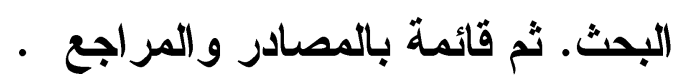

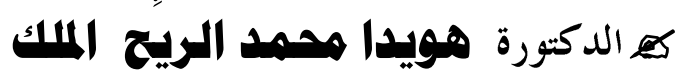

أستاذ هساعد ـ قسم اللغة العربية ـ كلية الآداب والفنون - جاهعة حائل

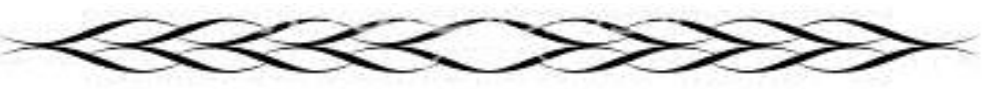




\section{الترقير الدولخ \\ ISSN 2356-9050}

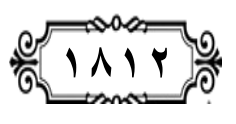

حولية كلية اللفة العربية بجرجا

مجلة علمية محكمة

\section{Abstract}

As the Holly Quran Language is built upon special arrangement, one usage system, and it is disseminated on all of its levels: rhetorical and grammatical and morphological and other, which increases it Consistent coherently between its pronunciations components, and between its significance from different sides, through its drifting in the light of one homogeneous system, have linkage on its each other, the morphological system looks like grammatical system, and both are similar to rhetorical system, thus are all the Holly Quran language component systems, that are adjusted by similarity system.

Re-amendment in Quran text is not a breach to or exit from Arabic Language System, but is an exit from grammatical measurement, it isn't usage status of the Quran text, it is the Arabic system itself, it is on highest degrees of rhetorical creativity, to allow the language performing meanings that don't achieve except in the light of different Arabic System: rhetorical and grammatical and morphological and other, it is one of Holly Quran Miracle faces, and it is a secret for all general mankind who don't demonstrate their language on Steady system.

In the light of what is preceded above, this research seeks to study re-amendment manifestation in Houd Chapter (Surat), whereas it deals with this manifestation in rhetoric images and construction, into two researches, the first research deals with construction, such as postponement, preceding, deletion and turnings, the second research deals with technical imagery depend on truth and function, such as similarity and conforming figurative, rhetoric, metonymy and widening. Then the research concluded within most important results that have been achieved by the research. Then list of sources and references.

Dr. Howaida Mohammed Al - Rih the King

Assistant Professor Department of Arabic Language

Faculty of Arts and Arts - University of Hail 

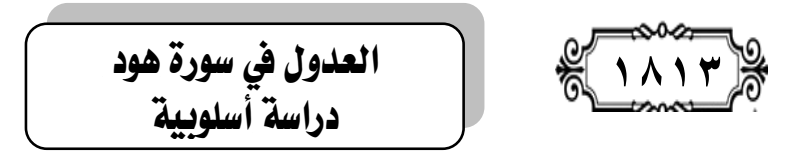

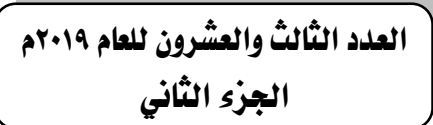

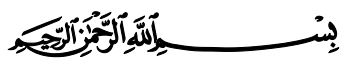

\section{هدخل:}

العدول لغة:

بالرجوع إلى المعاجم نجد أن مادة (ع - د- ل ) ) ، وما يشتق منها

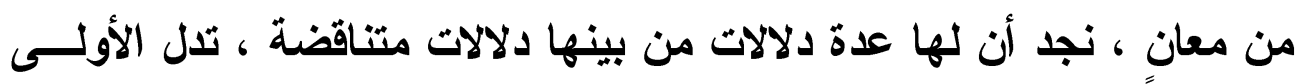

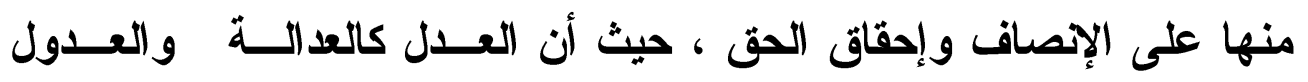

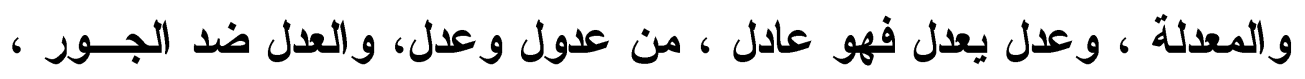

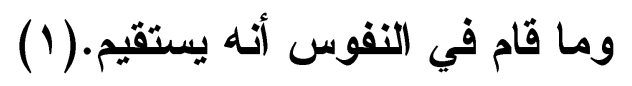
وما يهر -هنا - الدلالة الثانية للعدول ؛ حيث عدل عن الثــيء يعدل وعدولاً ، حاد عن الطريق وجار وعدل إليه عدولاً رجع ، وماله معدل

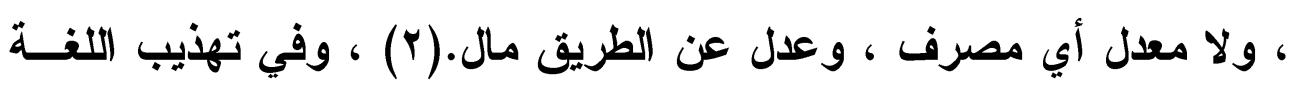

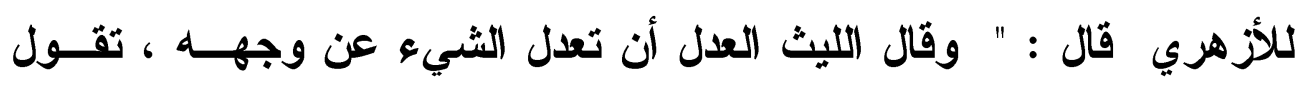

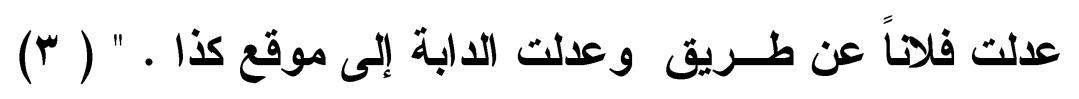
وقال صاحب القاموس المحيط: " وعدلته وعدل عنه يعـدل عـدولاً

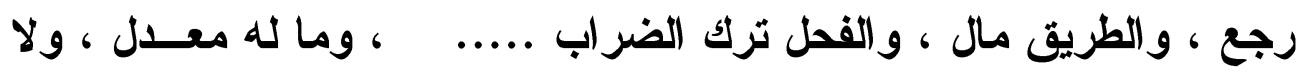

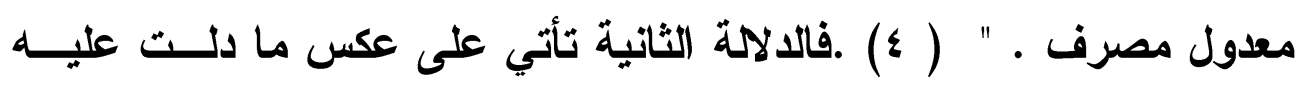

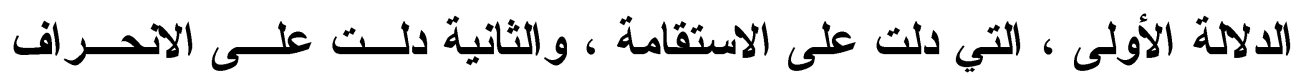

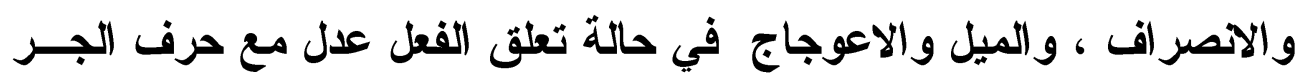

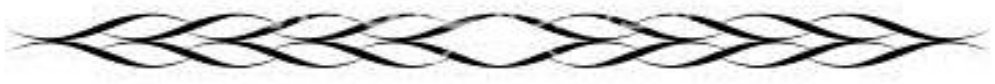


الترقير الدول\$ ISSN 2356-9050

\section{العدول اصطلاحًا :}

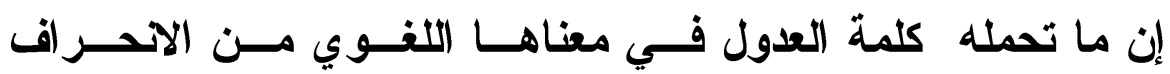

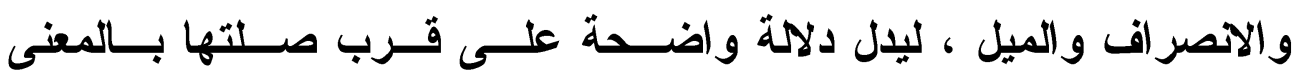

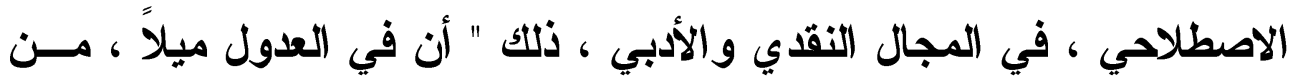

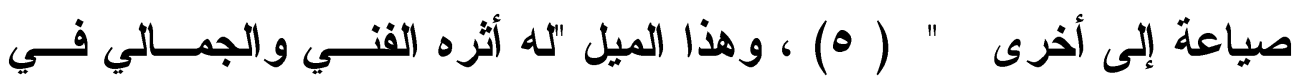
النص الأدبي ، فيعدل من صياغة إلى أخرى ، لإحداث هذا الأثر الأي تنتجه

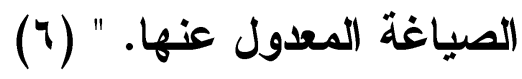

أي أن الكلمة خرجت عن المعنى الحقيقي ، الأي وضعت له ، إلـى إلى

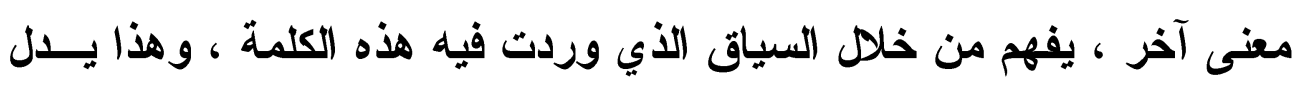

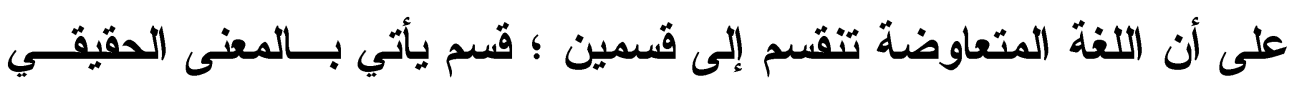

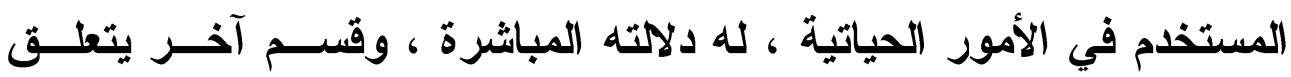

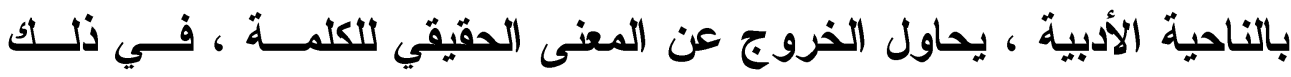

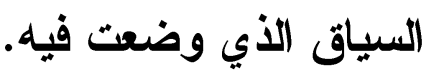

وعلى هذا فالميل والاحمراف في النص الأول هو خروج عن المألوف

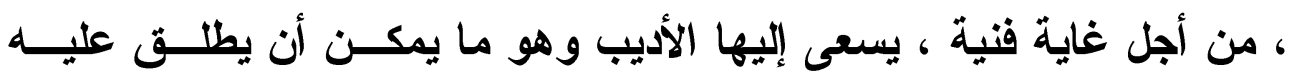

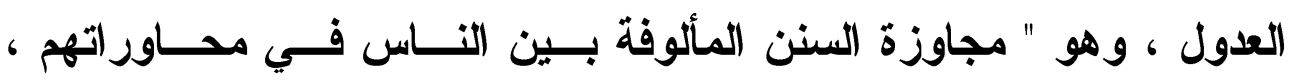

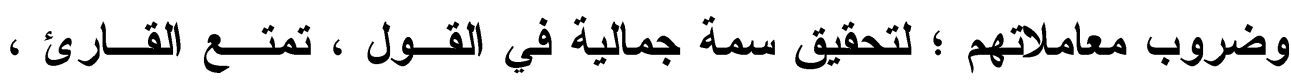

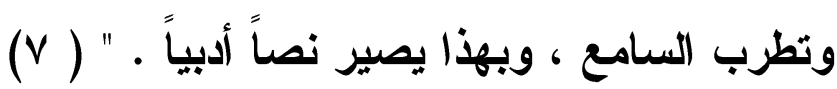

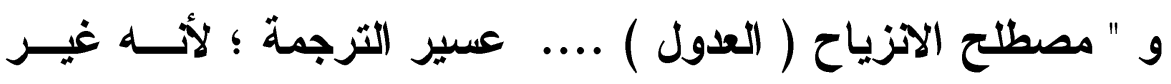

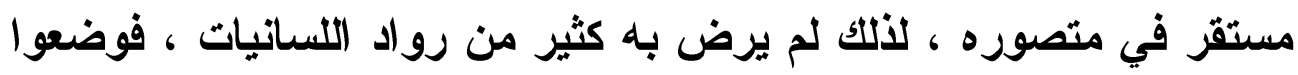

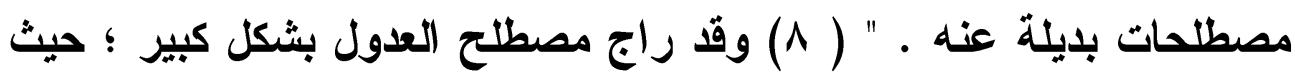




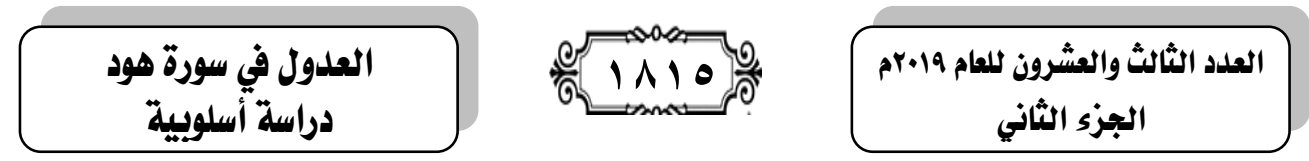

استعمل عند كثير من الدارسين المحثثين ، ويلجأ إليه الأديب أو الثــاعر

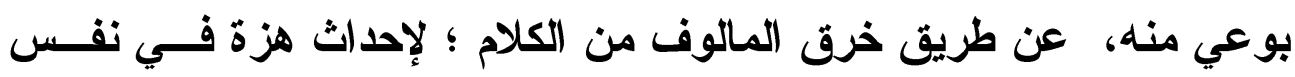

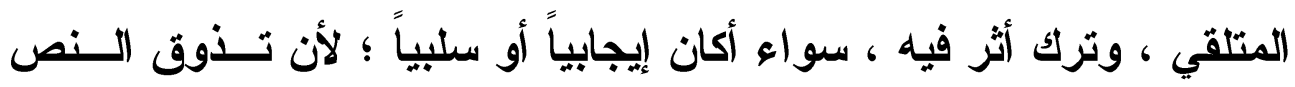

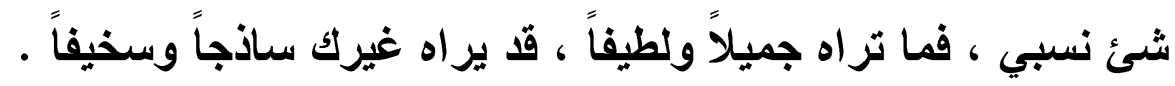

\section{العدول هن حيث هو ظاهرة أسلوبية:}

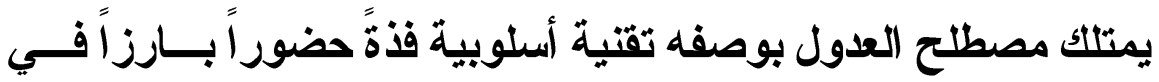

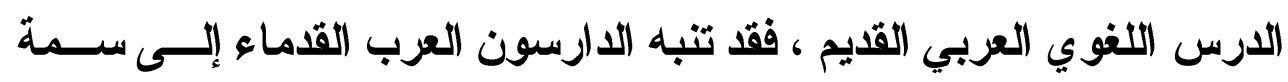

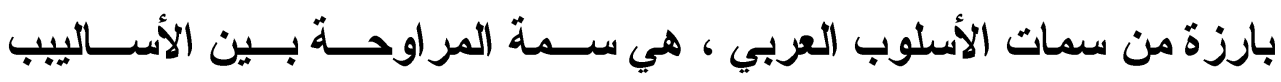

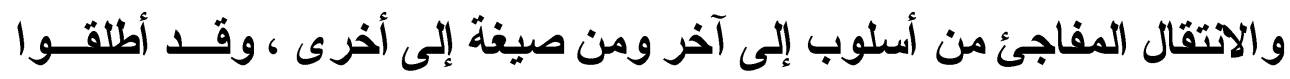

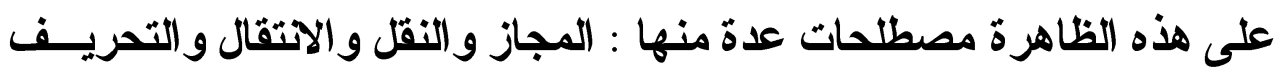

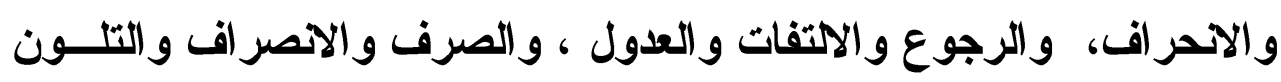

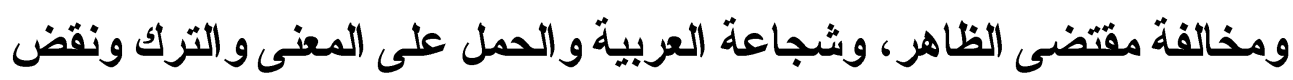
العادة وغير ذلك ـ وهذه المصطلحات المتر ادفة تحيل - في محصلتها النهائية -إلى معنى الخروج عن الأصل وتركه إلى ما ليس بأصل.

وقد تباينت آراء الادرسين في تحديد ماهية القاعدة أو الأصل الذي يتم

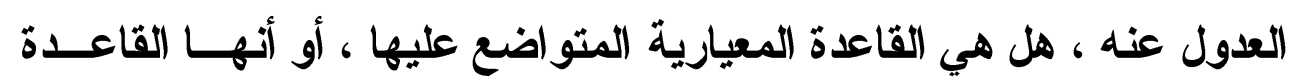

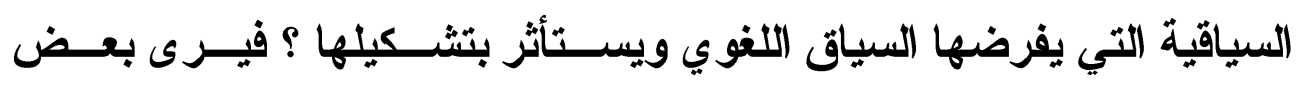

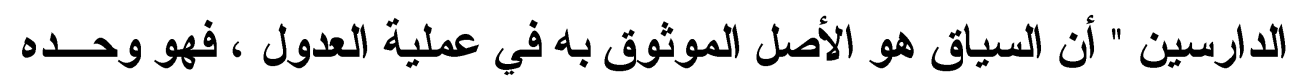

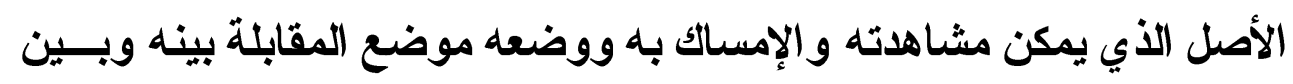

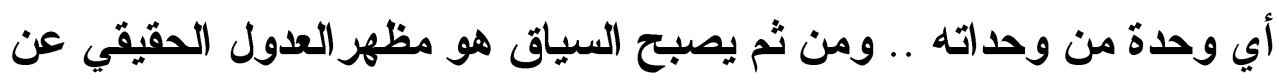

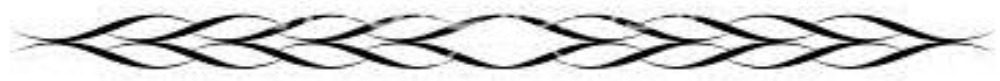




\section{الترقيم الدوله ISSN 2356-9050}

أي قاعدة من القواعد ، ومن ثم يكون جديراً بأن يكون هو القاعدة السائدة في قياس العدول " (1. )

إن اعتماد القاعدة السياقية في مقاربة الظاهرة العدولية في أي نــص يضفي على هذه المقاربة سمة العلمية والموضوعية ، مما يجعـل الأحكـام الصادرة أكثر دقة ، وجنوحاً إلى الصحة ؛ ذللك لأن القاعدة المعـدول عنهــــا

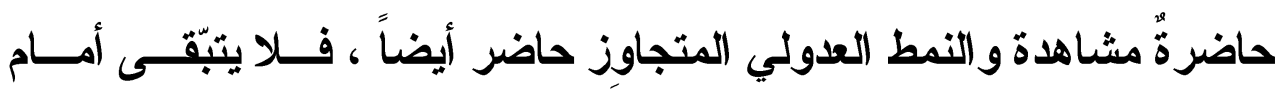
الارس - والحال هذه - إلا أن يُعملذِهنه ويشحذ طاقاته في البحث عن القيم الالاية والإيحائية لهذا العدول. ويختف الوضع بالنسبة للقاعدة المعيارية ، فإن التعويل عليها يجعل بعض الأحكام من قبيل الحدس الظّّي ، الأي لايستث إلى أي قاعدة لغوية.

إن الخلاف حول ماهية القاعدة المعدول عنها في بنية العدول ، خلافُ قديم تمتد جذوره إلى أعماق التر اث البلاغي العربي ، فقديماً اشترط جمهــور البلاغيين في مبحث ( الاتثفات) حضور الضمير الملتفت عنه فـي صــورة الالتفات ، في حين وسع السكاكي الأئرة فلم يشترط وجود الضمير الملتفـــ

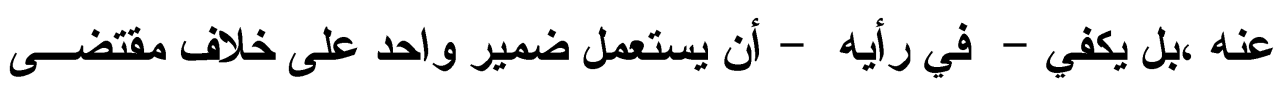

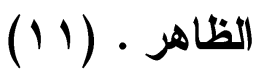

"إن رأي الجمهور يعول على القاعدة السياقية الاخلية / بنية المعدول عنه الحاضرة ، في حين يعـول السكاكي على القاعدة المعيارية الخارجيـــة / بنية المعدول عنه الغائبة عن السياق. ويميل أحد الارسين المحدثين إلى رأي الجمهور في هذه القضية فيقول": والحق أن الـــرأي الــــي تبنـــاه جمهــور البلاغيين في هذا الصدد هو - فيمانرى -أقرب إلى الصواب ؛ ذلتك أنـــه 


\section{العدول في سورة هود دراسة أنسلوبية}

ليس ثمة تحول أو نقل في إير اد نوع من أنو اع الضمائر في مقام يقتضي سواه

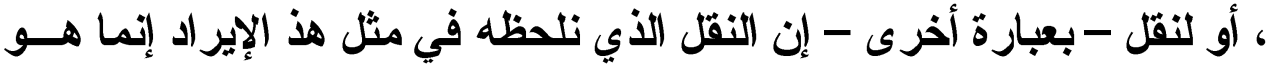

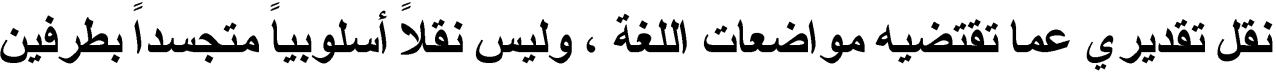
في نسيج الكلام " (Y I (I)

وفي الدرس اللغوي الحديث نجد أصداء لهذا الخلافـ في مقــولتين أو نظريتين أسلوبيتين؛ هما نظرية الاختيار عند جاكبسون ، ونظرية السياق عند

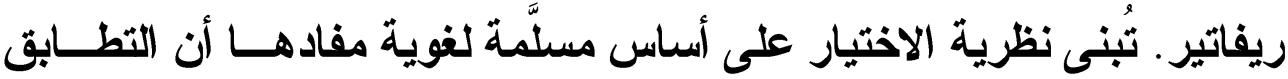
الدلالي التام بين المفردات أمر غير وارد ، فمهما بلغت درجة التقارب الدابل الدالي

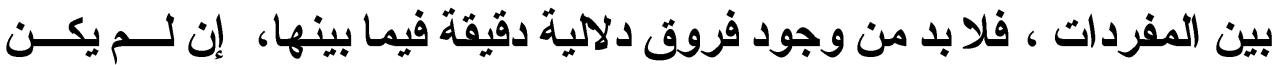

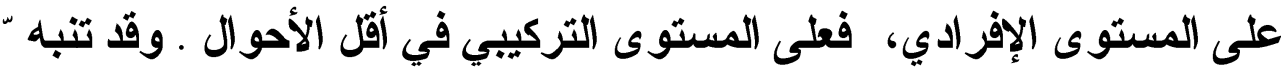

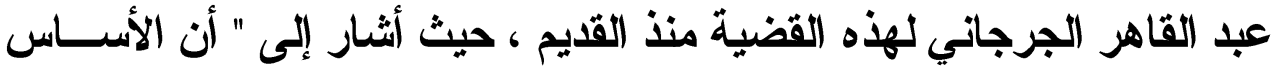
الأي تتم عملية الاختيار بناء” عليه هو مراعاة الفروق بين المعاني الوظيفية

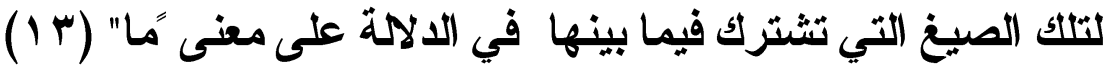
وفي ضوء نظرية الاختيار يصبح توظيف صيغة ما في السياق اللغوي

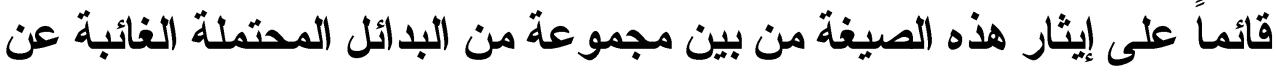

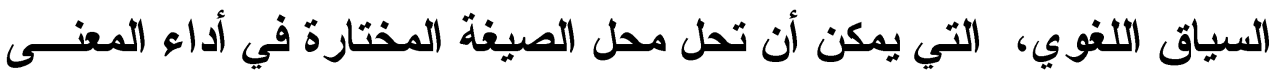

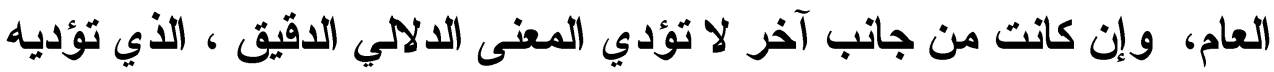
الصيغة المختارة، و الأي لأجله تم اختيار ها واصطفاؤها ، من بين تلك البدائل

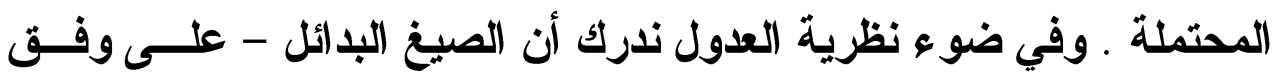

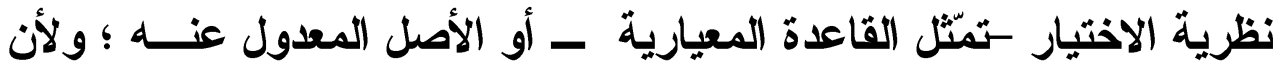
هذه البدائل متعددة ومتنوعة فإن تعددها يقتضي تعـدـد القو اعـــ المعياريـــة

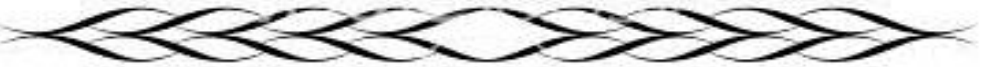




\section{الترقير الدولي \\ ISSN 2356-9050 \\ 난, \\ حولية كلية اللفة العربية بجرجا

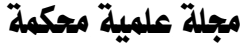

المعدول عنها .فلا يمكن والحال هذه أن نحدد القاعدة المعيارية الصحيحة التي

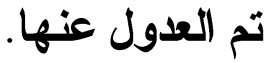

ومن هذه الزاوية ندرك القيمة الأسلوبية لحضور القاعدة / المعدول عنها في السياق اللغوي ـ إن هذا الحضور يوفر على الارس - وهو يقارب بنيــة

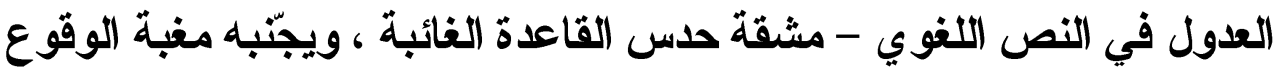
في الأخطاء التقديرية لهذه القاعدة. وفي ضوع نظرية السياق عند ريفـاتير فإن النص " نفسه يحمل في طياته النمطو التجوز في نفس الوقت."( ع ا )

\section{العدول في القرآن الكريم :}

إن لغة القرآن مبنـية على نظام خاص بها ، نظام استعمالي واحد ، منتشر في كل مستوياتها : الصرفي والنحوي والبلاغي وغيرها ، يزيـــها

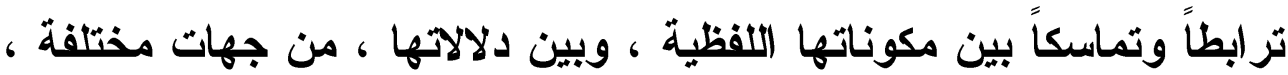
من خلال انسياقها في ضوء نظام واحد منجانس ، متعلـق بعضــهـ برقــاب

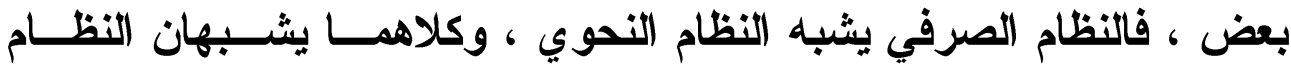
البلاغي ، وهكذا كل أنظمة مكونات لغة القرآن ، يحكمها نظام المشابهة. أما البلاغيون فقل افتبسوا أصلاً نموذجــاً ومعيــارًا ، مــن المــنهج النحوي ، يقيسون عليه العدول و " هو أن الأصل في كل جملة أن يكـون

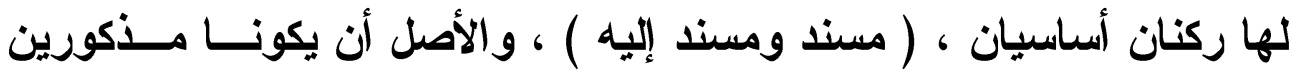

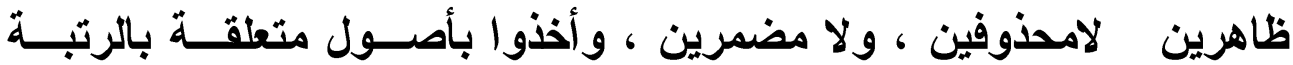

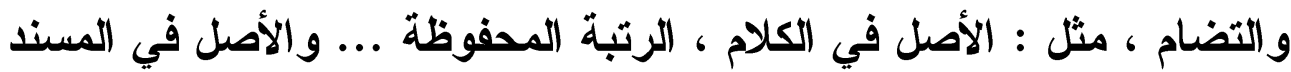

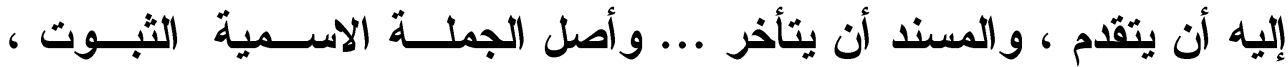

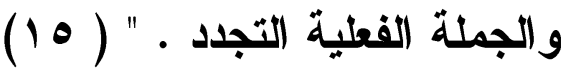




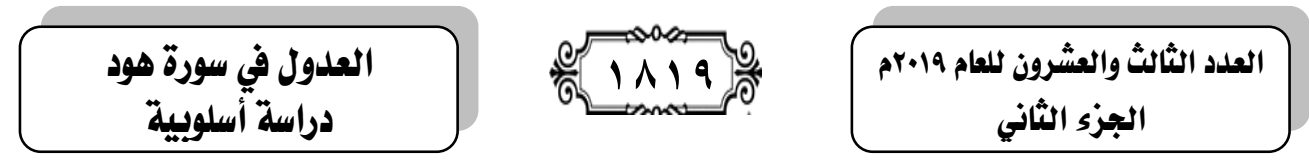

وهو الأصل الذي أطلقوا عليه ( الاستعمال الأصـــلي ) ، و( أصــل

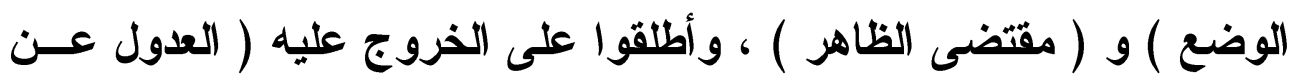

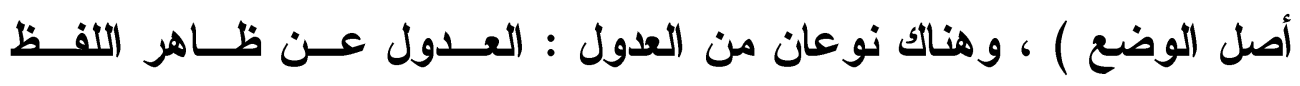

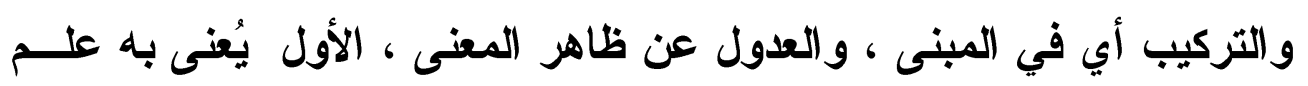

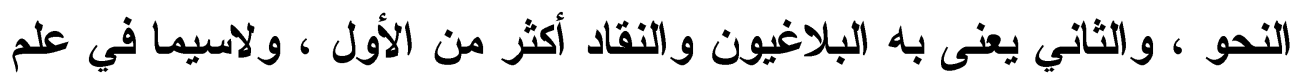

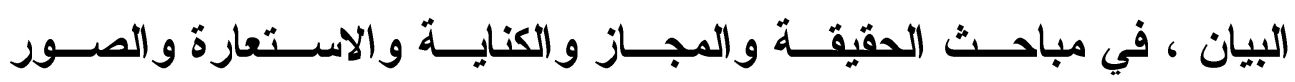

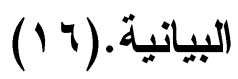

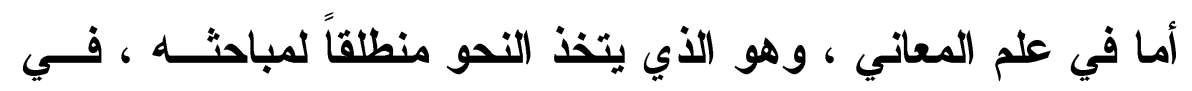

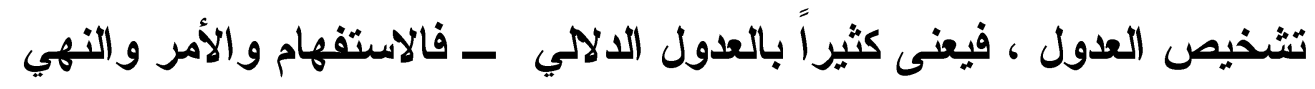

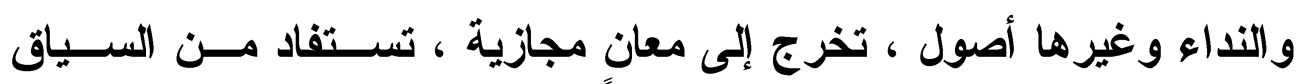

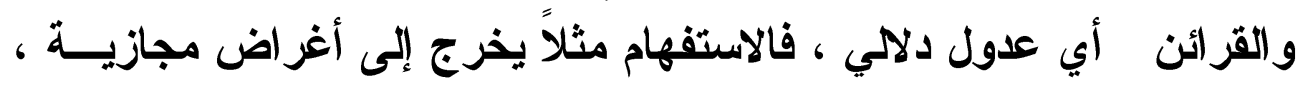

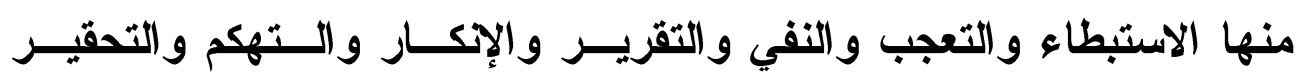

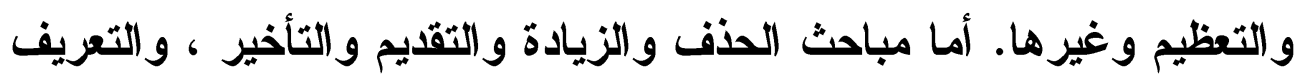

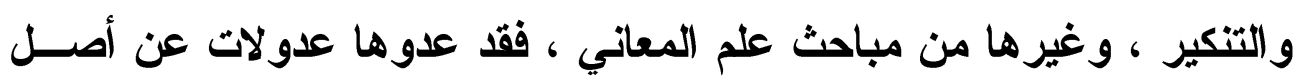

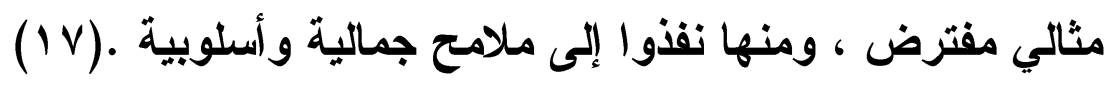

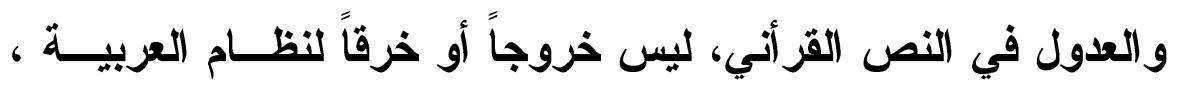

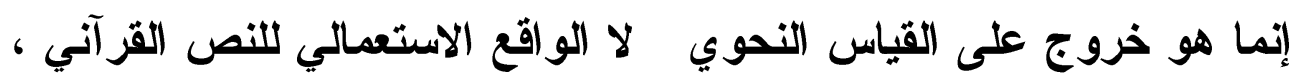

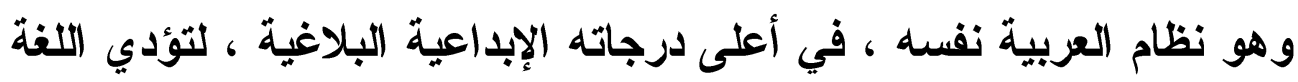

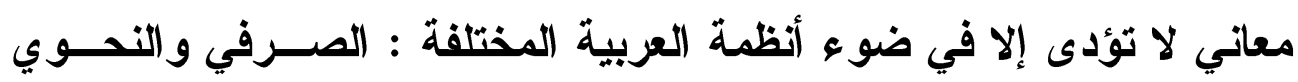

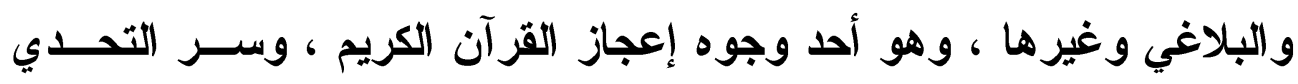

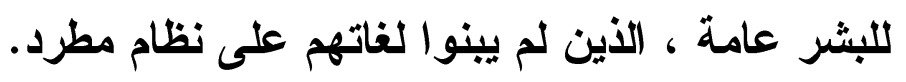




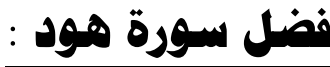

نزلت سورة هود في أصعب الفترات التي كان يعيشها المسلمون في

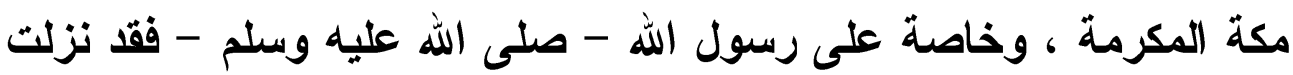

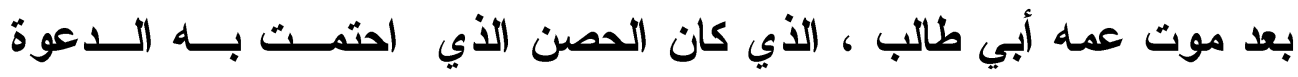

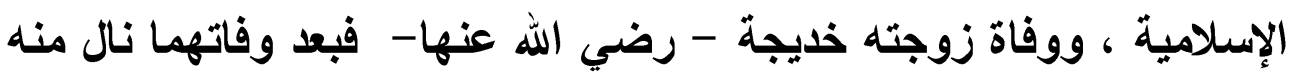

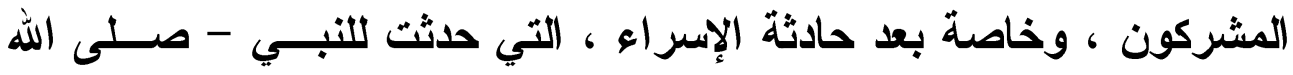

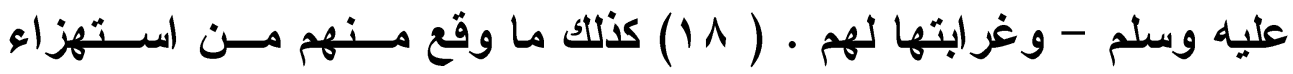

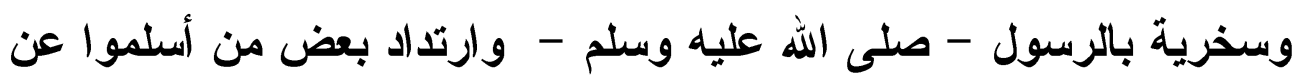

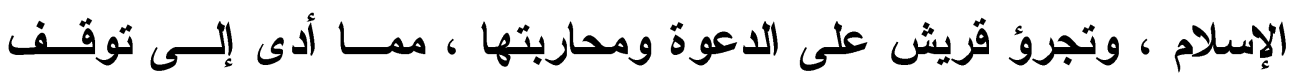

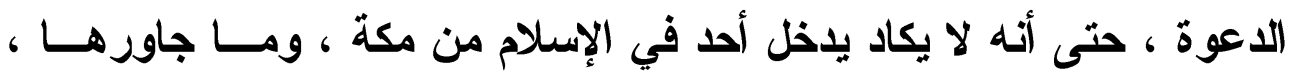

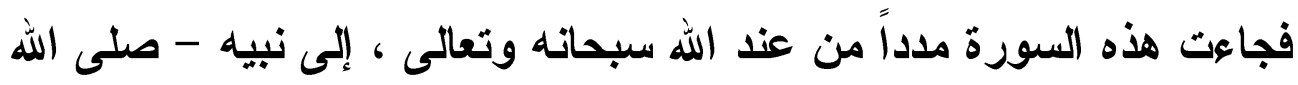

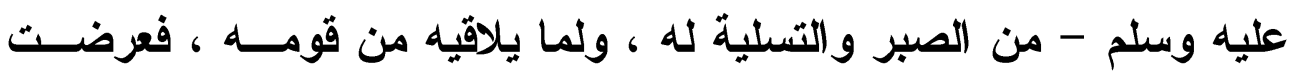

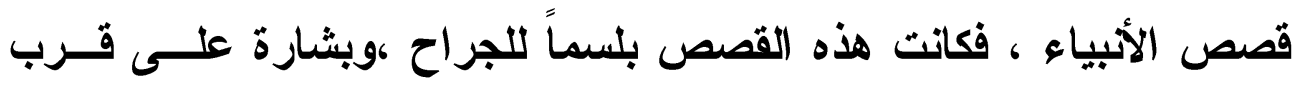
الفرج ، وتأكيد على الثبات على الحقى ، وتسلية لقلبه- صلى الله عليه وسلم

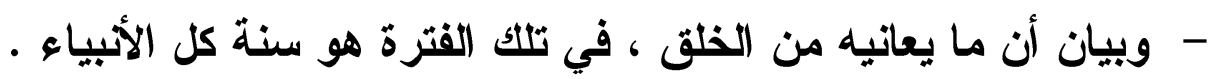
ويقوم هذا البحث على دراسة ظاهرة العدول في سورة هود ؛ حيث الطي يتناول هذه الظاهرة في التركيب الأسلوبي ، وفي الصورة البيانية . 


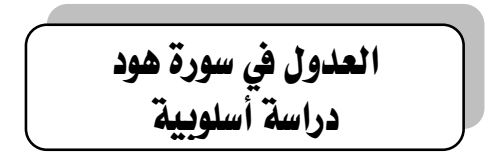

(n)

\section{المبحث الأول \\ العدول في التزكيب}

ويقصد به الخروج على القواعد النحوية ؛التي رسمها النحاة للجملة،

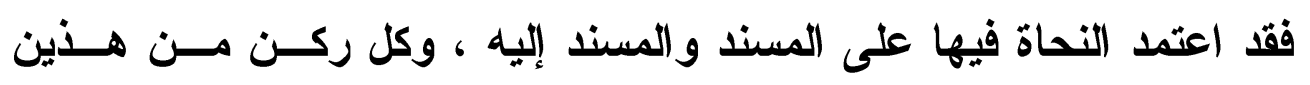

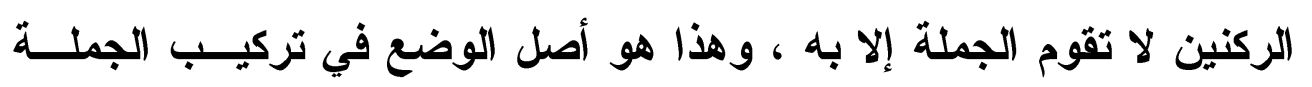

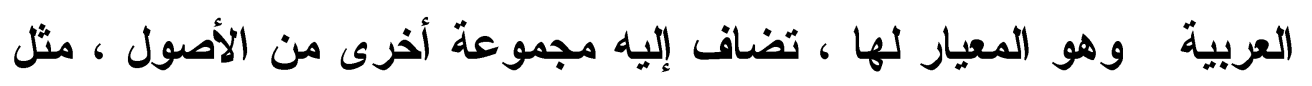

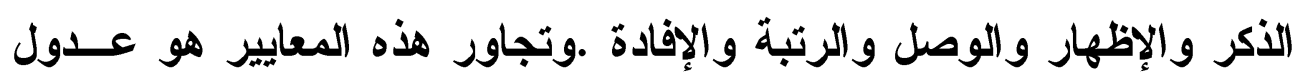

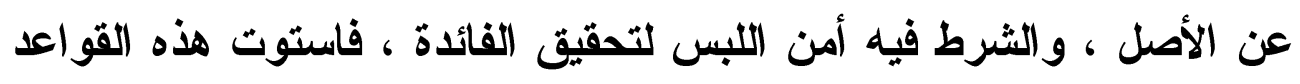

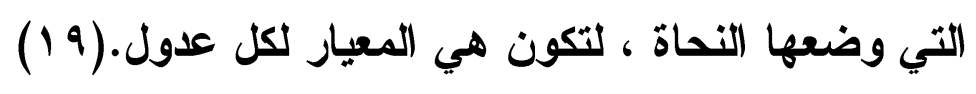

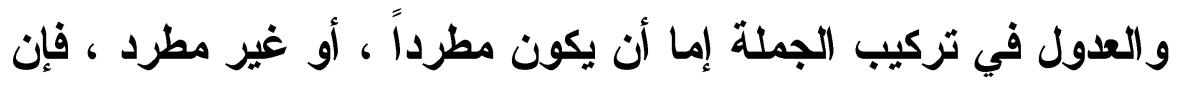

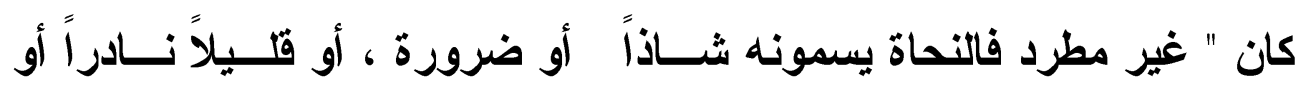

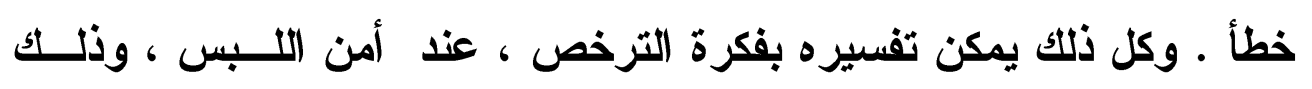

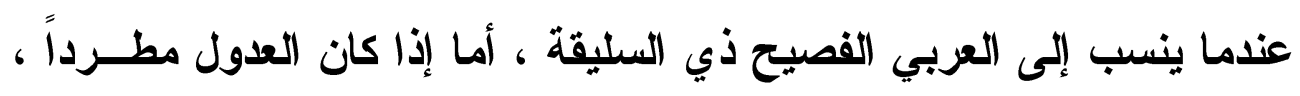

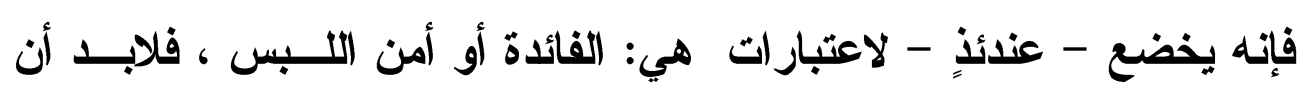

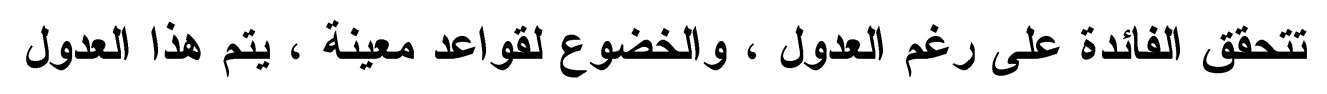

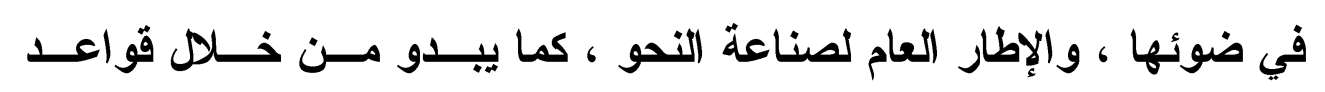

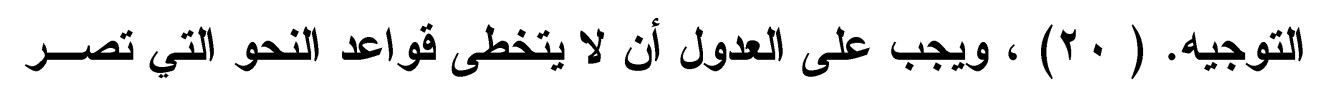
على الفائدة وعدم اللبس. 


\section{الترقيم الدوله \\ ISSN 2356-9050}

\section{وهن العدول في التركيب الالتفات والمذف والتقديم والتأخير.}

\section{الالتفــات}

أسلوب الاتتفات من أكثر الألوان البلاغية اســتخداماً فــي القــرآن

الكريم، وقد سماه بعض البلاغيين بالاعتراض وسماه آخرون الاستدرالك ،

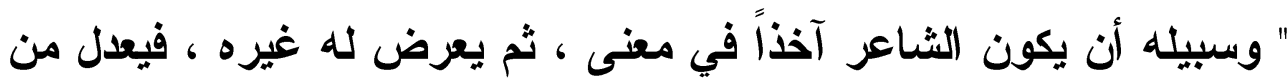

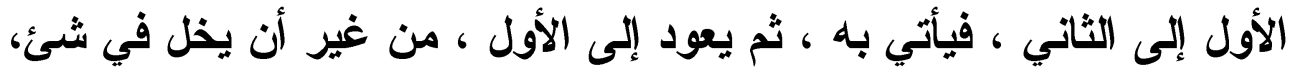

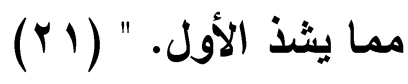

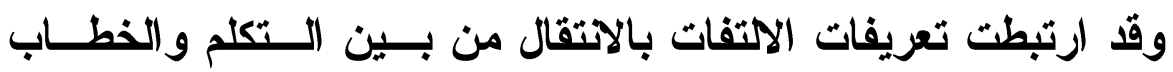

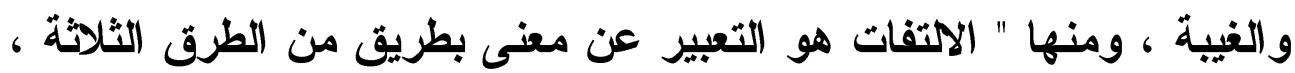

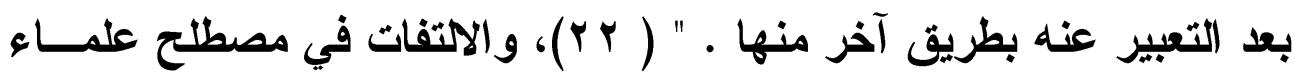
البلاغة هو " العدول من أسلوب في الكلام ، إلى أسلوب آخر ممائل للأول .

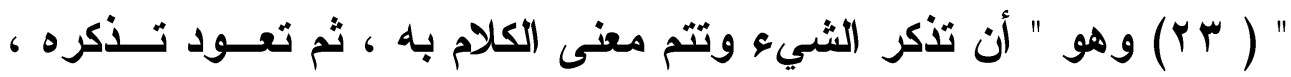
وكأنك تلثقت إليه . " (

وتوسع بعض الدارسين في ظاهرة الالتفات ، فلم يحصر هذه الظاهرة

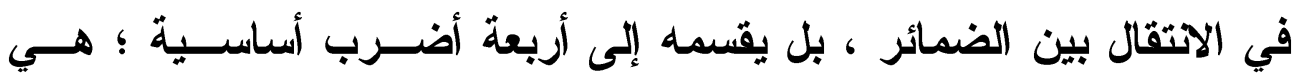
التحول بين ضمائر المتكلم والمخاطب والغائب ، و التحول القائم بين الأفعال

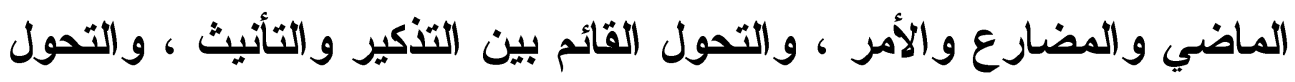

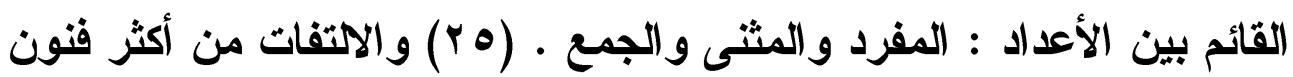

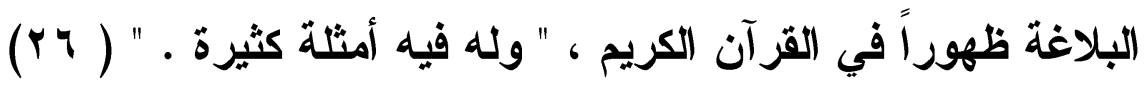




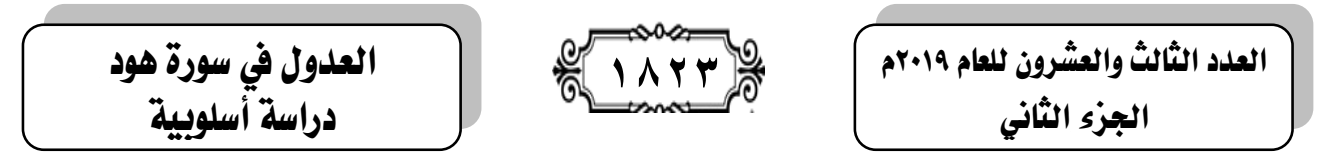

وهن صور الالتفات ، والتي تقربه هن العدول:

الانتقال هن خطاب الواحد إلى خطاب البمع :

ومن ذلك قوله تعالى : (أم يقولون افتراه ، قل فأتوا بعشـر ســور

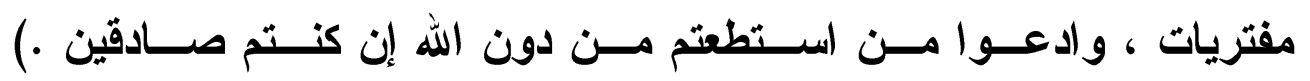
( هود ستريات

في الآية كان الخطاب الأول بلفظ المفرد في قوله ( قل ) ، ثم انتقل

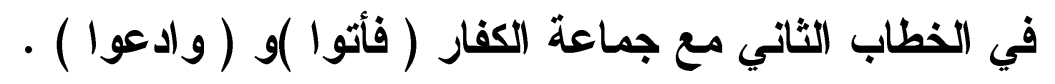

التعبير عن البمهع بلفظ المفرد :

في قوله تعالى : (وجاءه قومه يهرعون إليه ، ومــن قبـل كــانوا

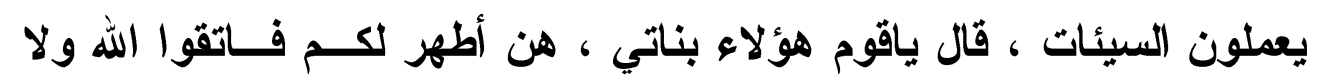

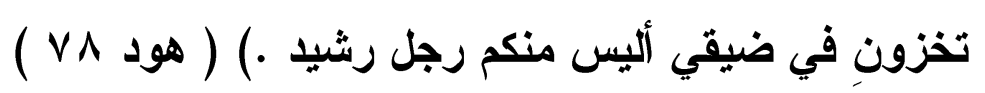
كلمة ( ضيفي ) - هنا - واحد يريد به جميع الضيوف.

\section{التعبير عن المثنى بافظ البمع :}

في قوله تعالى (قال ياقوم هؤلاء بناتي ، هن أطهر لكم ) ( هـود $(\vee \wedge$

كلمة ( بناتي ) جمع ، عبر بها عن المثنى ، فمن المعروف أن للوط

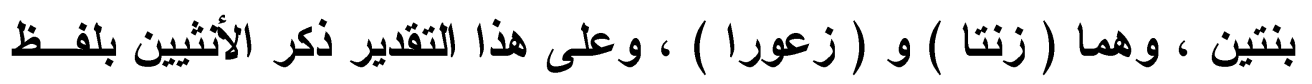

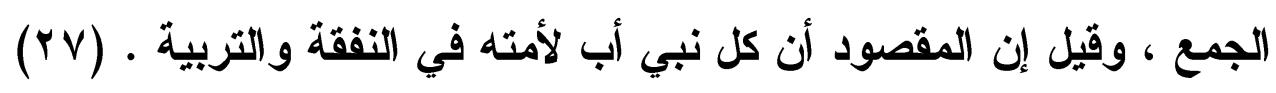


الترقير الدول\$ ISSN 2356-9050
की $114 \varepsilon$

حولية كلية اللفة العربية بجرجا مجلة علمية محكمة

\section{العدول عن الضارع إلى الأهر:}

ويأتي الاتثقال من المضارع إلى الأمر ، وذلك " تعظيماً لحسـال مـن

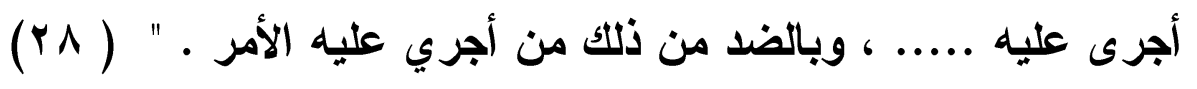
ومن ذلك قوله تعالى : ( قالوا ياهود ما جئتنا ببينة وما نحن بتاركي

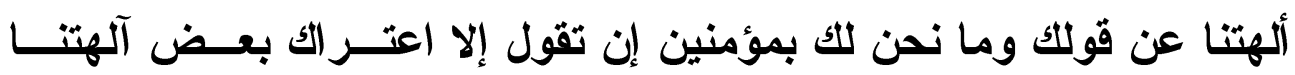

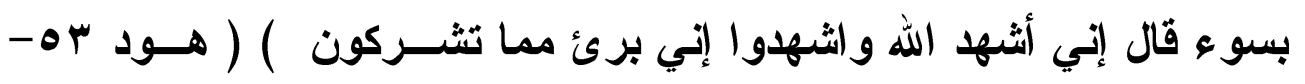
$(0 \leq$

فإنما قال ( أثهر الله ) و ( اشهدوا) ، فقد تضمنت الآية عدولاً عن

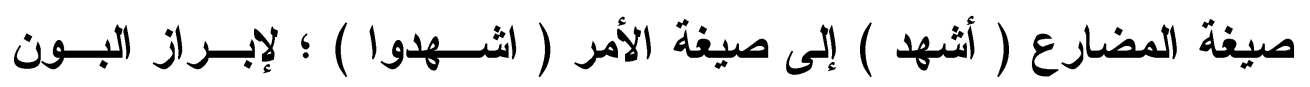

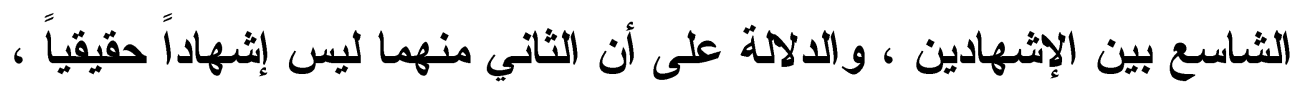

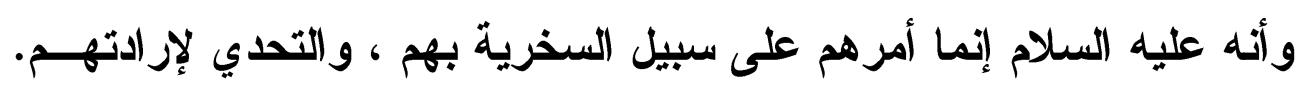
( $r q)$

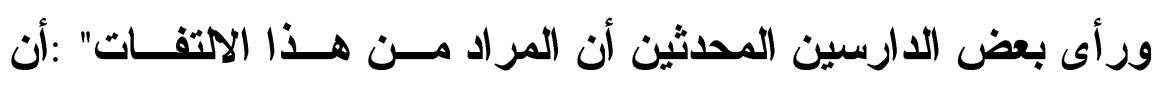

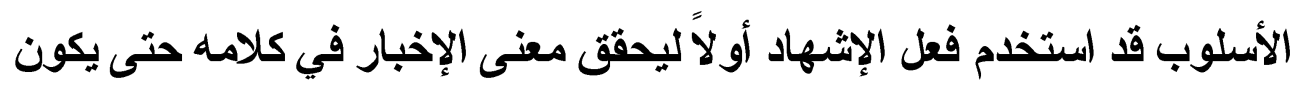
إثثهاده أمراً منتهياً، هذا بخلاف إثثهاده إياهم وقث أورده بصيغة الأمر ، فانتقل

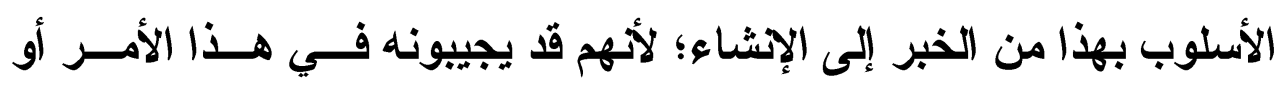

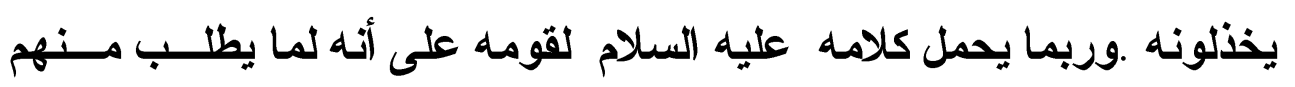

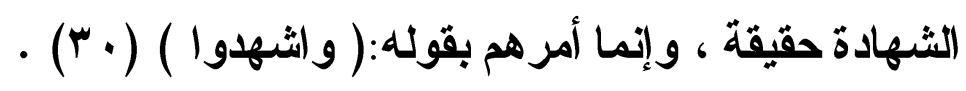
فقد جاء العدول - هنا - ليكون موازناً بمعناه لأن إثهاده الله على

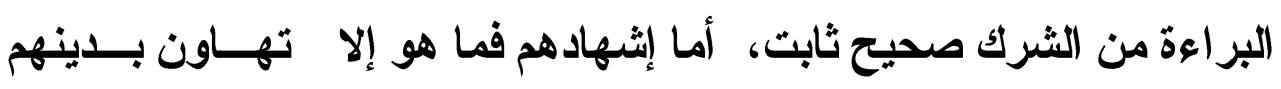

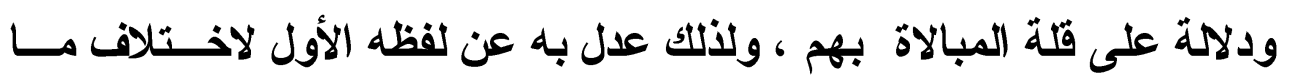




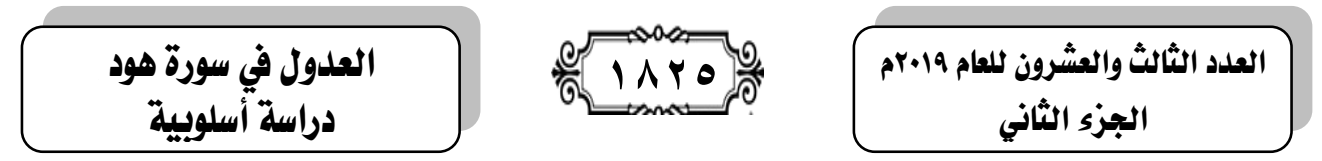

بينهما وجيء بلفظ الأمر .كما أن في عدوله عن صيغة الخبر إلى صيغة الأمر

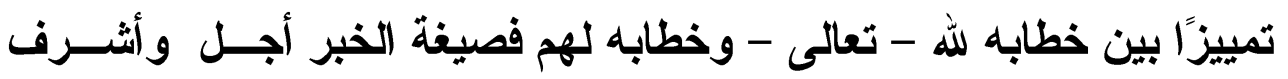
وأوقر للمخاطب من صيغة الأمر .

\section{التعبير عن المستقبل بلفظ الماضي:}

ويأتي التعبير عن المستقبل بلفط الماضي ، وذلك ليكون دلالة على الكى

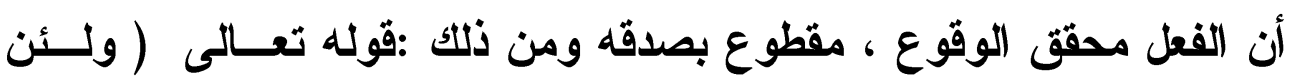

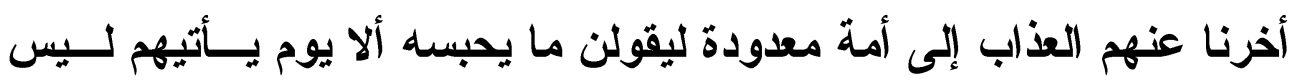

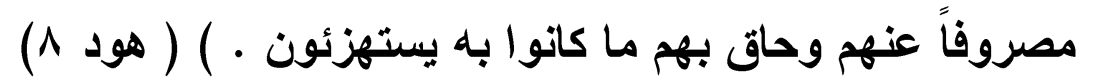

فإن الله - سبحانه وتعالى - عبر بالفعل الماضي ( وحاق ) ، مع أن

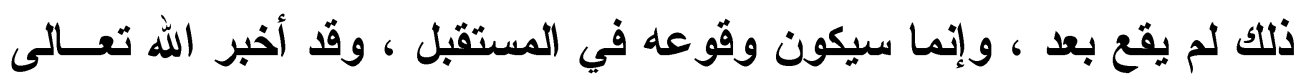

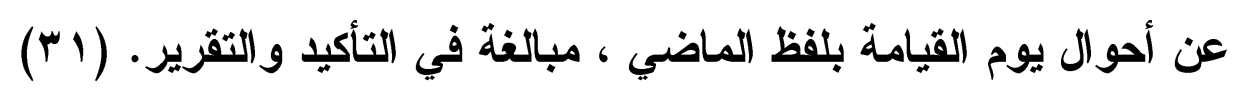
- وقوله نعالى :(من كان يريد الحياة الانيا وزينتـــــــهـا نوفـ إليهم

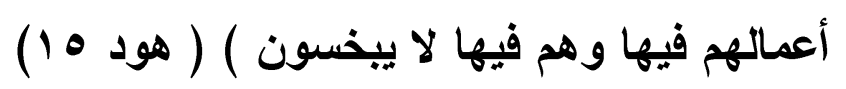
( من كان ) في موضع جزم الثرط ، وجوابه ( نوف ) ، أي مسن

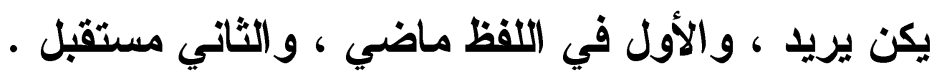

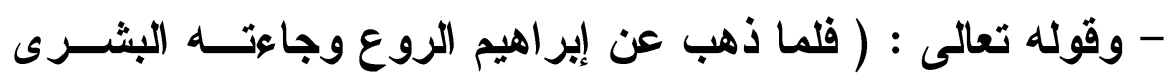

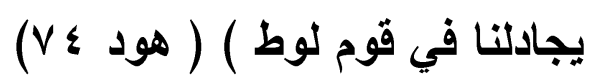

كان الأصل في جواب ( لما ) أن يكون بصيغة الماضي ، و المعنى لما

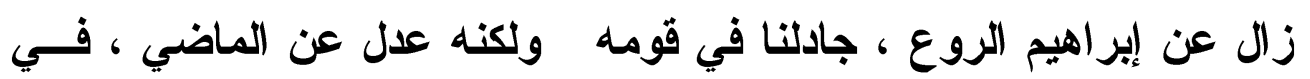

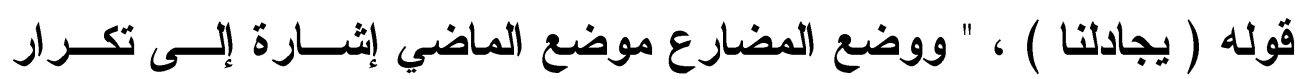

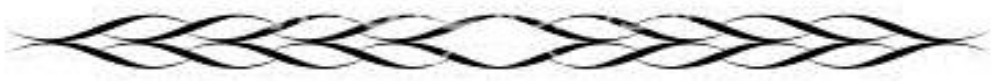




\section{الترقير الدولخ}

ISSN 2356-9050
(1) 1147
حولية كلية اللفة العربية بجرجا مجية مجلة علمية محكمة

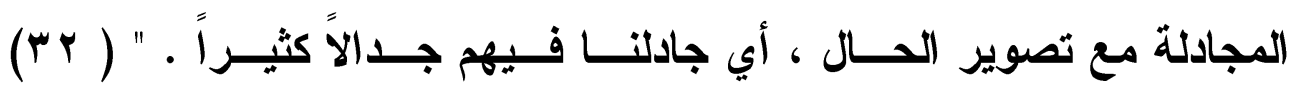
واستعمال صيغة المضارع قد أفاد تكرار المجادلة من إبراهيم - عليه السلام - مرة بعد أخرى ، و " فائدة سوق الماضي في موضع المستقبل ، الإشارة

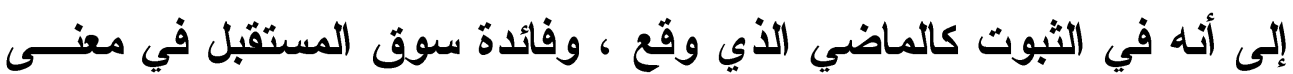
الماضي، الإعلام بأن الأمر مستمر • " ( بr)

\section{التهبيز باسيم الإفهول عن الفهل المستقبل :}

ومن ذلك قوله تعالى : (إن في ذلك لآية لمن خاف عذاب الآخرة ذلك يوم مجموع له الناس وذللك يوم مشهود)( هود ب + 1) فقد جاء اسم المفعول ( مجموع ) ، الأي هو على الفعل المستقبل ، الأي هو ( يجمع ) لما فيـهـ

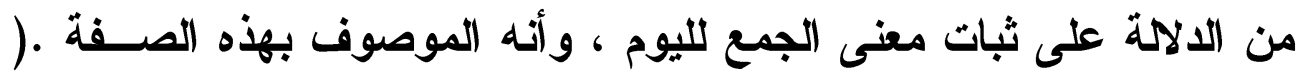

\section{الالتفات هن الغطاب إلى التكلم :}

في قوله تعالى : " واستغقروا ربكم ثم توبوا إليه إن ربـي رحسيم ودود ـ " ( هود 9) فعبر أولاً عن الأت بطريث الخطاب ، في قوله تعالى ( واستغفروا ) ، ثم التفت فعبر عنها بطريق التكلم ، في قولــه ( إن ربـي رحيم ودود )

\section{التعبير عن الفهعول باسم الفاعل:}

وذلك في قوله تعالى : ( قال سآوي إلى جبل يعصمني من الماء قال

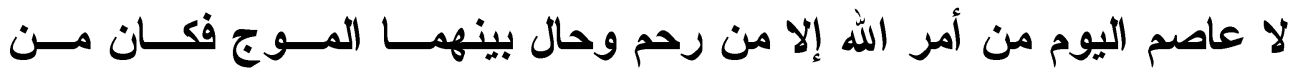
المغرقين · ) ( هود r ) وذلك في قوله ( لا عاصم ) ) ، أي لا معصوم من

\section{6}




\begin{tabular}{|c|c|c|}
\hline العدول في سورة هوردة أسلوبية & I $1 \wedge Y V$ ? & العدد الثالث والعشروذ للعام 19+الجزم الثاني \\
\hline
\end{tabular}

وهكذا نجد أن التلوين بين صيخ الأفعال، يحمل فــي طياتــه دلالات

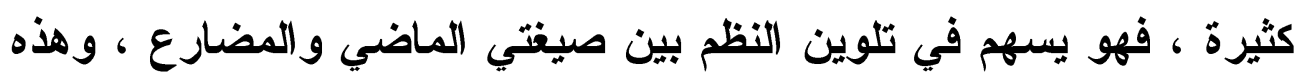

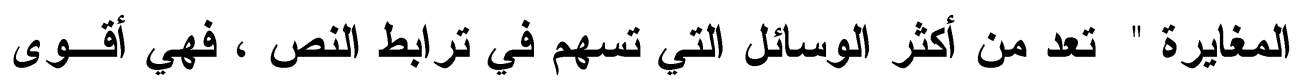

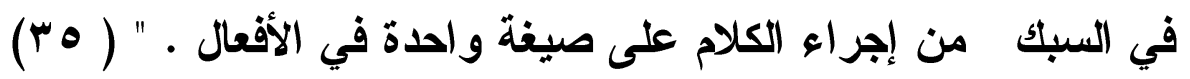
وقد أكثر أهل البلاغة من العرب من الآتفات ؛ " لأهه يرون الاتقال

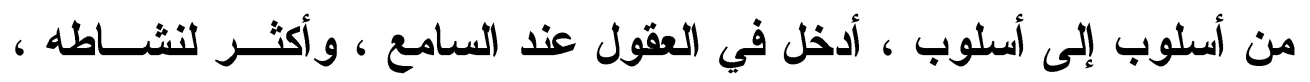

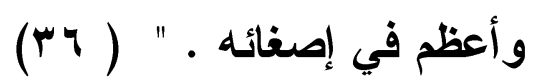

ثانسيا

\section{الحذف}

الحذف من الموضوعات المهمة في الارس البلاغي ؛ وذلك لقدرتــه.

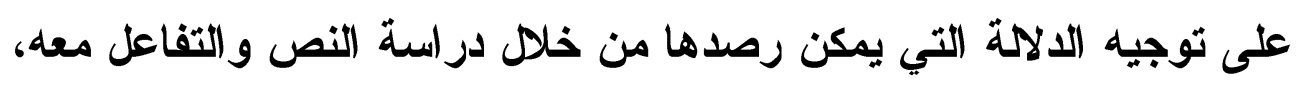
والحذف من خصائص اللغة العربية ، وفيه تكمن قيمتها البيانية و التعبيرية.

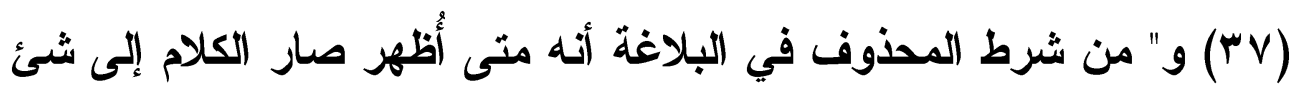

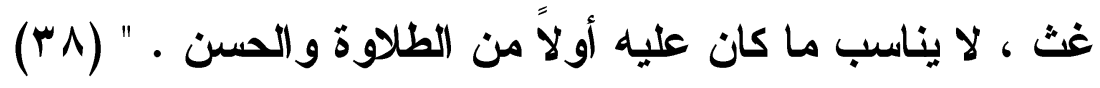
والحذف ليس تلاعباً بالأفاظ ، يجوز فطله مرة ، وتركه مرة ، بل هو ،

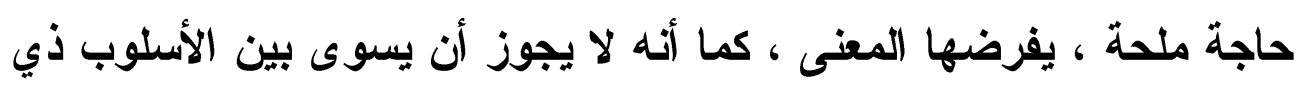

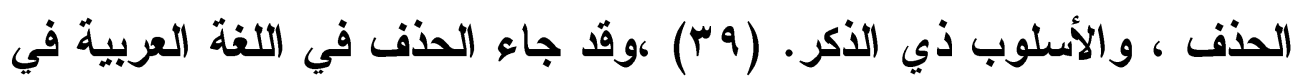

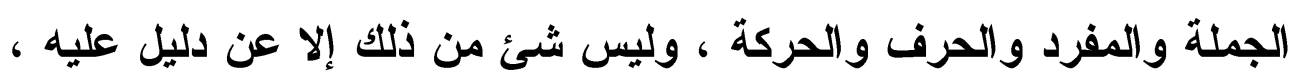

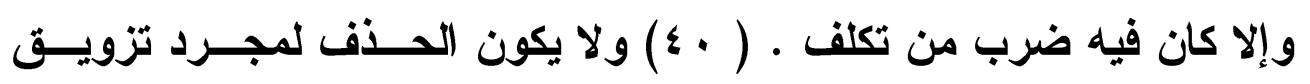

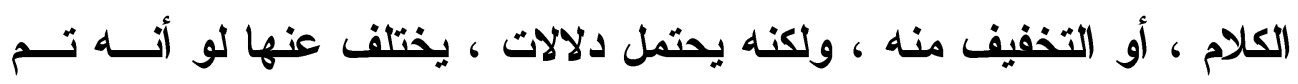

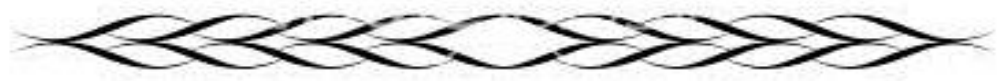




\section{الترقيم الدوله \\ ISSN 2356-9050}

الأكر دون الحذف ؛ لأن " الزيادة في الحد نقصــان ... وإذا طــال الكــلام عرضت له أسباب التكلف.

ولا خير في شئ يأتي به التكلف . ( اءع) ، وللحذف أثزه النفسي في المتلقي ، ومن قبل في المبدع فــ " المحذوف إذا ظهر في اللفظ ، زال ما يختلج في الوهم من المراد ..... . وكلما كان الثــعور بالمحــذوف أعسـر

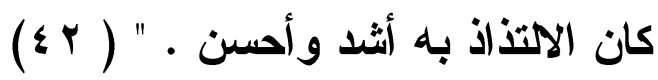
ومن أقسام الهذف في سورة هود: الاقتتطاع: ويقصد به :" أن يستدل بالفعل لشيئين ، وهو في الحقيقة لأحدهما ، فيضمر للآخر فعل يناسبه . " (بع)

ومن أمثثة الاقتطاع في سورة هود قوله تعالى : (أم يقولون افتـــراه قل فأتوا بعشر سور مثله مفتريات وادعوا من استطعتم من دون الله إن كنتم صادقين • ) ( هود r ا ) والتقدير : إن كنتم صادقين ادعوا من استطعتم .

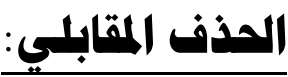

والمقصود به" أن يجتمع في الكلام متقابلان، فيحذف من واحلٍ منهما

$$
\text { مقابله؛ لالامة الآخر عليه" (ع ع ) }
$$

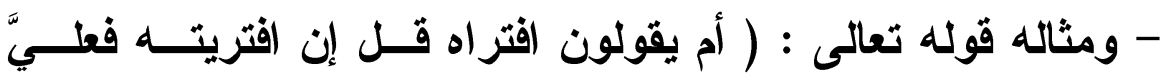
إجرامي وأنا برئ مما يجرمون ) ( هود هب) والأصل : وإن افتريته فعلــيَّ إجرامي ، وأنتم براء منه ، وأنا برئ مما تجرمون. والآية على تقدير" :قل إن افتريته فعلي إجر امي وأنتم بريئون مما أجرمت، وإن افتريتمــوه فعلـيكم 


\section{العدول في سورة هود دراسة أسلوبية}

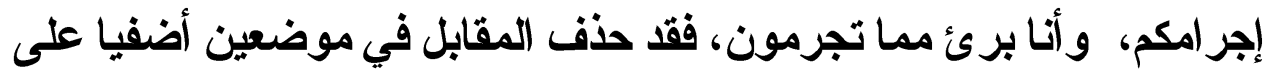

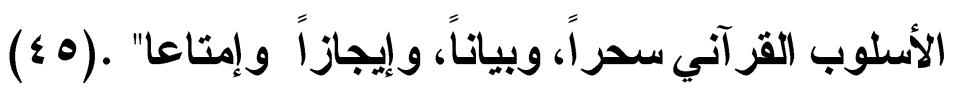

الاختزال :

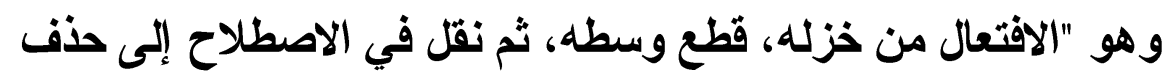

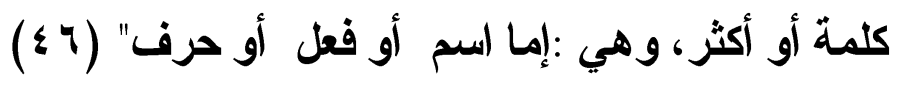
حذف الأسماء: حذف الفاعل :

ويحذف الفاعل إذا دلت عليه دلالة ، ويأتي حتف الفاعـلـل إذا بنــي

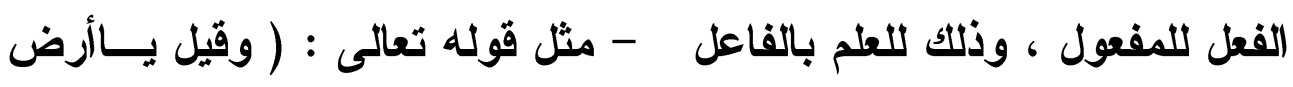

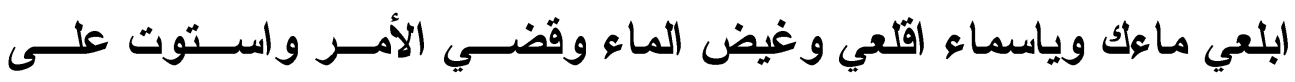

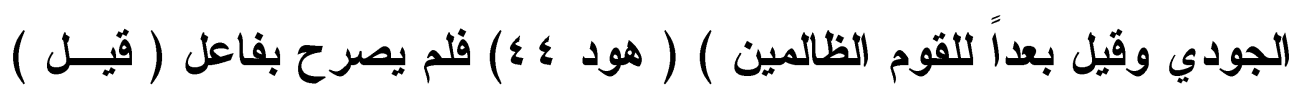
و( غيض ) و( قضي ) ، وذلك " تنبيهاً على أن تلك الأمور العظام لا يتصور

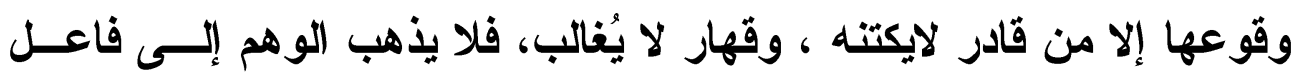

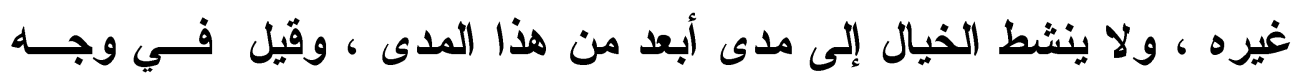

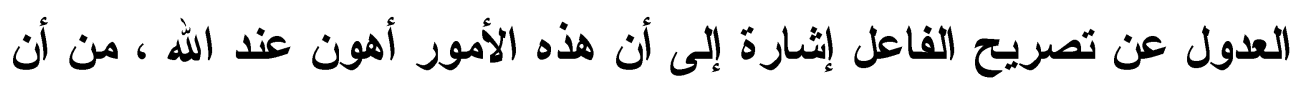

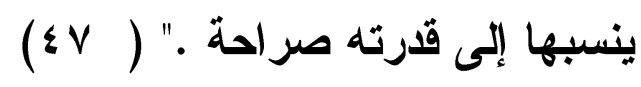
هذف المبتدأ :

- في قوله تعالى : ( الر كتاب أحكمت آياته ثم فصلت من لان حكيم

خبير ) ( هود ( )

( كتاب ) خبر لمبتدأ محذوف والتقدير ( هذا كتاب ). $\dot{9}$

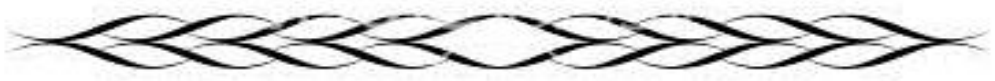




\section{الترقير الدولخ \\ ISSN 2356-9050}

- وقوله تعالى : (ولقد جاءت رسلنا إبراهيم بالبشرى قالوا ســلاماً

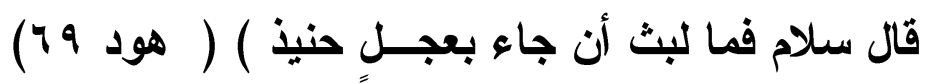
في الآية حذف للمبتدأ ، في قوله تعالى ( قال سلام ) ، أي أمسـري وأمركم سلام ، أو مبتدأ مدذف الخبر ، أي عليكم سلام .

- وحذف المبتدأ بعد نعم وبئس ، ويتمثل ذلك فــي قولــهـ تعـالى:

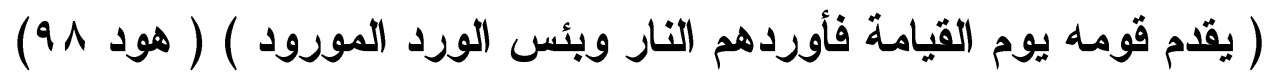
في قوله تعالى ( بئس الورد ) المبتدأ محذوف وجوبــاً ، والتقــدير ( هو المورود ).

- وقوله تعالى : ( وأتبعوا في هذه لعنة ويوم القيامة بئس الرفـــ

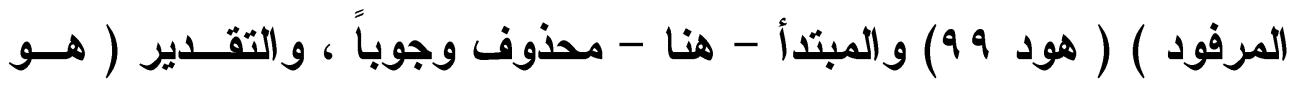

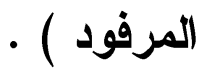
حذف الخبر :

- ومن ذلك قوله تعالى : ( قالو ا يا شعيب ما نفقه كثيراً مما تقـول

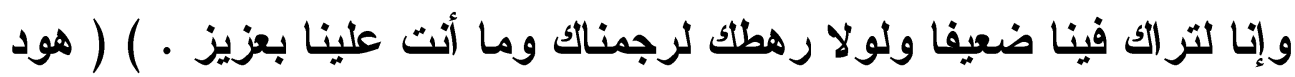
19) ويقدر الخبر المحذوف ( موجود ) أو ( حاصل ) . - وقوله تعالى : ( يوم يأتِ لا تكلم نفس إلا بإذنــهـه فــنهم شـــي وسعيد ) ( هود ه ـ 1) أي منهم سعـيد حذف الخبر لالاية الأول عليه. 
- ومن ذللك قوله تعالى : ( ولئن أخرنا عنهم العذاب إلى أمة معدودة

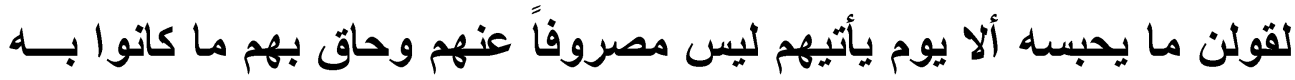

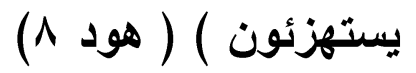

حذف المضاف في قوله ( إلى أمة ) ، أي إلى مجئ أمة .

- وقوله تعالى:( مثل الفريقين كالأعمى والأصم والبصير والســيع

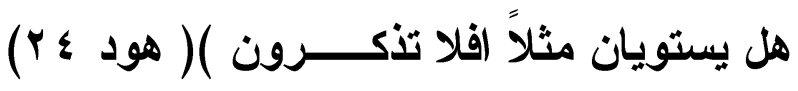
أي كمثل الأعمى وكمثل السميع.

\section{حذف الاضاف إليه:}

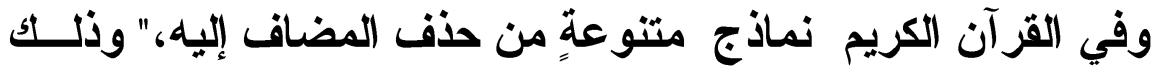

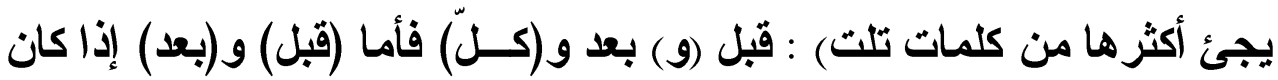

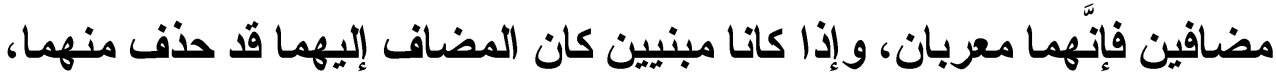

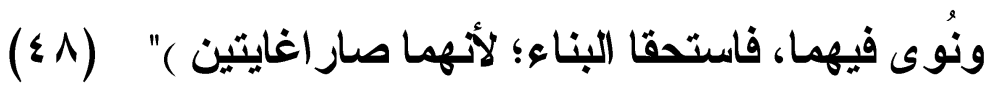
- ومثاله قوله تعالى : ( حتى إذا جاء أمرنا وفار التنور قلتنا احمـل فيها من كل زوجبن اثنين وأهلك إلا من سبق عليه القول ومن آمن معله إلا الا

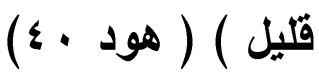
في الآية حذف المضاف إليه بعد ( كل ) ، والتقدير (بعد كل شــئ زوجين ).

- وقوله تعالى:(ونادى نوح ربه فقال رب إن ابني مسن أهـــي وإن وعدك الحق وأنت أحكم الحاكمين )( هود ه ؛ ) 


\section{الترقير الدولخ \\ ISSN 2356-9050}

في الآية حذف المضاف إليه ياء المتكلم بعد ( رب ) ، والتقدير ( فقال

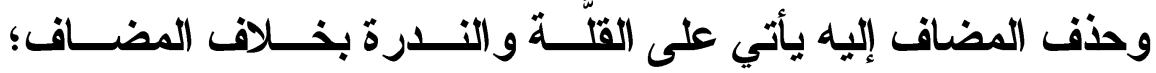

"و التقرقة بين المضاف نفسه، والمضاف إليه في الحذف حيث كـــان حـــف

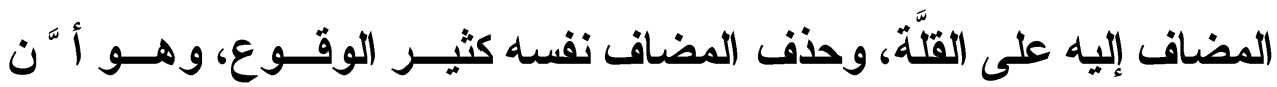

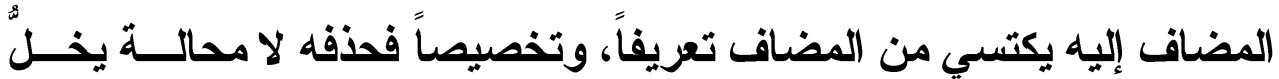

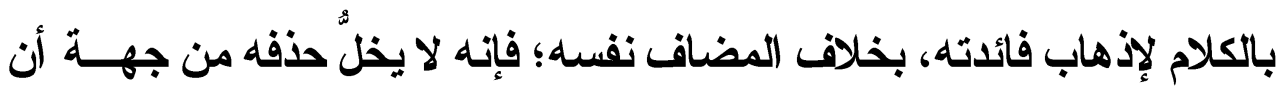
المضاف إليه يذ هب بفائدته، ويقوم مقامه." ( 9 ـ )

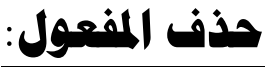

ويعد حذف المفعول من اللطائف ، ما يفوق غيره ، كحذف المبتـــأ مثنلاً ، ومن حذف المفعول به :

- قوله تعالى : ( قال ياقوم أرأيتم إن كنت علــى بينــة مــن ربــي وأتاني رحمة من عنده فعميث عليكم أنلزمكموها وأنتم لها كارهون ) ( هود ^) مفعول ( أرأيتم ) محذوف ، والتقدير ( أرأيتم البينة ) . - وقوله تعالى:(إن تقول إلا اعتر الك بعض آلهتنا بسوء قـال إنـي أثهر الله واشهروا أني برئ مما تثركون) (هود ع ه )

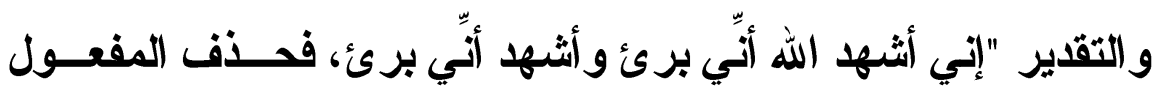
الأول على حد ضربت وضربني زيد" ( • ( ) 


\section{العلدول في سورة هود} دراسة أسلوبية

ومثلما يتمثل حذف المفردات في التنزيل، يتمثل كذلك حذف الجمل بما في ذلك من بلاغة وبيان .وبلاغة الأداء القرآن” ي في حذف الجمل عظيمة، ومن المطلوم" أن كَّفت الجمل له في البلاغة مدخل عظيم، وأكثر ما يرد فــي كتاب الله تعالى، وما ذاك إلا من أجل رسوخ قدمه، وظهور أثتـره، واثــتهـار علمه." (01) (01)

\section{ومن نماذج حذف البملة في سورة هود:}

- قوله تعالى : ( وإلى عاد أخاهم هوداً قال يـاقوم اعبـدوا الله ) (0. (0. )

- وقوله تعالى : ( وإلى ثمود أخاهم صالحا ) ( هود 1 آ) - وقوله تعالى : ( وإلى مدين أخاهم شعيبا ) ( هود ع ^)

و التقدير في الآيات السابقة (وأرســلنا إلــى عــاد أخــاهم هـودا ) و ( أرسلنا إلى ثمود أخاهم صالحا) و( أرسلنا إلى مدين أخاهم شعيبا) .

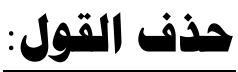

- ومن حذف القول في سورة هود قوله تعــالى : ( وأن اســتففروا

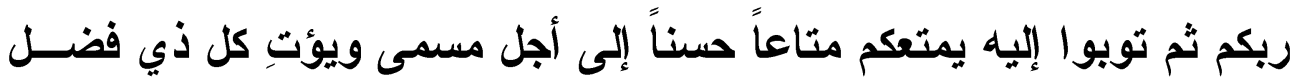

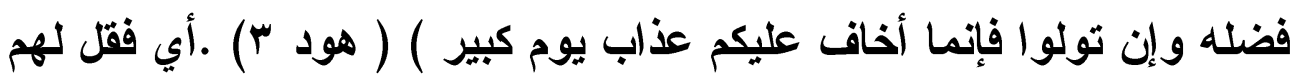

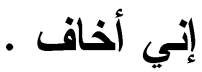

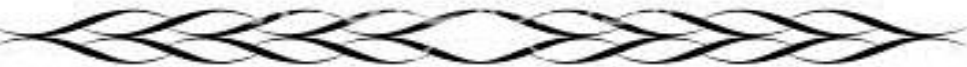




\section{الترقير الدوله \\ ISSN 2356-9050}

- وقوله تعالى : ( ولقد أرسلنا نوحاً إلى قومه إني لكم نذير مبين )

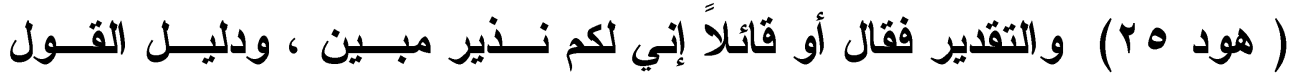
المحذوف كسر همزة ( إن ) ، على إرادة القول.

وقد تحذف جملة تامة من السياق، و المقصود بالجملة التامة" :الجملة

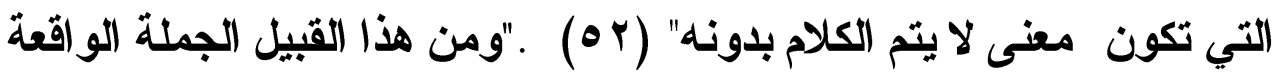
بعد (إذ) المتصلة بلفظتي (حين) و(يوم ).

- ومثال ذلك قوله تعالى : ( فلما جاء أمرنا نجينا صــالحا والـــين

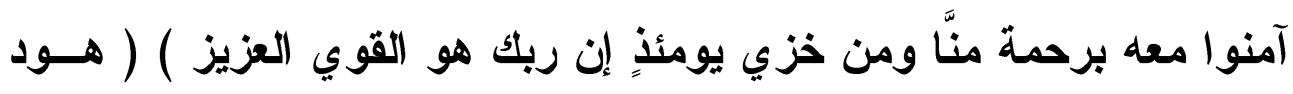

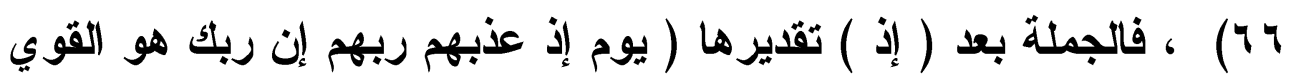

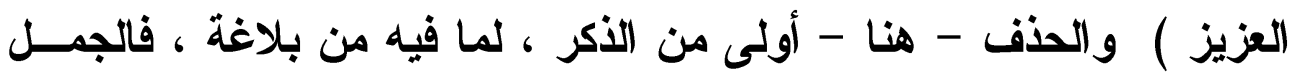

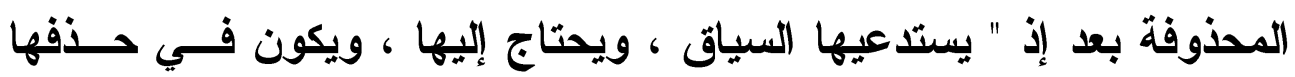

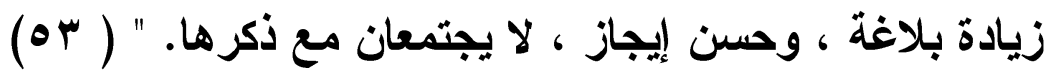

وفي الآية السابقة جائت ( إذ ) منونة تنوين عوض ، عـن جملــة

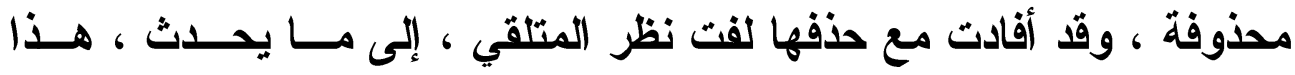

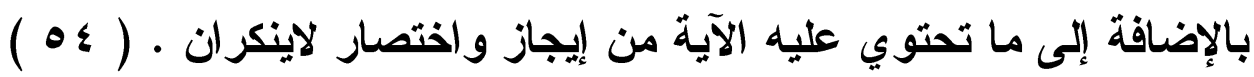
حذف الأجهبة :

ومن ذللك حذف جواب ( لو ) في قوله تعالى : ( قالوا لو أن لي بكم قوة أو آوي إلى ركن شديد ) ( هود ـ (1)

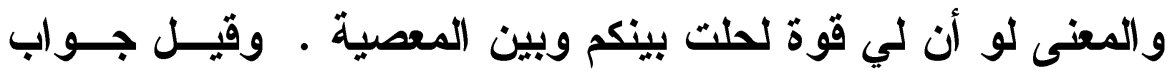

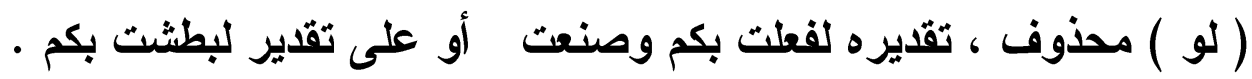




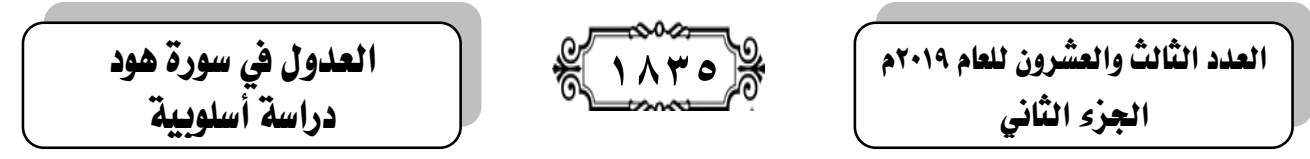

والسر في حنف جواب (لو) في النموذج السابق" :أنه " لماربطت

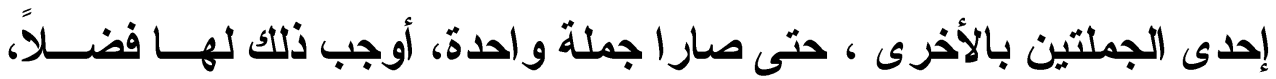

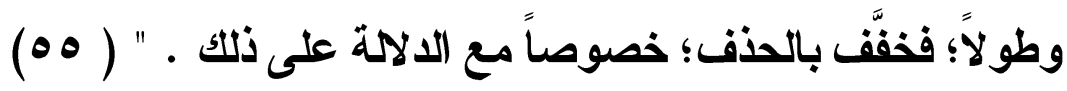
من خلال النماذج العابقة للحذف في سورة هود ، نجـــ أن العـدول

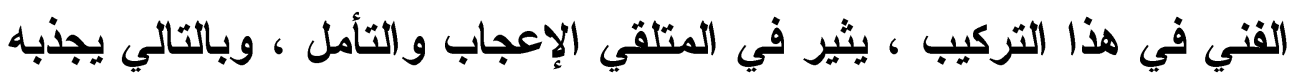

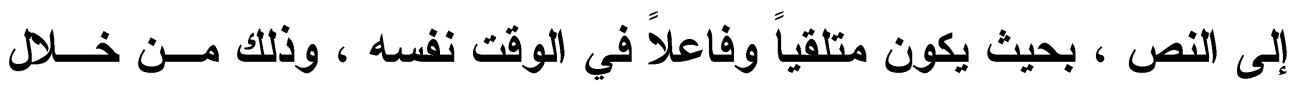

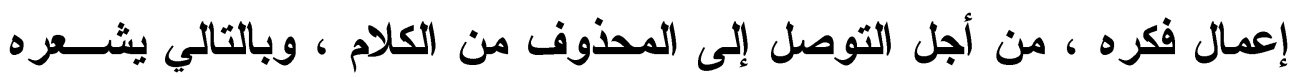

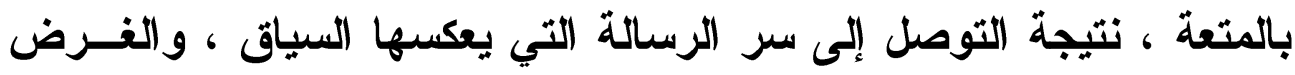

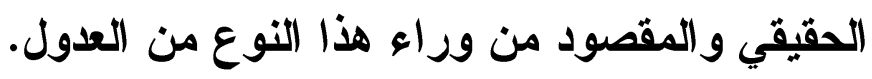

وقد اكتفينا بذكر الأمثلة التي تلل ، وبكل وضوح على وجود ظاهرة

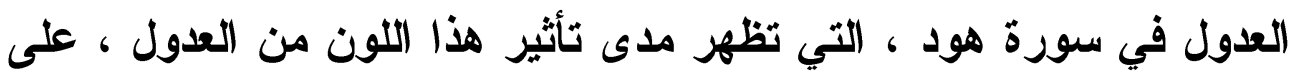
المتلقي ، وتحفزه على الاستمرار في الاستماع ، وبالتالي إيصال الرسائل.

ثالثاً

\section{التقديم والتأخير}

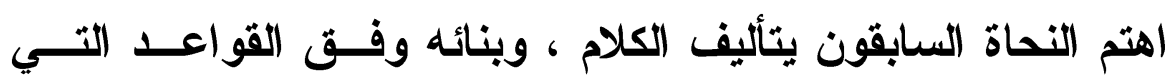

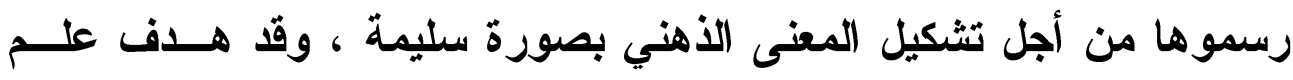

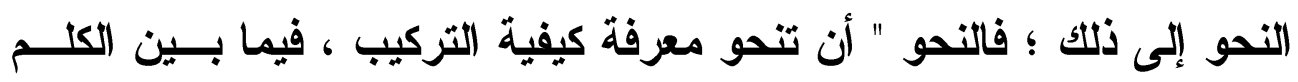

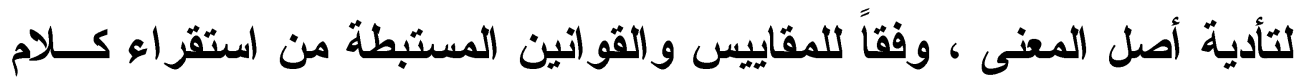

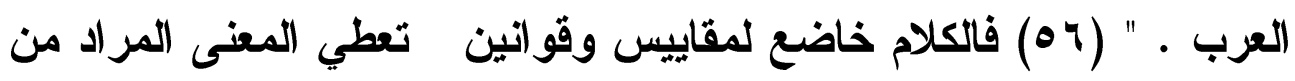

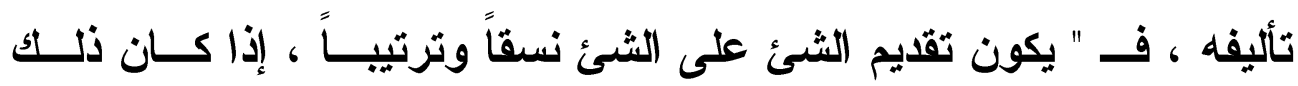

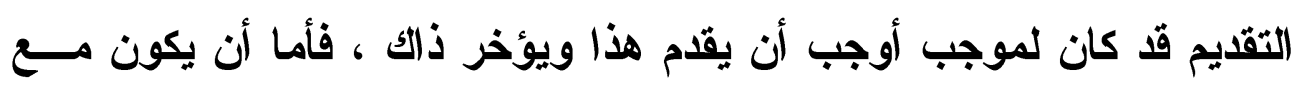

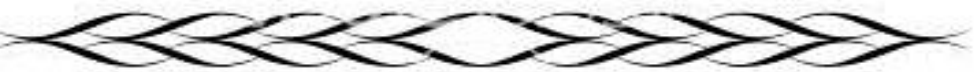




\section{الترقير الدولخ ISSN 2356-9050}

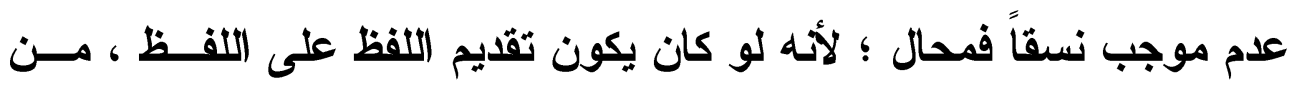

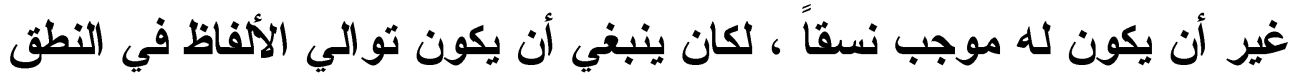

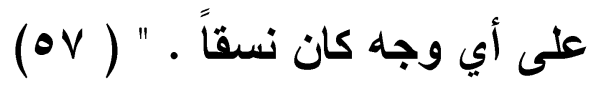

أي أن المتكلم مخير بين التر اكيب ، بحيث لا يانفه السمع ، ولا يمجه

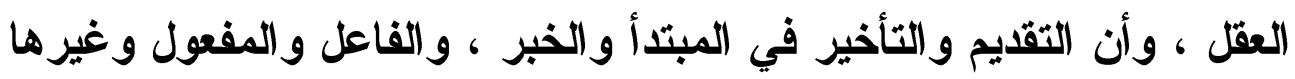

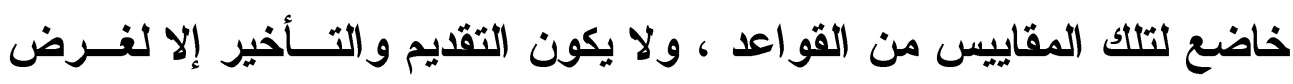

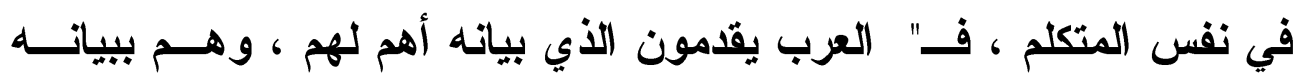

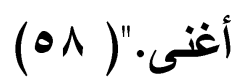

إن الموازنة بين التركيب النحوي ، المسـتند إلـــ قواعــــ اللغــة

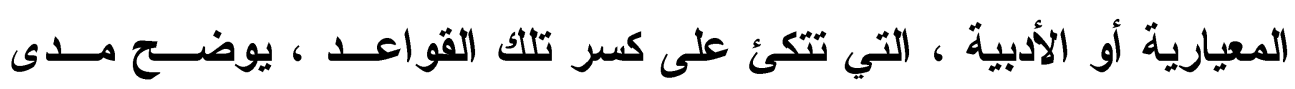

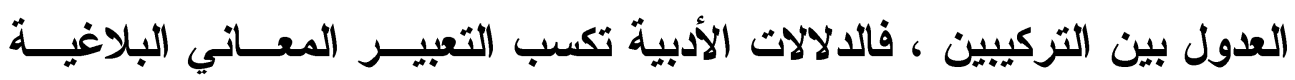

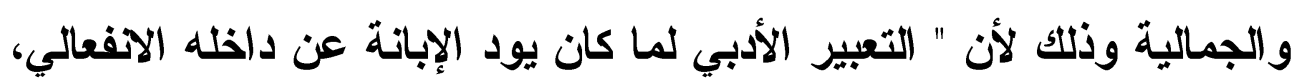

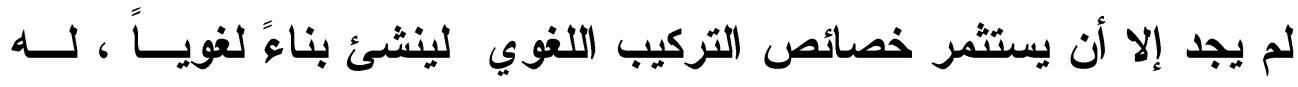

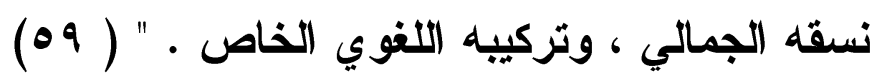

و التركيب اللغوي يحمل في طياته معاني ، لم تكن موجودة في الأصل

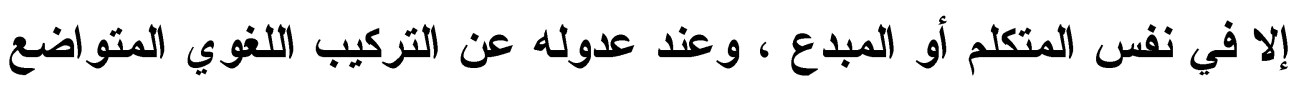

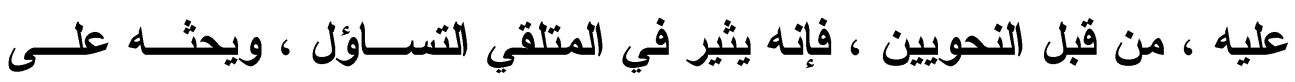

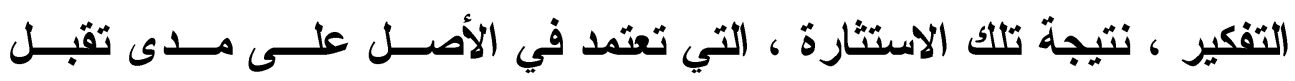
المتلقي لها.

ولكي يتمكن المتلقي من معرفة العدول الفني ، عليه أن يكون عارفاً

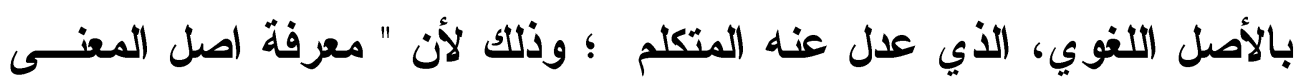




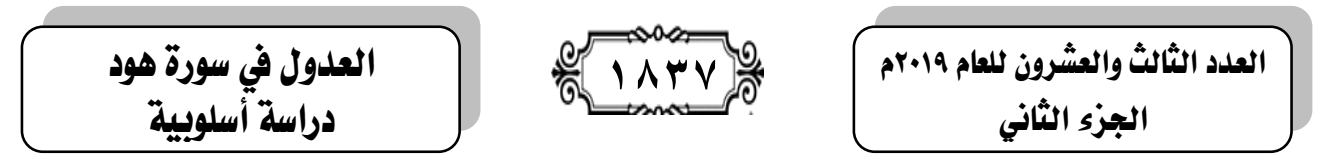

تبدو مهمة للبلاغي ، في ظل الكلام عن الكيفيات التي يطـابق بهــا اللفـــ

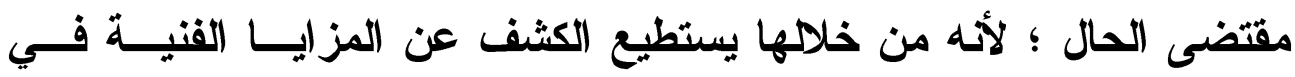
التركيب ، وبالتالي يستطيع أن يحد مواطن الصواب والخطأ البلاغي ، وفق لهن

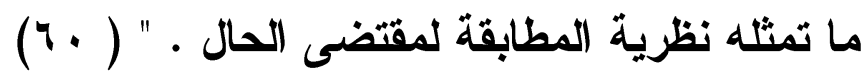
ولكن جمال التركيب الأدبي ليس مقصوراً على مخالفة الأصل ، فعلم

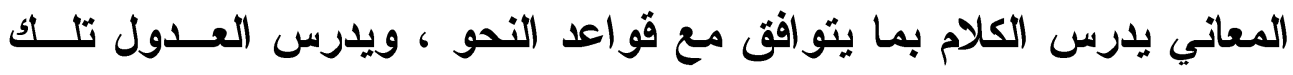

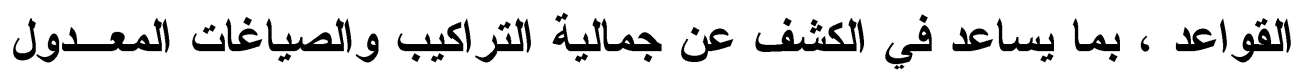
إليها.

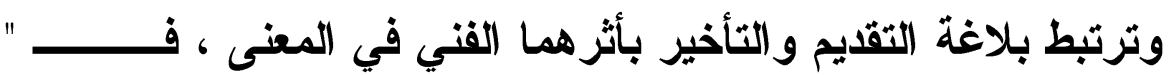

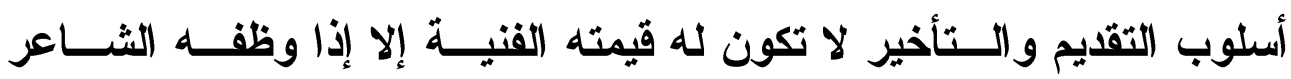

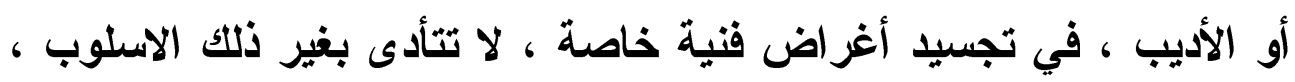

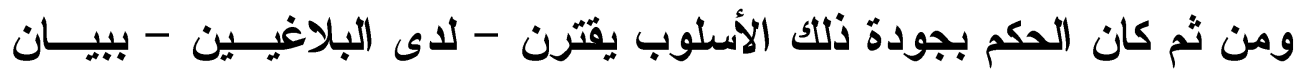

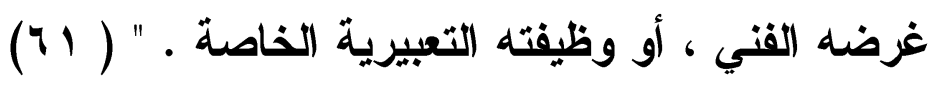

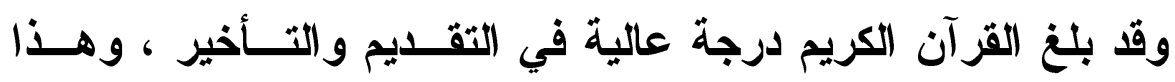

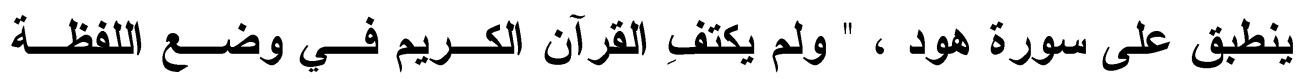

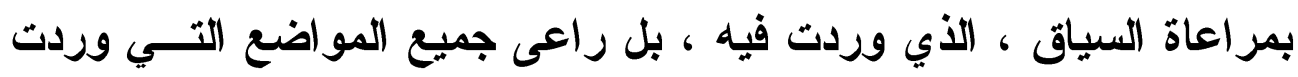

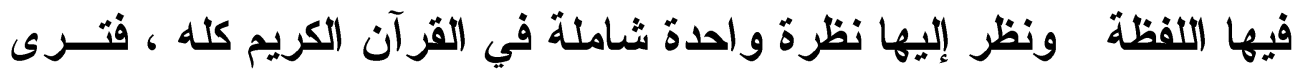

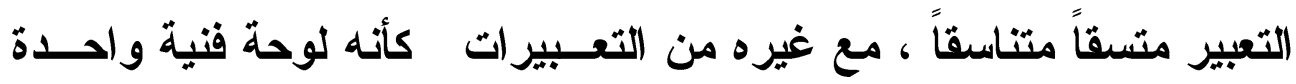

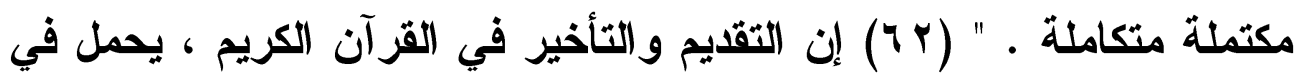

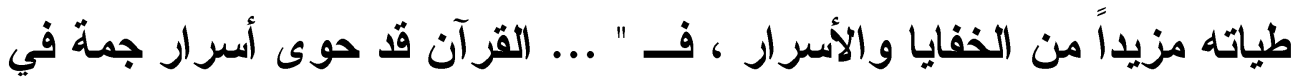

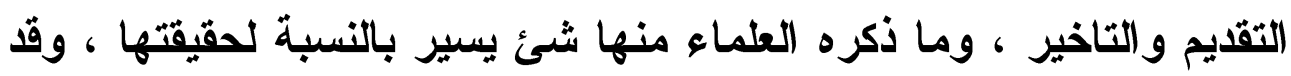

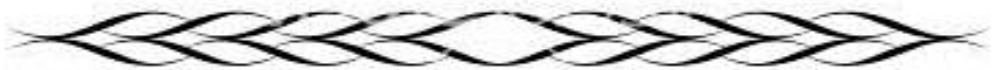




\section{الترقيم الدوله \\ ISSN 2356-9050}

يكون في الموضع الواحد أكثر من حكمة أو فائدة . " ( ب T)وفي سورة هود نماذج متنوعة للتقدبح و التأخير ؛ ومن ذلك:

التقديم للاختصاص:

ويعني " أن يكون المسند إليه معرفة ظاهرة بعد نفي • " (ع ؟) ومن

- قوله تعالى : ( قالو ا ياشعيب ما نفقه كثير اً مما تقول وإنا لنــــر أك فينا ضعيفاً ولولا رهطك لرجمناك وما أتث علينا بعزيز قال : ياقوم أرهطـي

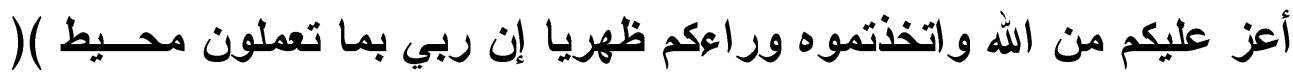
(qr-q) هود

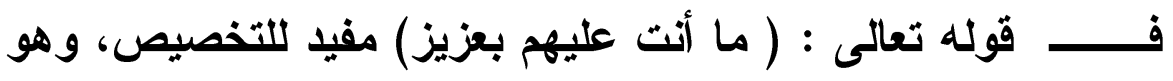

قصر نفي العزة على شعيب ،وإثباتها لرهطه كأنهم قالوا : العزيــز علينــا ياشعيب رهطك لا أنت ، لكونهم من أهل دينتا ، ولألك قال - عليه الســلامفي جوابهم : أرهطي أعز عليكم من الله ـ أي من نبي الله. ( (7) - وقوله تعالى : ( إنتي لكم منه نذير وبشير ) ( هود r) فقدم ضميرهم فقال ( لكم معه ) ، أي خاصة ، لما كــان إرســاله صلى الله عليه وسلم - لأجل رحمة العالمين.(7 7)

- وقوله تعالى : ( ولله غيب الســـاوات والأرض ) ( هــود r I ) فقدم الخبر الظرف على الاختصاص.

- وقولله تعالى : ( هو أنشأكم من الأرض ) (هود (7) 


\section{العلدول في سورة هود دراسة أسلوبية}

की 1119

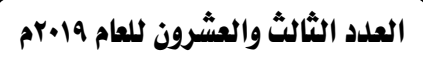
الجزء الثاني

و التقديم للمسند إليه لا يفيد الاختصاص فحسب ، وإنما بفيد التفخيم

$$
\text { والتأكيا • (TV) }
$$

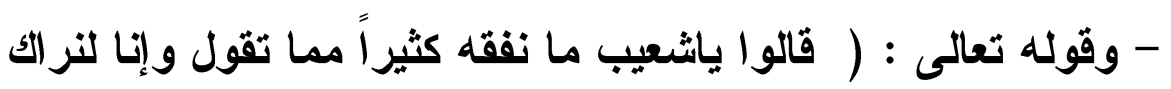

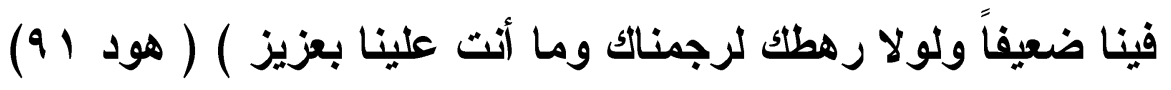

ودل التقديم على الاختصاص ، فالعزة منفية عـن شــيب - عليــه

السلام - مثبته لرهطه.

- وقوله تعالى : ( وحاق بهم ما كانوا به يستهزئون ) ( هود ^)

قدم الظرف ( به ) ، إثثارة إلى شدة إقبالهم على الهزء به ، حتـى

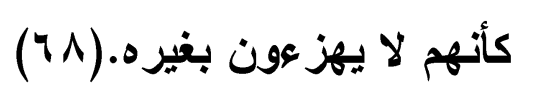

التقديم للاهتيمام:

- في قوله تعالى : ( ولئن أذقنا الإسان منا رحمة ) ( هود 9)

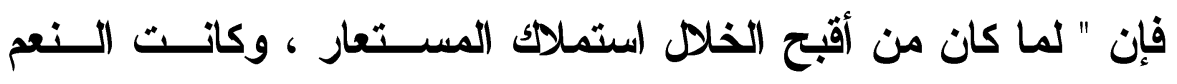

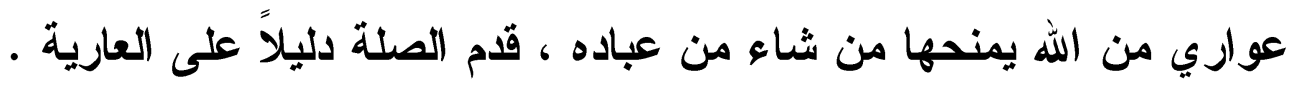

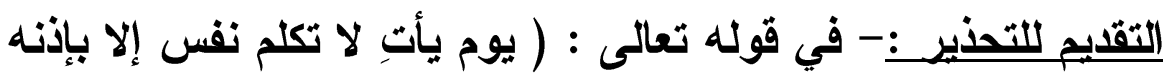

$$
\text { فمنهم شقي وسعيد ) ( هود ه. م. 1. ) }
$$

قام الثقي على السعيد ؛ لأن الكلام ورد في ســياق التــــير مــن

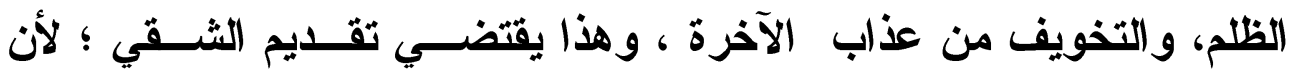

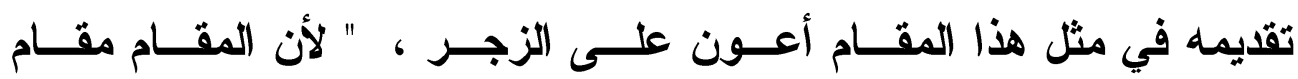
(v • (vنير

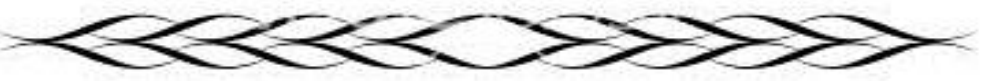




\section{الترقيم الدوله \\ ISSN 2356-9050}

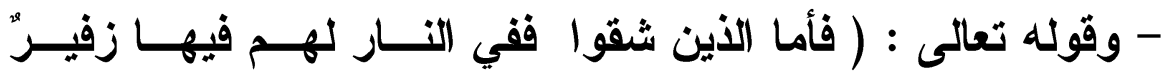

$$
\text { وشهيث ) ( هود } 1 \text { ( } 1 \text { ) }
$$

- وقوله تعالى : ( وأما الأين سعدوا ففي الجنة خالدين فيها مادامت السماوات والأرض ، إلا ما شاء ربك عطاءً غير مجذوذ ( هود 1 ، 1) فـ "قام أهل النار في الأكر على أهل الجنة ، ..... ، فإنه لما كــان الكلام مسوقاً في ذكر التخويف والتحذير وجاء على عقب قصص الأولين ، وما فعل الله بهم ، من التعذيب والتدميز ، كان الأليق أن يوصل الكلام ، بما يناسبه في المعنى ، وهو ذكر أهل النار ، فمن أجل ذلك قُّموا في الذكر على الهى

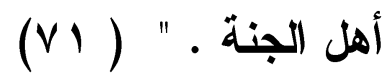

\section{التقديم للاسبق الزهني:}

- مثال ذللك قوله تعالى: ( وتمت كلمة ربك لأملأن جهنم من الجنـة

$$
\text { ومن الناس أجمعين ) ( هود } 19 \text { ) }
$$

$$
\text { قد الجن على الإس لأتهم أصل في البشر . (VY) }
$$

- وقوله تعالى : ( وامرأته قائمة فضحكت فبثرناها بإسحاق ومن

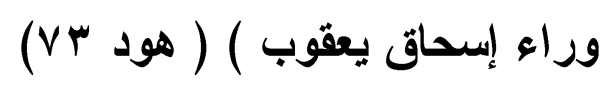

فإن يعقوب بن اسحاق ، والاليل على ذللك قولله - صــلى الله عليــاه وسلم - ( الكريم ابن الكريم ابن الكريم يوسف بن يعقوب ابن أسحاق بـن إير اهيم عليهم السلام ) (VT) والمقصود " فبثــرناه بإســحاق ، وقيـل : ضحكت أي حاضث بعد الكبر عند البشرى ، فعادت إلى عادات النساء مـن

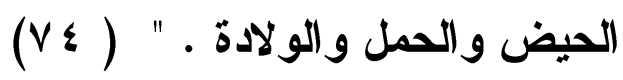




\section{العدول في سورة هود دراسة أسلوبية}

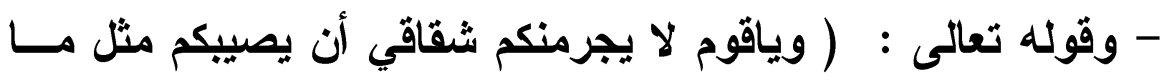

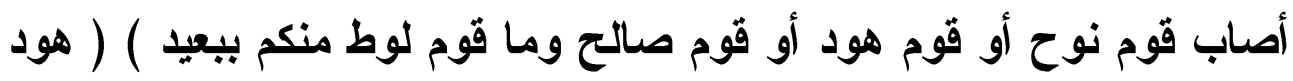

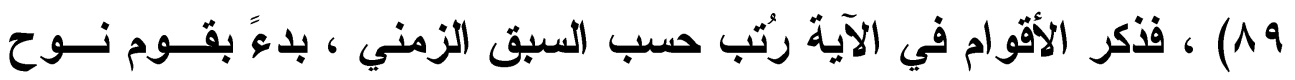

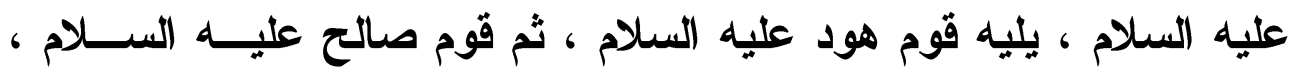

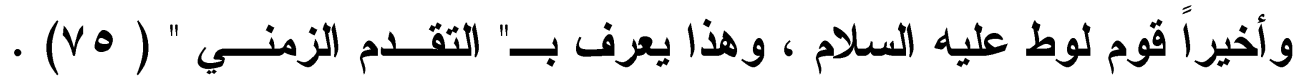

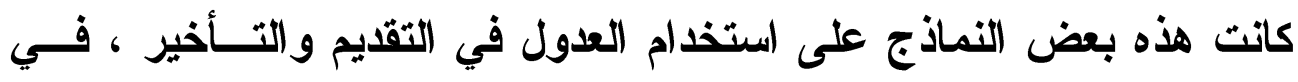

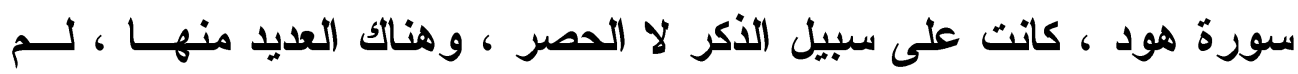

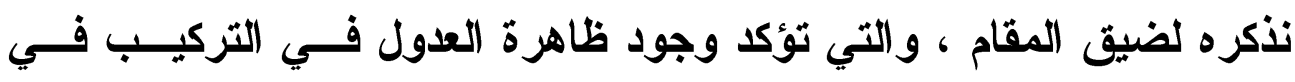

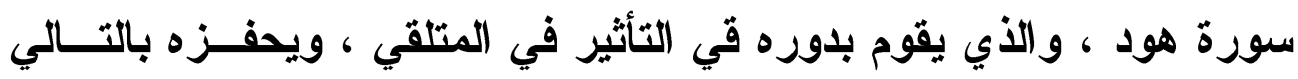
على التأمل والتدبر فيما يسمع أو يقرأ من التعبيرات و الصياغات الفنية.

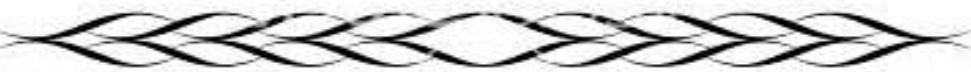




\section{الترقيم الدوله \\ ISSN 2356-9050}

[1 $11 \leqslant Y$,

حولية كلية اللفة العربية بجرجا

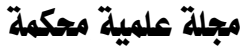

\section{المبــث الثاني}

\section{العـدول في الصور البلاغية}

\section{التشبييه}

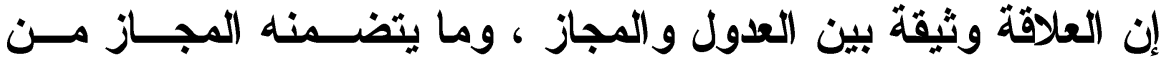

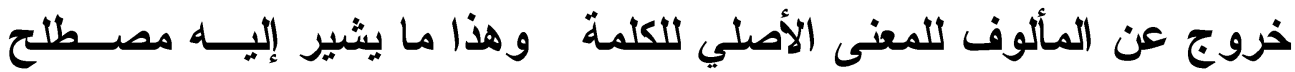

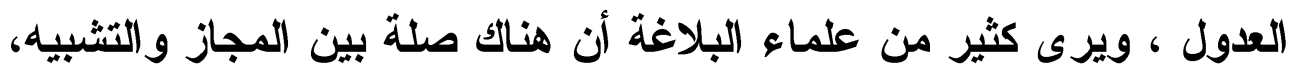

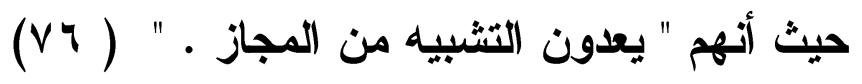

و التثبيه يقوم على مقارنة بين شيئين أو أكثر ، وهذه الصفة أكثر

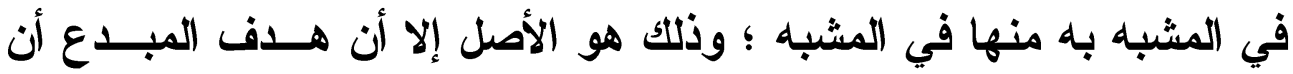

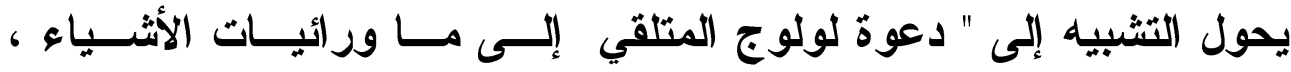

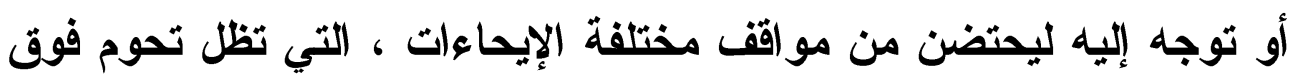

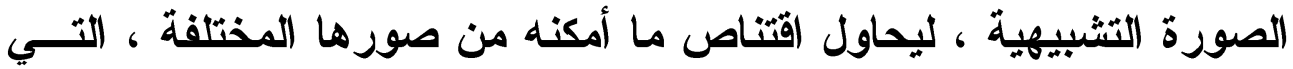

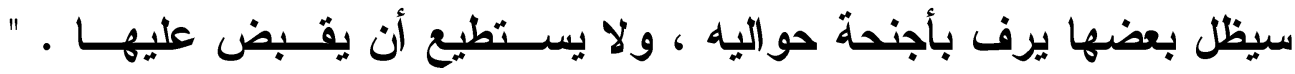
( $v \vee$ )

و التشبيه جزء من الصورة البيانية ، وهي إجراء عـدولي ، يعــــ

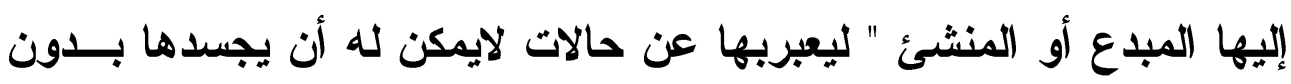

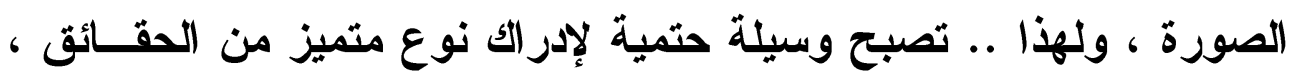

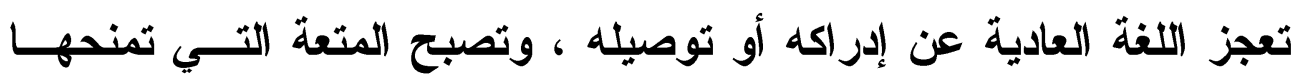




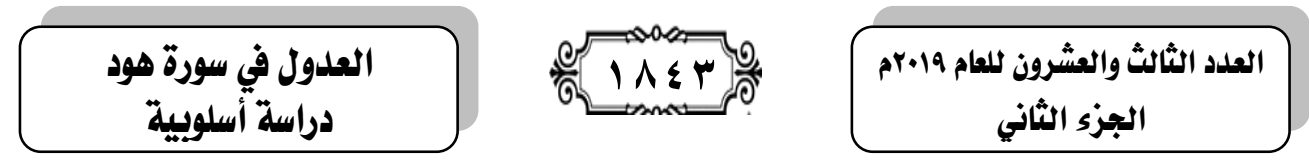

الصورة للمبدع قريبة الكثف ، و التعرف على جوانب خفية مسن التجربــة

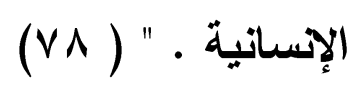

ويساعد التثبيه في تكوين الصورة البيانية ، التي تحدث في المتلقي

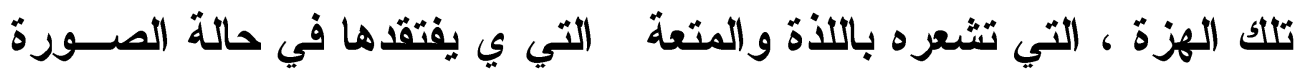

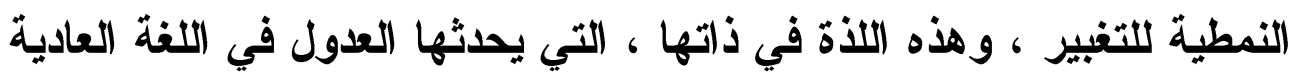

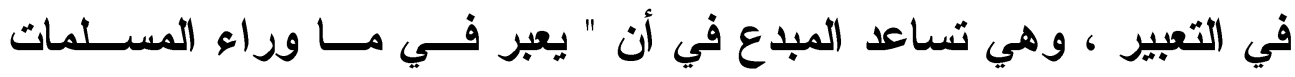

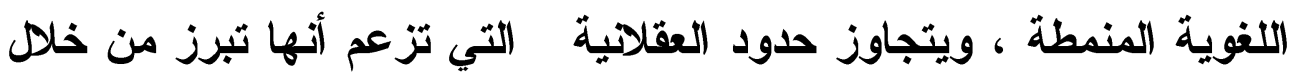

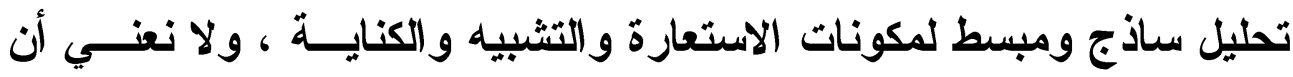
الخيال بديل العقل ، بل إنه يمر ، ولكنه يتجاوزه. " ( V9)

والتثبيهات في القرآن الكريم لا تقف عند مجرد تسجيل وجوه الثبه

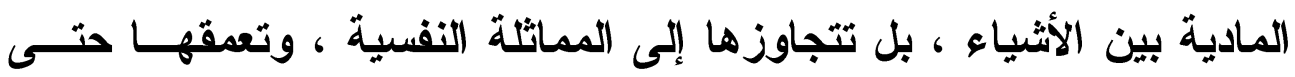

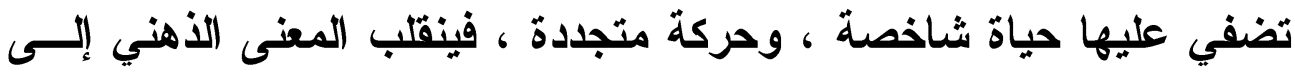

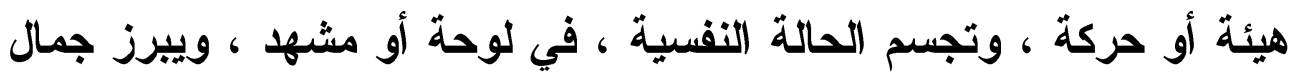

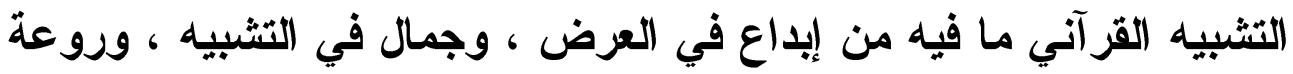
في النظم والتأليف وجرس في الألفاظ ، يلال على صورة معانيها.(• (^) كما نلمح - إلى جاتب ذللك - الاقة و التحديد فــي اختيـار الألفــاظ

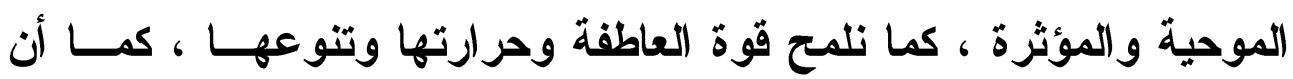

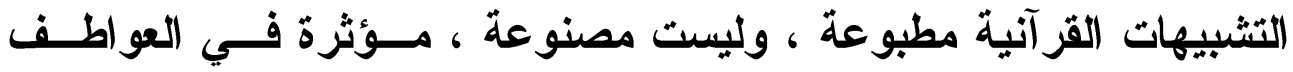

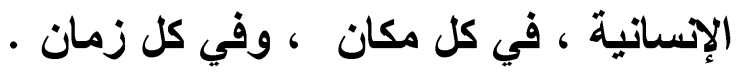




\section{الترقيم الدوله ISSN 2356-9050}

\section{ومن أمثئة التشبيهات فب القرآن الكريم في سورة هود:}

\section{- التشبيه التمثشيلي:}

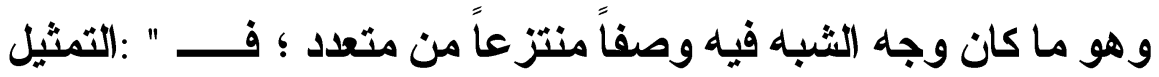

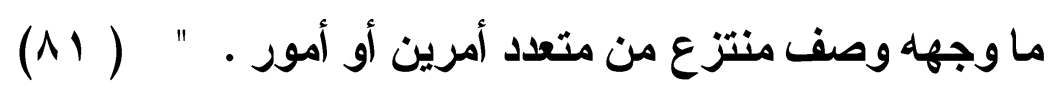

- ومنه قوله تعالى (ما كانوا يستطيعون السمع وما كانوا يبصرون )

هو تشبيه مركب بمركب، شبههم في فرط تصامهم عن استماع الحق،

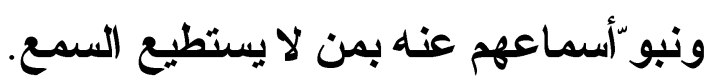

- وقوله تعالى:(مثل الفريقين كالأعمى والأصم والبصيز والسميع هل

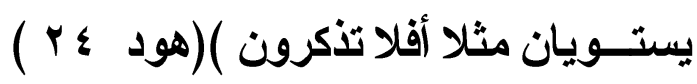
أي : مثل فريق المسلمين كالبصير والسميع ، ومثل فريق الكــافرين

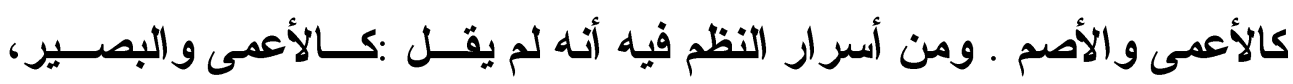
والأصم والسميع، على وجه المطابقة ليصح السؤال على قصد التوبيخ. ويُستفاد من هذا التشبيه تقبيح المشبه ، والتنفير منه ، ذفي حــال الكفار ، وتزيين المشبه ، والترغيب فيه في حـال المــؤمنين ، مراعــاة

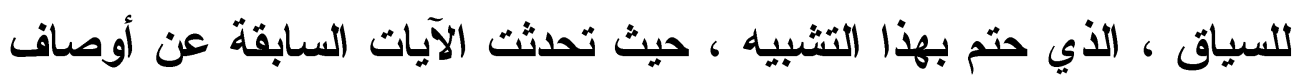
الكافرين ، ثم أوصاف المؤمنين فجاء الترتيب ملائماً للسياق . - وقوله تهالى: (أفمن كان على بينةٍ من ربه ويتلوه شــاهدٌ منـــهـ

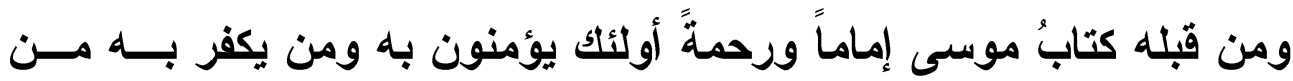




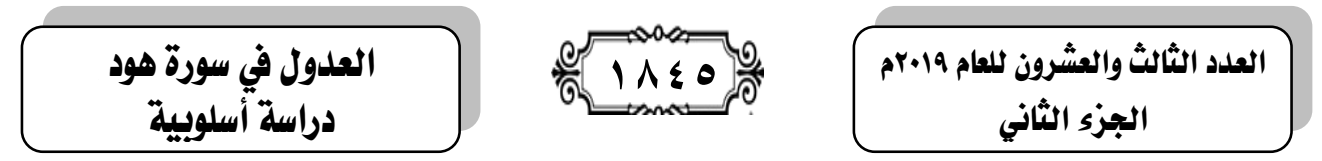

الأحز اب فالنار موعده فلا تلك في مرية منه إنه الحق من ربك ولكـن أكثــر

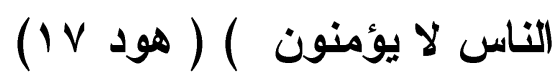

هذا التشبيه قصد به الإقرار بالقر آن الكريم ، فالمتأمسل فــي الآيــة

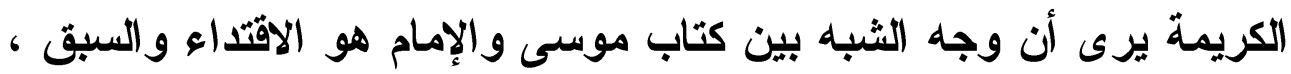
إذ يقتلى بالتوراة ، كما يقتدى بالإمام ، وعرضه بيان حال كتاب موسـى -

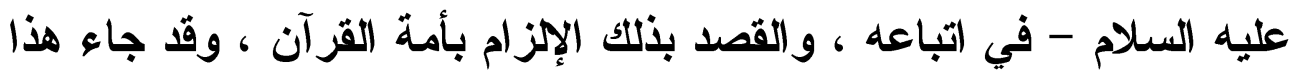

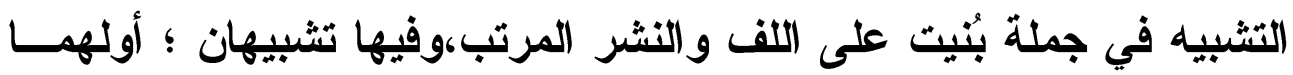

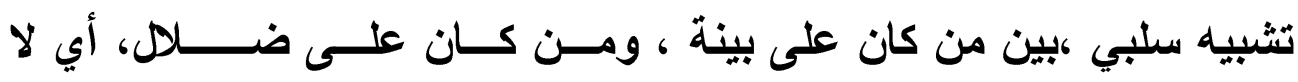

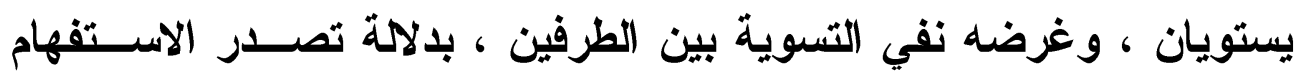

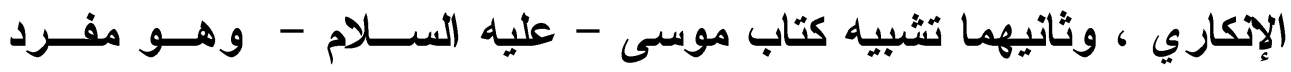

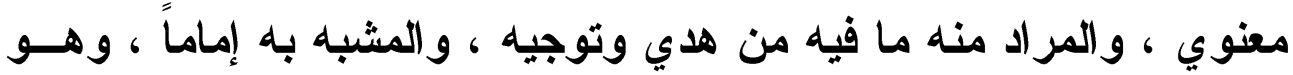

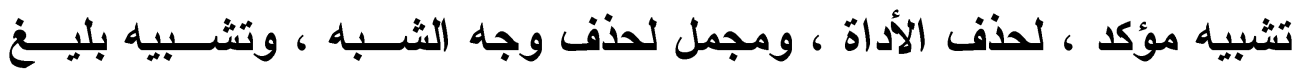

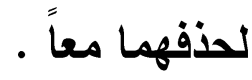

- وقوله تعالى : ( وهي تجري بهم في موجٍ كالجبال ونــادى نــوح

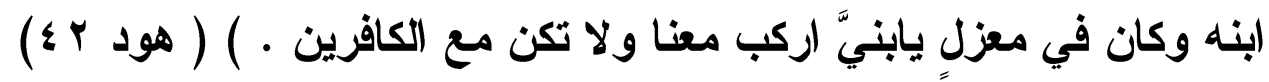
جاعت الآية في أمر نجاة نوح - عليه السلام - ومسن معسه فــي

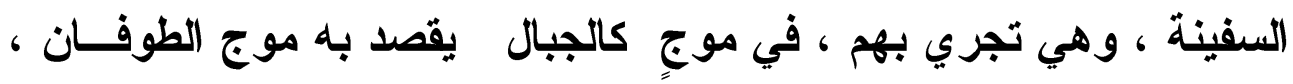

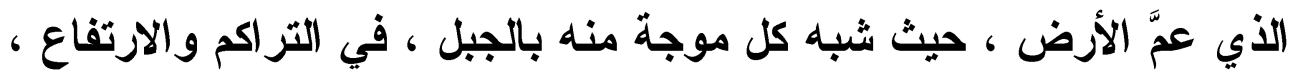

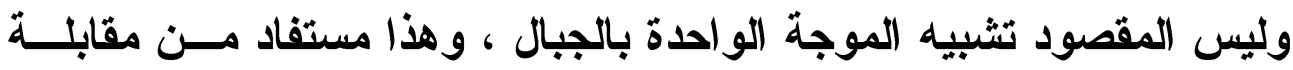

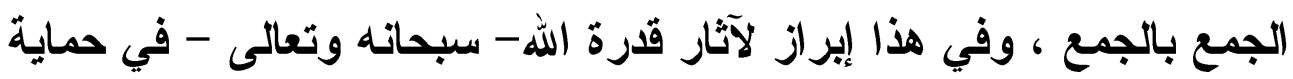

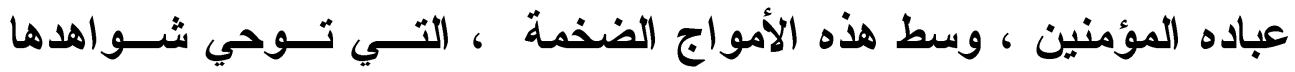

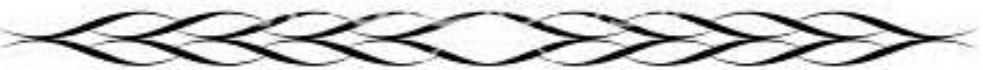


الترقير الدولخ ISSN 2356-9050 $\lim _{0} 11 \leq 7$
حولية كلية اللفة العربية بجرجا مجلة علمية محكمة

بالهلاك المبين كما تبرز آثار هذا الكائن الصغير ، الأني صــنعه نــوح عليه السلام - ونلمع فيه- أيضاًَ- " عظمة الأمر من حال الماء ، وتغطيتــه لسطح الأرض ، ومن ملابسة الرياح له ، ومن ذكر الاعتبار بجري السفينة، في هذه الأهوال ، وناب لفظه ، مع اختصاره عن شرح كثير • " (Y (A) ، كما نلمع فيه - أيضاً - شدة الهول الأي حل بالناس ، وبشــاعته فــي واقعـة الطوفان

\section{التشبيه الضشمني :}

وهو الأي يفهم من فحوى الكلام ، وسياق الحديث ، ولم يصرح فيه بأركان التشبيه ، ولم يأت على الطريقة المألوفة ، المتعارف عليهـــا ، فـيـي أسلوب التشبيه، وإنما يكون دليلاً لإثبات أمسـر غريسـب ، يُــدعى حصــوله أو تعليلاً لحكم عجيب ، ياعى إمكانه.

وينظر إلى التشبيه الضمني على أنه : " تشبيه لا يوضع فيه المشبه

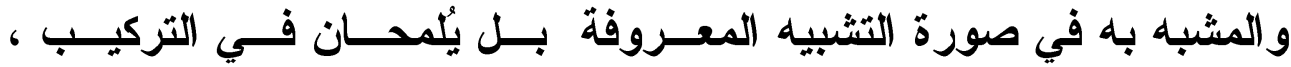
ويفهمان في المعنى ، وهذا النوع يُؤتى به ليفيد أن الحكم الذي أســند إلــى سي

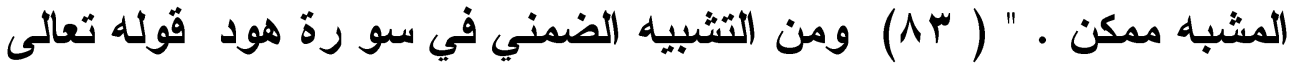
: ( أولئك لم يكونوا معجزين في الأرض وما كان لهـــــــن دون الله مــن أولياء يضاعف لهم الغذاب ما كانوا يستطيعون السمع وما كانوا يبصرون ) $(r \cdot s)$

حيث شبهرم من فرط تصامهم عن استماع الحق ، ونبو أســماعهم عنه ، بمن لا يستطيع السمع ، وهذا التثبيه أنفذ في النفوس والخــواطر ، 


\begin{tabular}{|c|c|c|}
\hline العدول في سورة هود & 1 $1 \wedge \varepsilon \vee ?$ & العدد الثالث والعشروز للعام 19+الجزم الثاني \\
\hline
\end{tabular}

لاكتفائه بالتلميح ، مما يزيد من قوة تأثيره ،ومن التشبيه المفــرد قـــــله

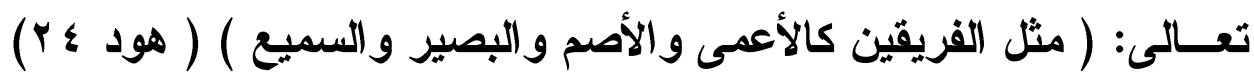
- وقوله تعالى : ( وهي تجري بهم في موج كالجبال ) ( هود ؛ ؟)

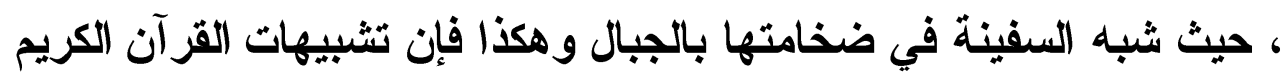
أياً كان وجهها صور بيانية، تتضح منها الحقائق الظاهرة، و المعاني العاطقة

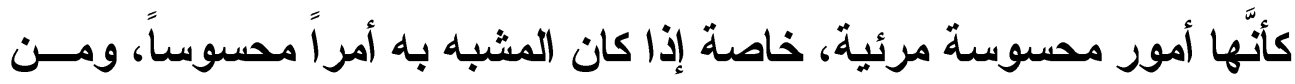

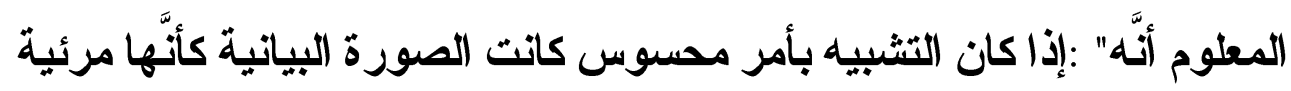

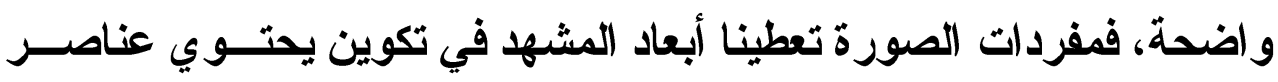

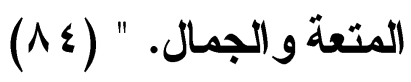

ثانيساً

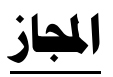

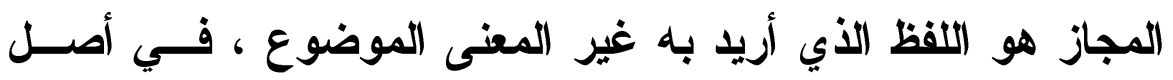

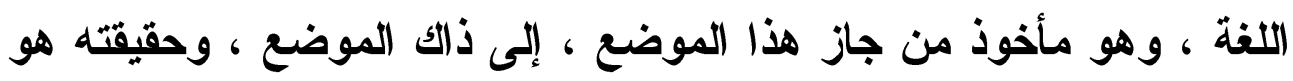

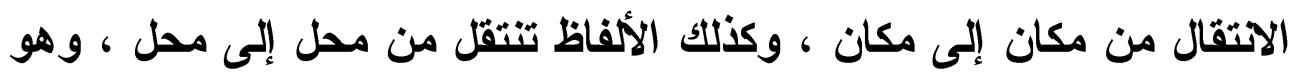

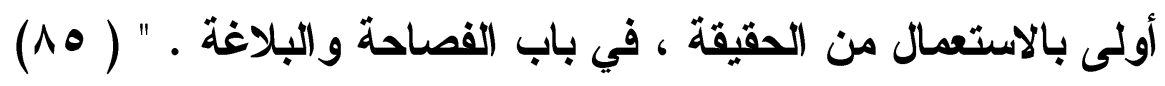
فإذا كان الأصل في الكلام هو الحقيقة عند النطق ، والحقيقة " إما

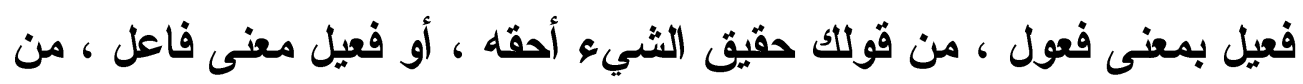

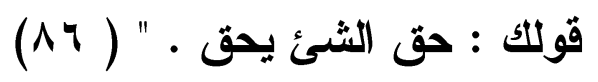
أما في معناها الاصطلاحي ، فهي تلال على ما " وضعت لله ، بحيــث

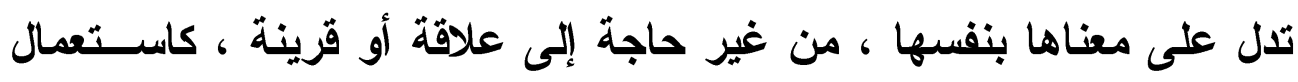

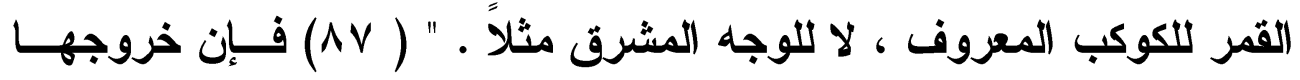




\section{الترقير الدولخ}

ISSN 2356-9050 $\frac{0}{111 \leqslant 1}$
حولية كلية اللفة العربية بجرجا مجلة علمية محكمة المية

عن المالوف ، المتواضع عليه ، وتجاوزها ذلكك ، من أجل الصورة البيانيــة

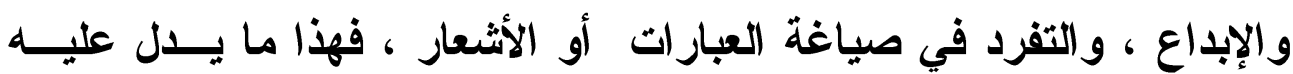

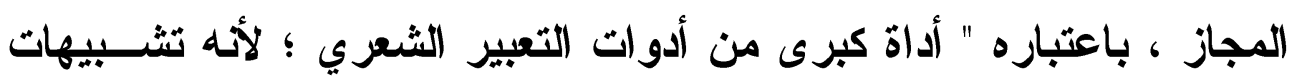
وأخيلة وصورة مستعارة ، و إثثار ات ترمز إلى الحقيقة المجردة ، بالأثــكال

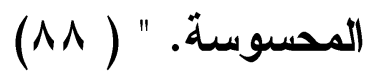

فـ " المجاز مفعل من جاز الثئ يجــوزه ، إذا تعـــاه ، وإذا عـــل

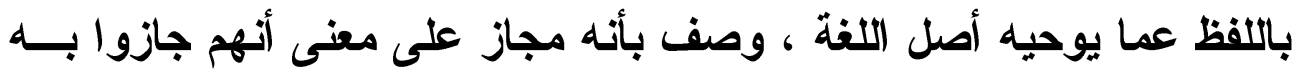

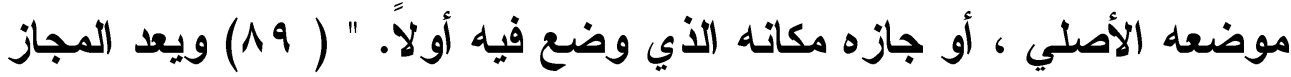

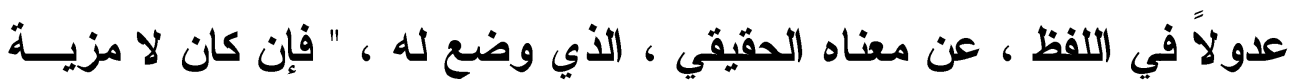

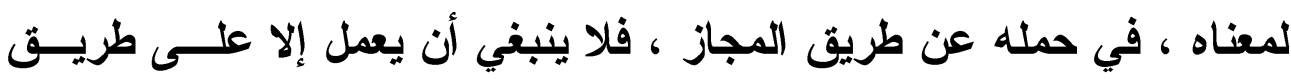

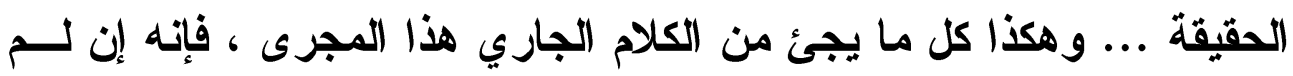

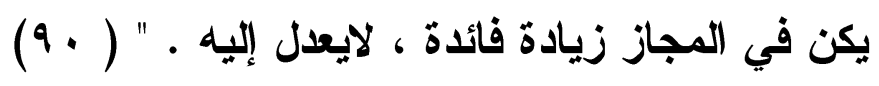

معنى هذا أن العدول عن الأصل هو في ذاته مزيـــة وتفاضـلـل فـــي

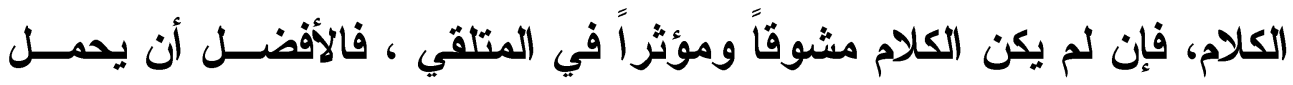

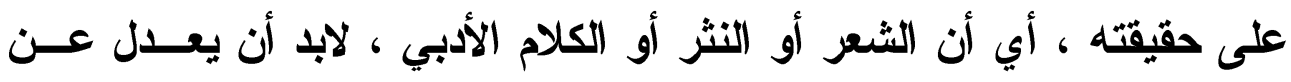

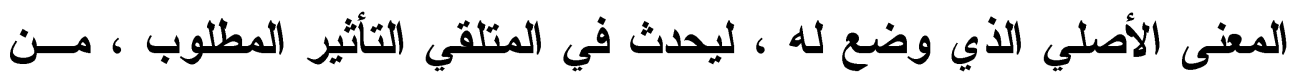

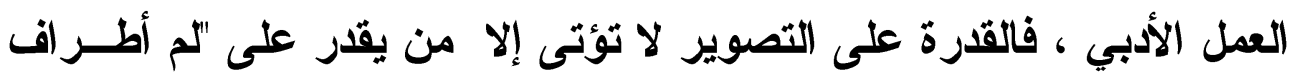

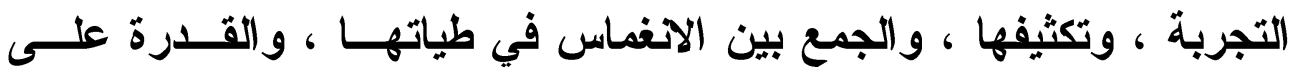

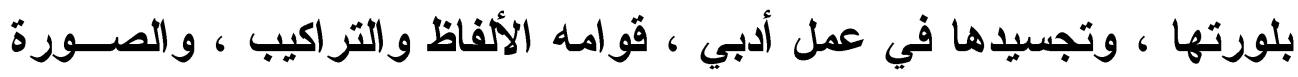

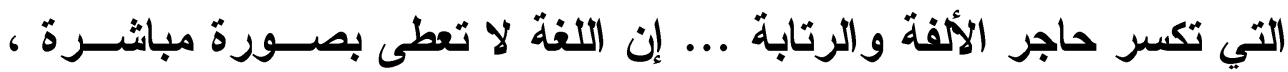

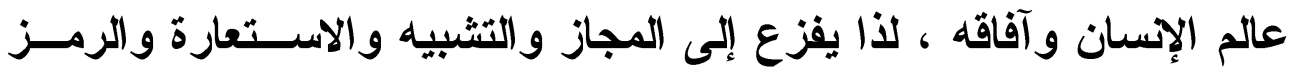
وسائر الأساليب الفنية للصورة وللتركيب الجمالي. " ( 

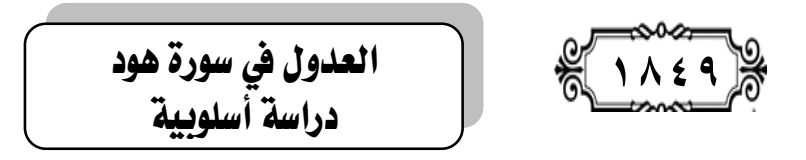

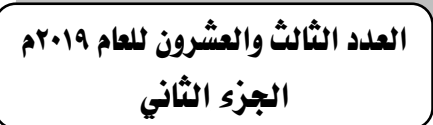

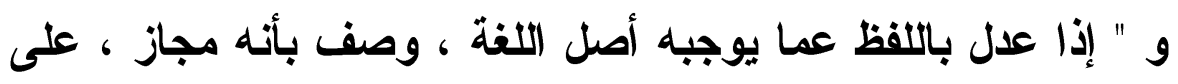

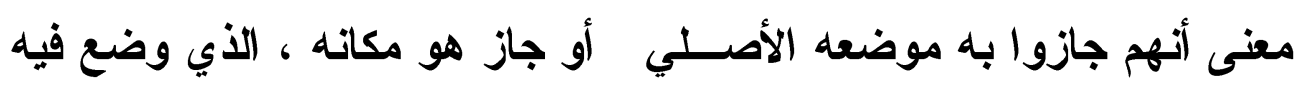

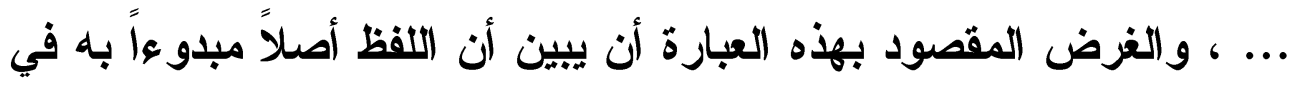

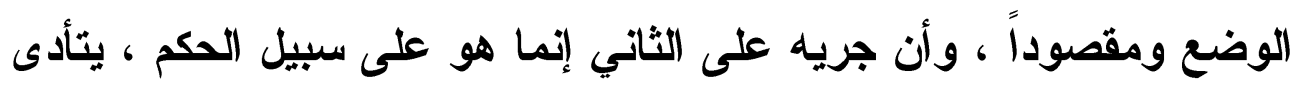

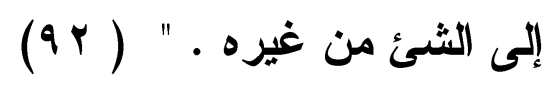

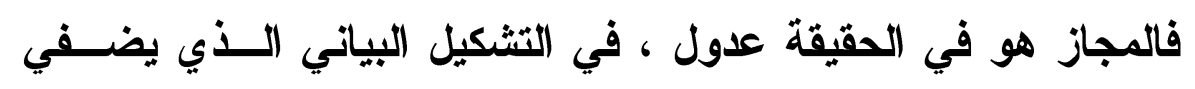

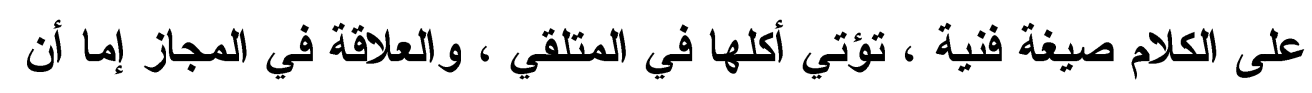

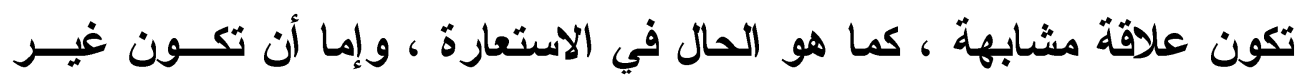

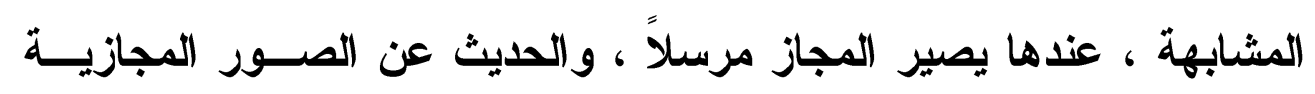

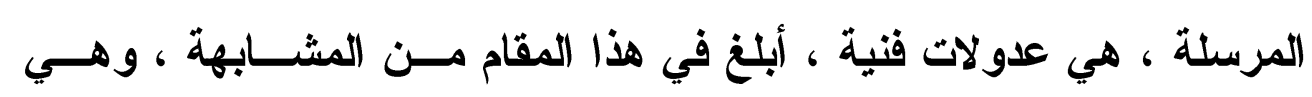

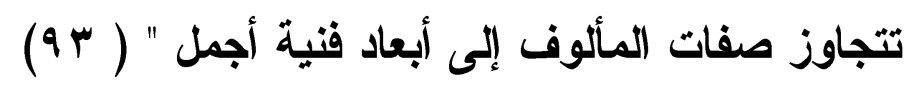
المجاز المرسل :

و " هو نوع من المجاز اللغوي ، وعلاقته غير المشابهة ، بمعنى أن

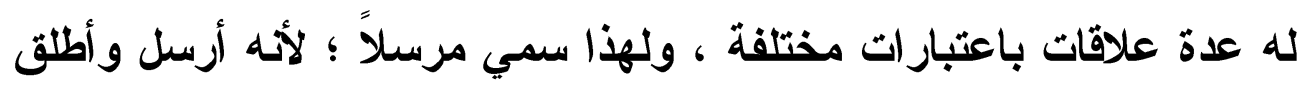

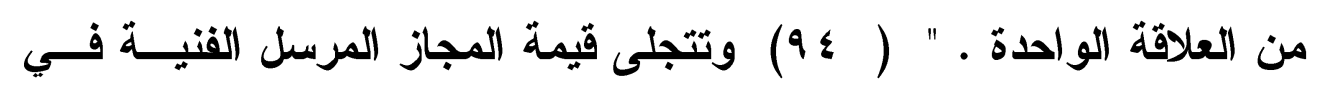

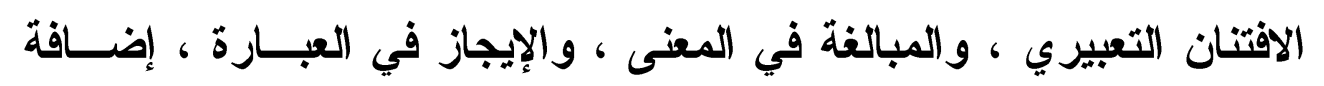

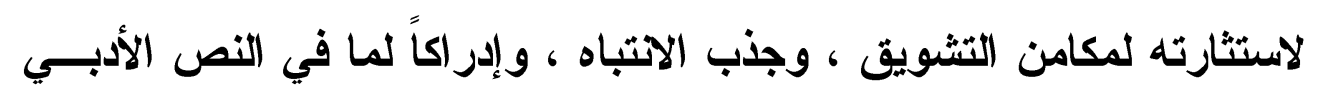

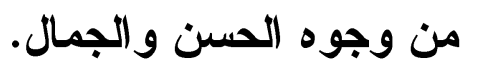




\section{الترقيم الدوله \\ ISSN 2356-9050}

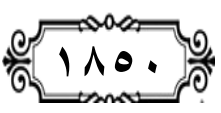

\section{وهن نهاذج المجاز المرسل في سورة هود:}

- قوله تعالى : ( ما كانوا يستطيعون السمع ) ( هود · ب)

فالمجاز المرسل في" إطلاق اسم السمع على قبول ذلك والعمل به ؛

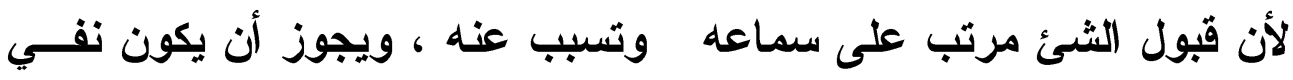

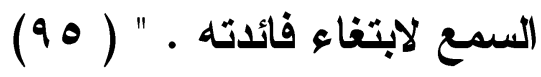

- وقوله تعالى:( قال لا عاصم اليوم من أمر الله إلا من رحم وحال

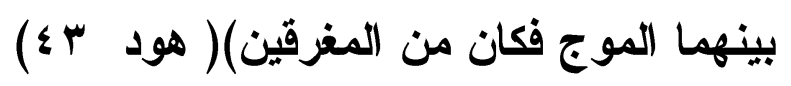

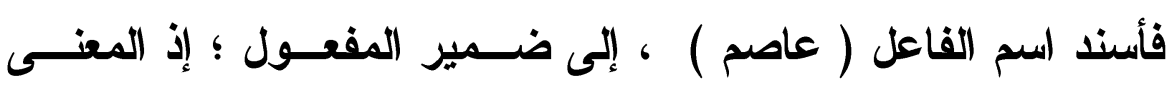

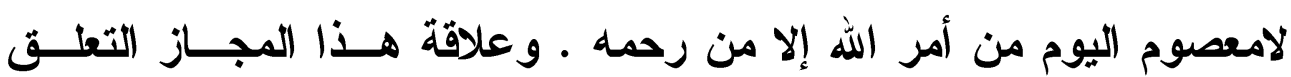

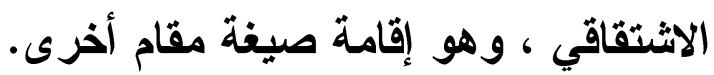

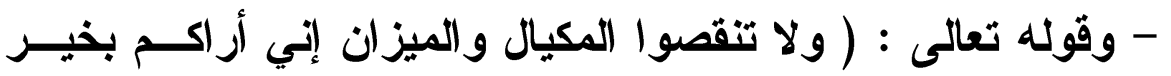

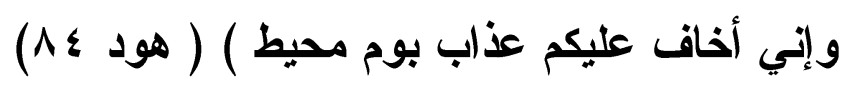

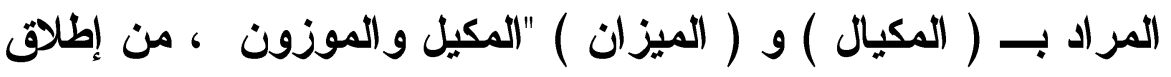

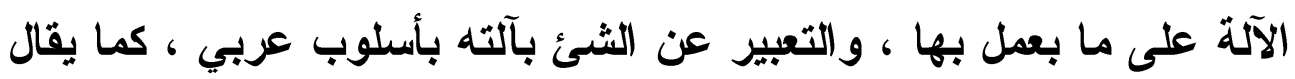

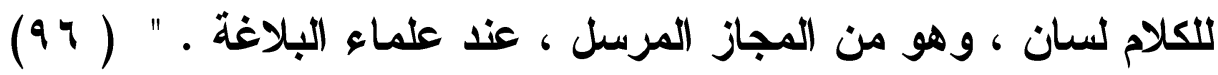
- وقوله نعالى : ( ألا إنهم يثنون صدورهم ليستخفون منه ألا حسين

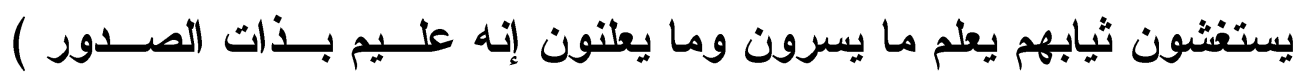
(هودن)

و الثـاهد في قوله تعالى : ( صدورهم ) ، وعلاقة المجاز المحليـة ،

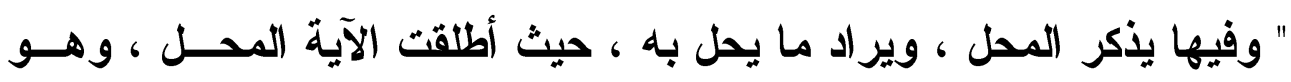




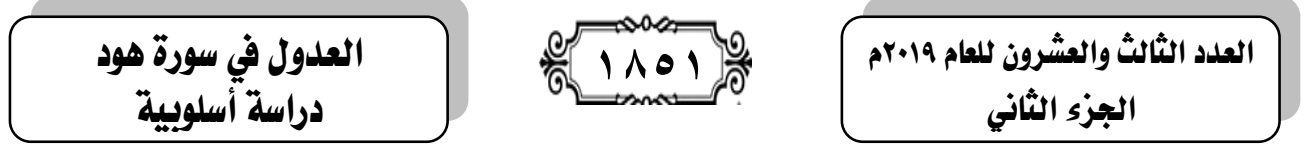

( الصدور ) ، وأرادت به ما يحل به ، وهو القلب، وفي هذا الأسلب تأكيــ

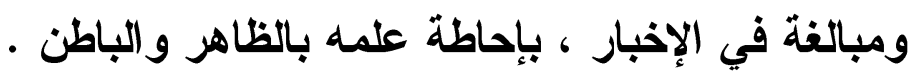

- وقوله تعالى : ( وقيل ياأرض ابلعي ماعك وياسماء اقلعي وغيض

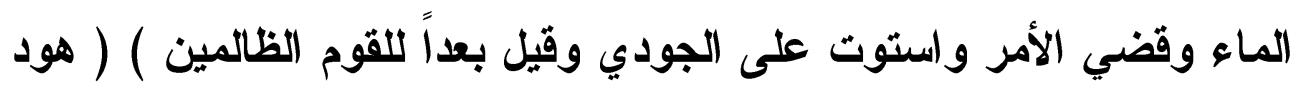

والحقيقة يامطر السماء اقلع ، والعلاقة في هذا المجــاز السـببية ؛

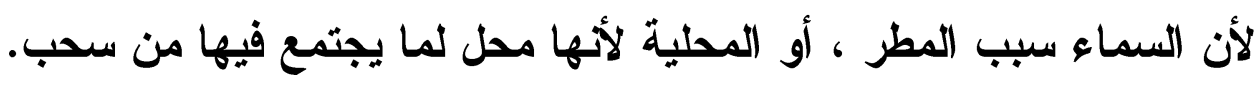

- وقوله: ( وتلكت عاد جدوا بآيات ربهم وعصوا رســله وا تبعـوا

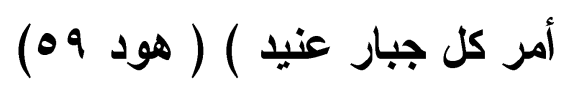

و المر اد به عصور رسولهم هود ، وفيه تفظيع لحالهم ، وبيـان أن

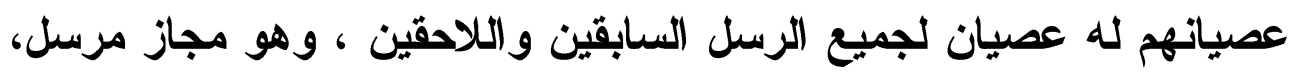

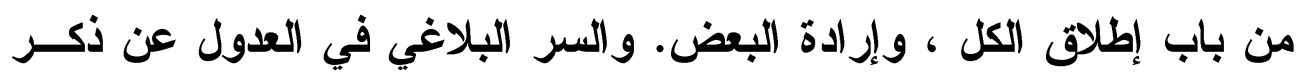

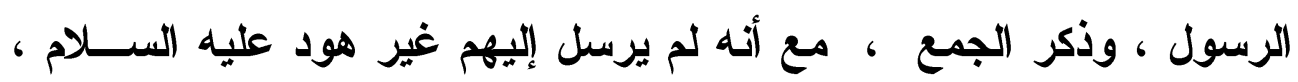

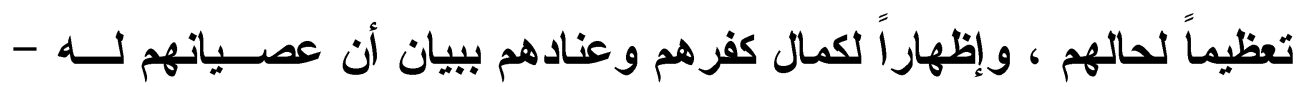
عليه السلام - عصياناً لجميع الرسل السابقين واللاحقين.

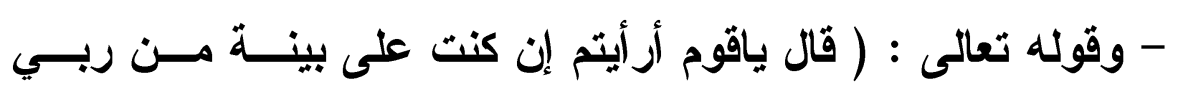

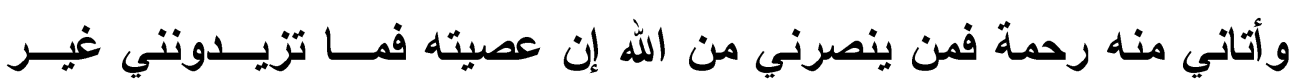

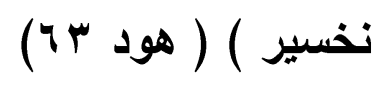

المجاز المرسل في كلمة ( رحمة ) ، مجاز مرسل علاقته المسببية ،

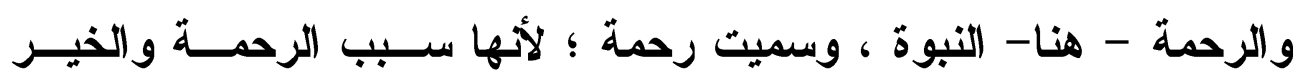
(9V) (للمؤمنين، 


\section{الترقيم الدوله \\ ISSN 2356-9050}

فالعلاقة في الآية المسبية ؛ حيث أطلقت الآية السبب ، وهو كلــة

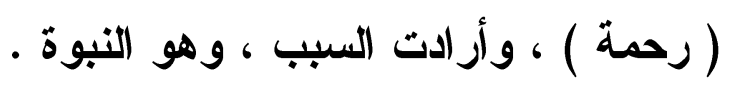

- وقوله نعالى : ( فلولا كان من القرون من قبلكم أولو بقية ينهون

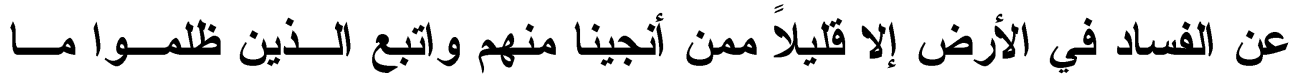

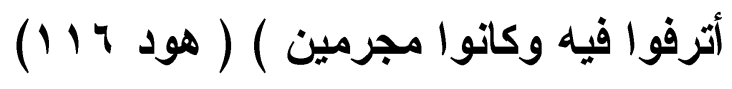

فالقزرون مجاز ، حيث أطلقت، وأريد من كان يعيش فيها ، ويــوحي

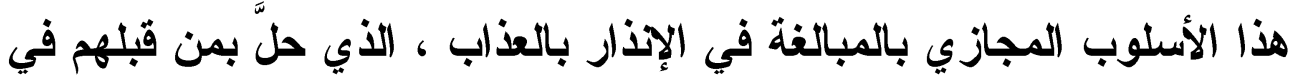

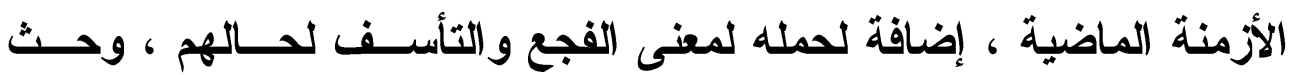
هؤلاء الأقو ام للاعتبار من مصيرهم .

- وقوله تعالى : ( وجاءه قومه يُهرعون إليـهـ ومسـن قبـلن كـانوا

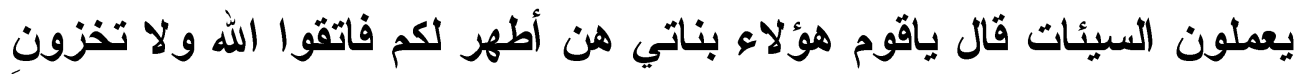

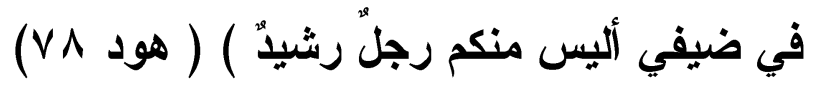

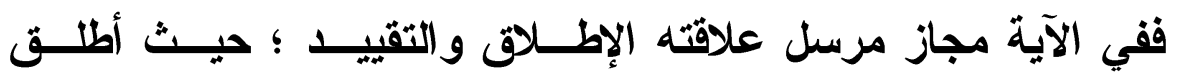

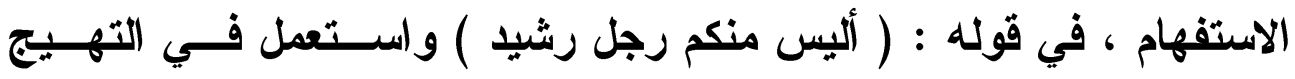

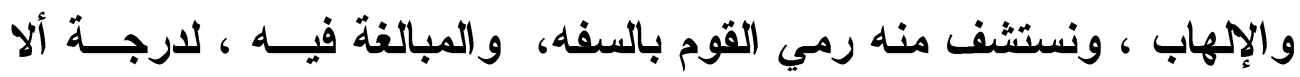

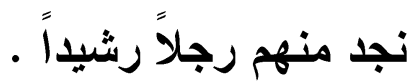

\section{0}




\section{العلدول في سورة هود} دراسة أسلوبية

الاستعارة في اللغة مشتق من الفعل( عور ) ، يقال " اســتعار ثُبــاً

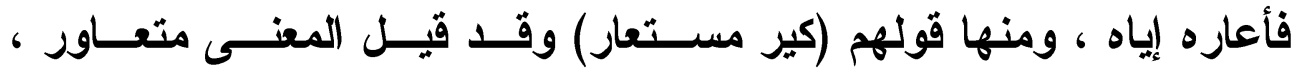
أو متداول . " (911)

والاستعارة في الاصطلاح لها تعريفات عديدة ، ومن تعريفاتها :

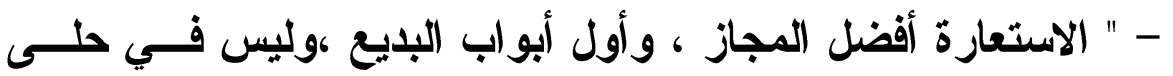

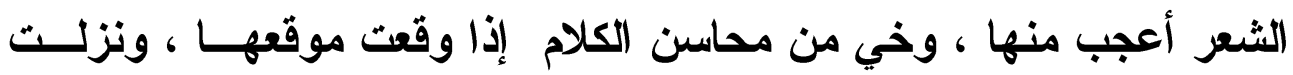

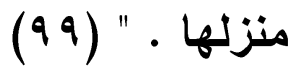

- والاستعارة " نقل العبارة عن موضع استعمالها ، في أصل اللفة ،

$$
\text { إلى غيره لغرض • " ( - (1 ) }
$$

ويكاد يتفق معظم المتأخرين في تعريف الاستعارة ، ومسن ذلــــ : "

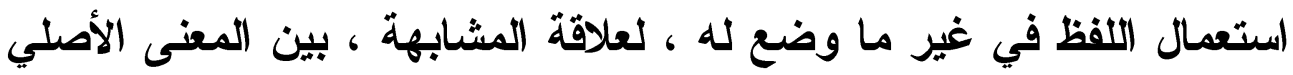

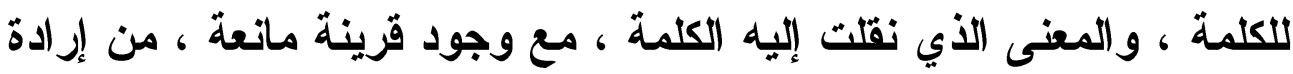

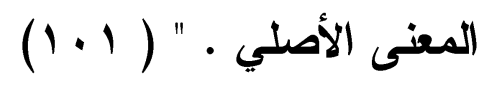
وللاسنعارة مكانة في صناعة الثعر والأدب ؛ فـ " الاستعارة واحدة

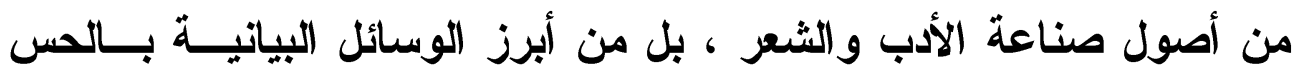

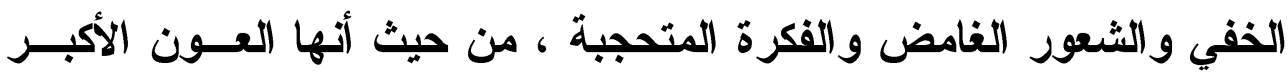
على إبراز كل ذللك، والعبارة عنه ـ " ( r • (1)

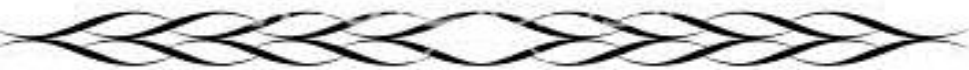




\section{الترقير الدولا \\ ISSN 2356-9050}

ولا يستطيع أحد أن ينكر إعجاز القرآن الكريم ، في تناول الاستعارة،

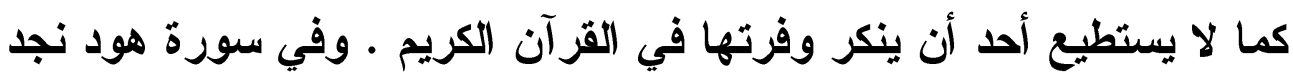

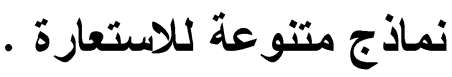

الاستعارة المكنيسة: - قوله تعالى : ( ولئن أذقتا الإسسان منا رحمة

ثم نزعناها منه إنه ليئوس كفور ) ( هود 9

فقي الإذاقة استعارة مكنية ؛ لأنه في الأصل تناول الثئ بالفم ، ثــــ

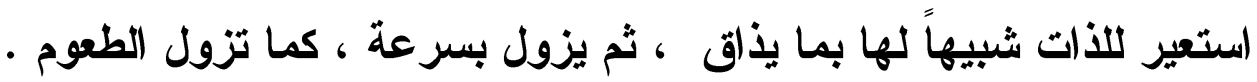
- وقوله تعالى : ( فلما ذهب عن إبراهيم الروع وجاهته البشــى ) $(V \leq 20)$

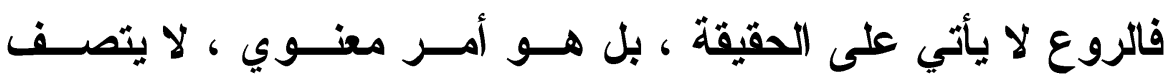

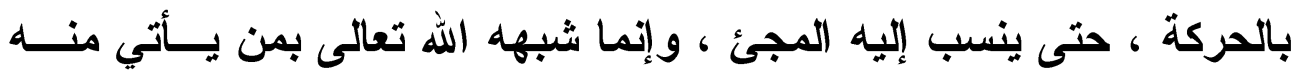
المجئ.

- وقوله تعالى : ( وقيل يالأرض ابلعـي مــاءك وياســماء اقلعـي

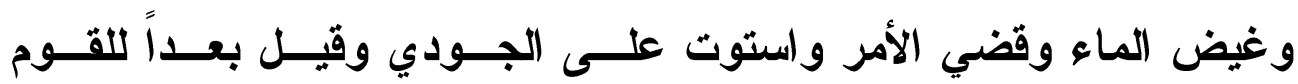

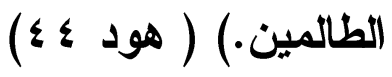

إن الحوار في هذه الآية يدور بين الله عز وجل من من ناحية ، وبين

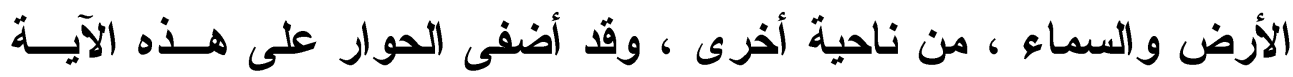

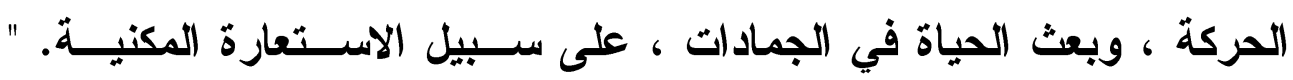

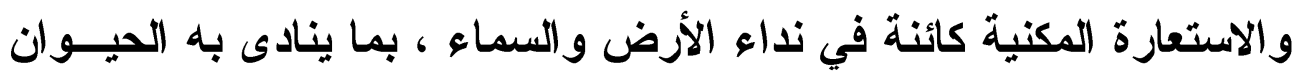
المميز ، على لفظ التخصيص ، والإقبال عليهما بالخطاب ، من بين ســائر

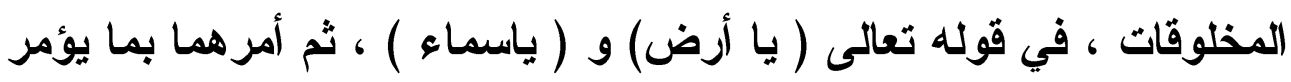




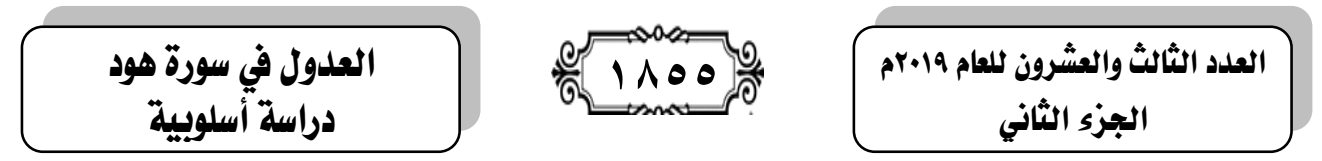

به أهل التمييز والفعل في قوله ( ابلعي ) و ( (قلعي ) ، والبلع عبارة عسن

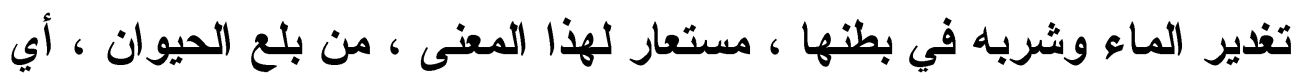
ازدراده لطعامه وشرابه ، والبلع هو أثر القوة الجاذبة في المطعوم ، لكمال

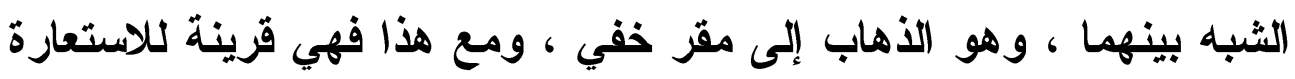

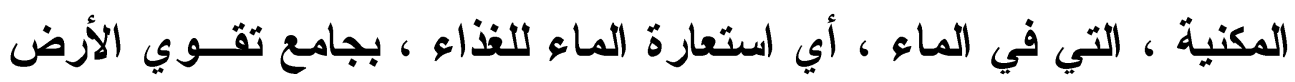
بالماء في الإبات وتقوي الآكل بالطعام • " ( ب • (1)

وهذه الاستعارة فيها تثخيص للجمادات ، ويث الحياة والحركة فيها

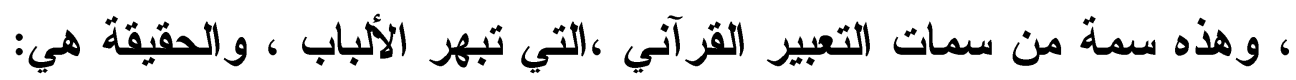

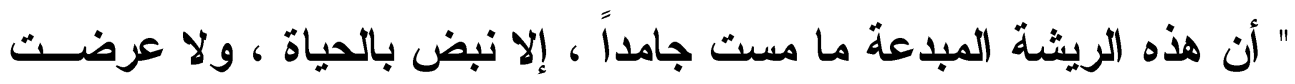

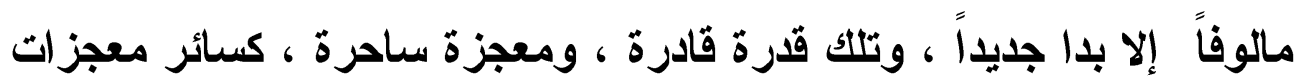

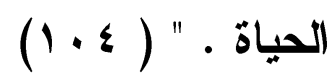

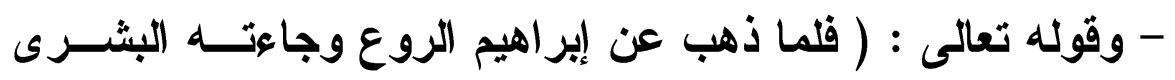

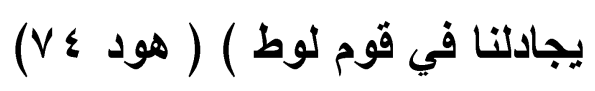

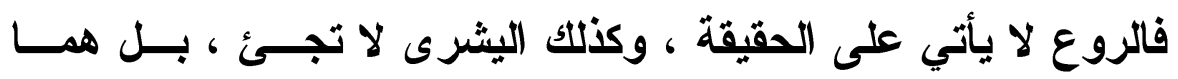

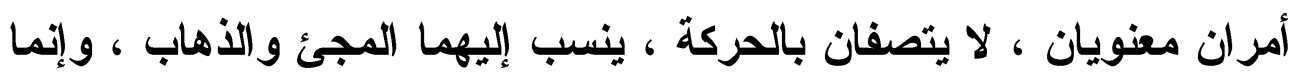

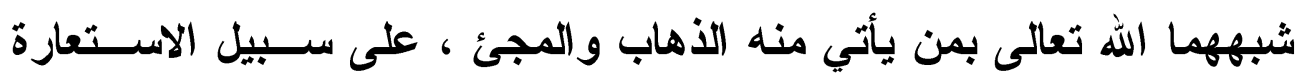
المكنية.

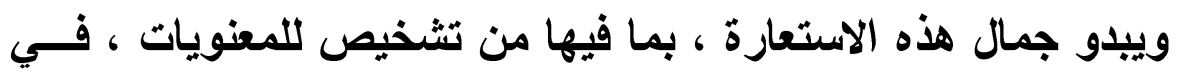

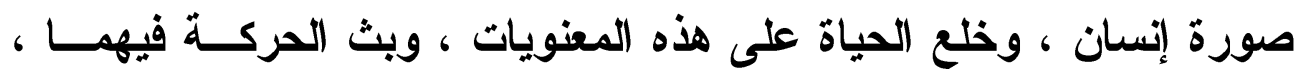

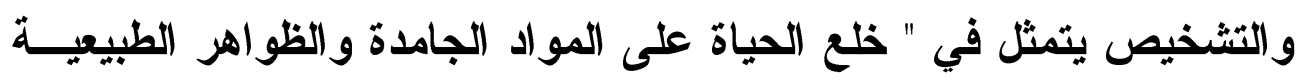

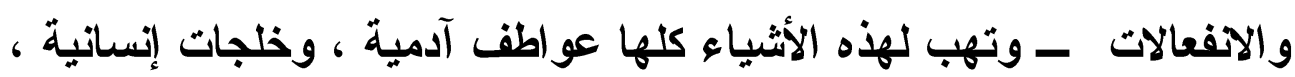

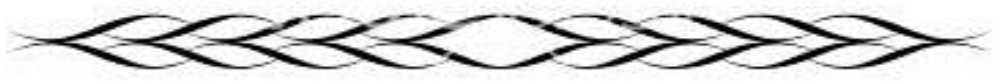




\section{الترقير الدولخ}

ISSN 2356-9050
की 1107

حولية كلية اللفة العربية بجرجا مجلة علمية محكمة

تشارك بها الآدميين ، وتأخذ منهم وتعطي ، وتتبدى لهم في شتى الملابسات ، وتجعهم يحسون الحياة في كل شئ ، تقع عليه العـين ، أو يتلـبس بــــ الحس ، فيأنسون بهذا الوجـود ، أو يرهبونــهـه ، فــي تــوفر (تعجـل ) ، وحساسية ، و إرهاف. " ( 0. 1)

- وقوله تعالى : ( ذلك من أنباء القزى نفصه عليـــك منهــا قـائم

$$
\text { وحصيد ) ( هود +. (1) }
$$

فقد استعار الزرع القائم على سوقه ، لما بقي من آثار القرى ، كما

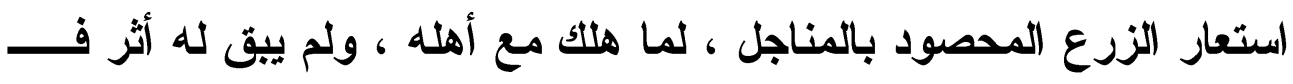
" الآية الكريمة تمثلت فيها استعارة مزدوجة في كلمتي ( قائم ) و ( حصيد)، حيث شبهت الآية الكريمة ما بقي من آثار القزى وجدراتها بــالزرع القـائم

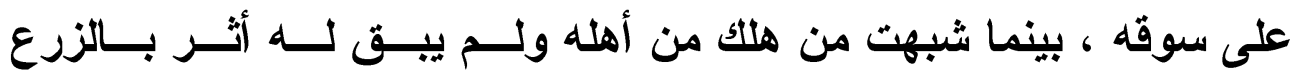
المحصود بالمناجل ، وحذف المشبه به ، وهو الزرع القائم علــى ســوقه ، و الزرع المحصود وأبقى صفة من صفاتهما ، على الترتيب ، وهما ( قائم) و ( حصيد ) ، على طريق الاستعارة المكنية.

الاستهارة التهكمية :

وهي استعمال الألفاظ الدالة على المدح ، في نقائضهما مسن الـــم والإهانة ، فـ " هي استعارة أحد الضدين أو النقيضين للآخـر ، بواســة انتزاع شبه التضاد ، وإلحاقه بشبه التناسب ، بطريق التهكم ، أو التلميح ، ثم ادعاء أحدهما من جنس الآخر ، والإفر اد بالأكر ، ونصــب القرينــة . " 


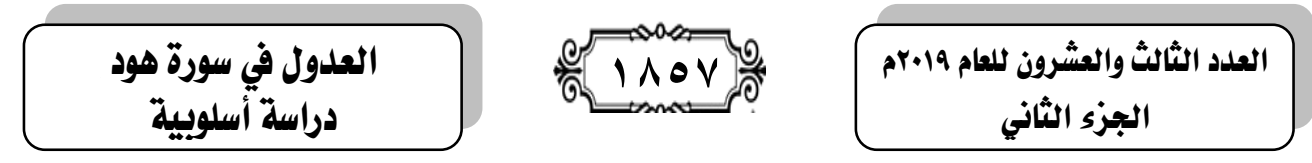

- ومن ذلك قوله تعالى : ( إنك لأتت الحليم الرشيد ) ( هود AV)

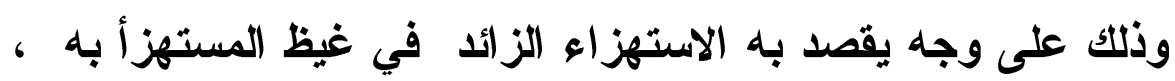

و" عنوا بذلك نسبته إلى السفه والغي على طريق التهكم ـ " ( V ( )

$$
\text { - وقوله تعالى : ( بئس الرفد المرفود ) ( هود 99) }
$$

و " المرفود الموهوب المعان ، فكأنه جعل اللعنة عطاء وإعانة لهم .

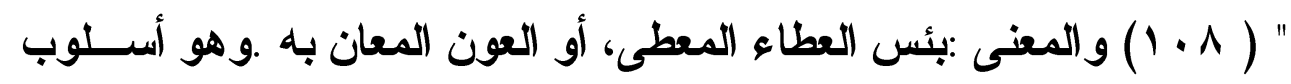

ذمِّوتقبيح.

الاستعارة التمثيلية :

وتعني " اللفظ المركب المستعمل فيما شبه بمعنـــاه الأصــلي تثــبيه

التمثيل للمبالغة في التثبيه، أي :تثبيه إحدى صورتين منتزعتين من أمرين أو أمور بالأخرى، تم تلخل المشبهة في جنس المشبه بها مبالغة في التشبيه

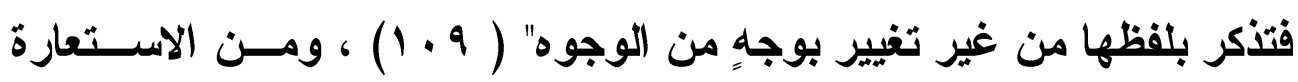

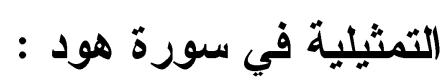

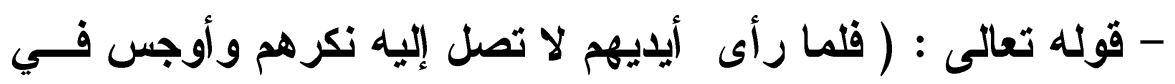

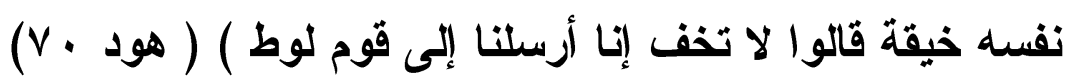

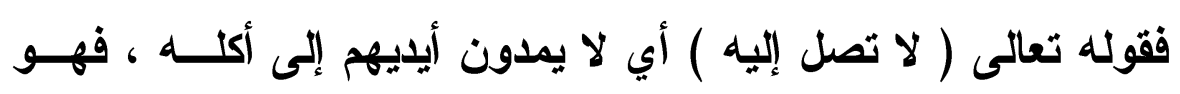
يريد أن ينفي الوصول ، الناثئ عن المد.

- وقوله تعالى:( إني توكلت على الله ربي وربكم ما من دابة إلا هو

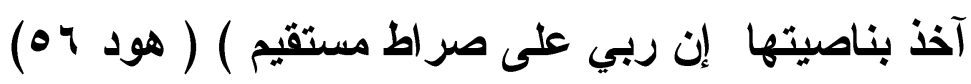

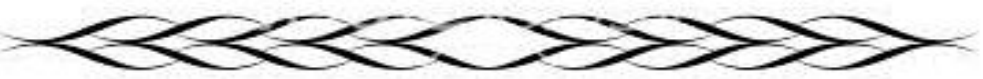




\section{الترقيم الدولي}

ISSN 2356-9050
की 1101
حولية كلية اللفة العربية بجرجا مجلة علمية محكمة

فالصورة شبهت الخلق وهم في قبضة الله وملكــه ، وتحــث قهــره وسلطانه، بالمالك الأي يقود المقدور عليه بناصيته ، كمــا يقــاد الأســير

والقرس بناصيته. ( . (11)

\section{الاستمارة التبـمية :}

وهي " ما تقع في غير أسماء الأجناس كالأفعال والصفات المشــتقة منها ، وكالحروف . " (111) ، ولا تكون هذه إلا مصرحاًه، ، و إنمــــــــيت تبعية؛ لأن المذكور ات لا تقع موصوفات، فتقع في مصادر الأفعال والصــفات، وفي متعلقات معاني الحروف ثم تسري منها إليها.(112)

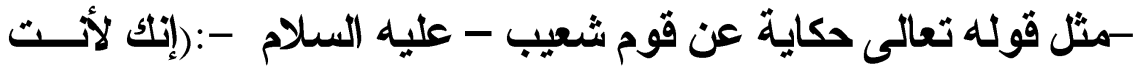
(الحليم الرشياد)( هود V^)

استعار الحلم والرشد للسفه والغواية ثم سرى إلى الحليم الرشيد ، فقد جرث الاستعارة في المصدر أولاً ، ثم انتقلت إلى الصفة المشــبهة ( حلـيم • رشيد )

- وقوله تعالى : ( وأن استغفروا ربكم ثم توبوا إليه يمتعكم متاعـاً حسناً إلى أجل مسمى ويؤتِ كل ذي فضل فضله و إن تولوا فإني أخاف عليكم عذاب يومٍ كبيز ) ( هود ع) ففي قوله ( تولوا ) استعارة تبعية ؛ لأن التولي هو الرجــوع إلــى الخلف ، وهذا ليس المقصود ، وإنما المقصود الإعراض عن الإين ، ونلمح في هذه الاستعارة مدى شدة نفورهم من الدين، فهم لم يعرضوا عنه فقط ، بل تخطوا مرحلة الإعر اض . 


\section{العدول في سورة هود دراسة أسلوبية}

- وقوله تعالى : ( ولئن أذقتاه نعماء بعد ضرَّاء مسته ليقولن ذهب

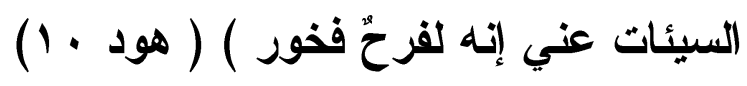

في الآية استعارتان ، في الأولى شبه الإحساس بالنعمة ، بما يــــاق

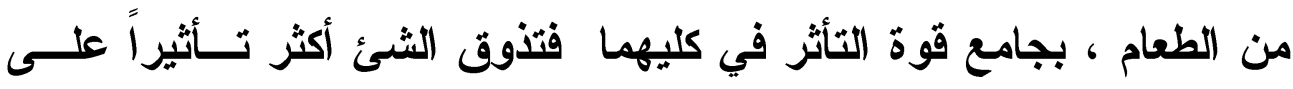
الإسسان ، من الإحساس به ، و التعبير بلفظ أذقتاه يجسد النعمة فــي شـــل

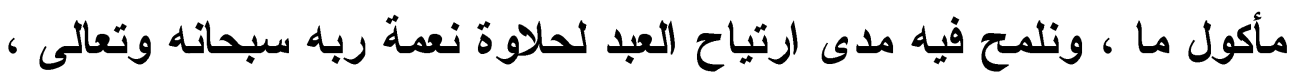

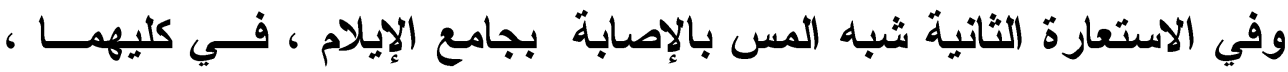
فاستخدام لفظ المس يوحي بإلحاق الضر ، بجميع جسم الإسان وبشاعته.

\section{ثالثـاً}

\section{| الكناية}

الكناية " لفظ أطلق وأريد لازم معناه الحقيقي ، مع قرينة لا تمنع من

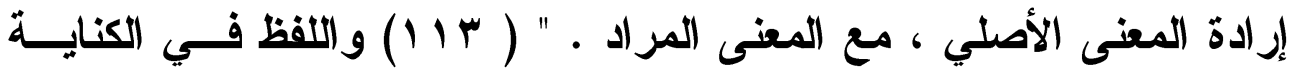

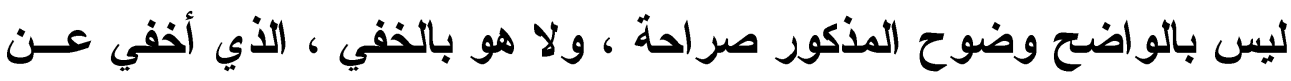

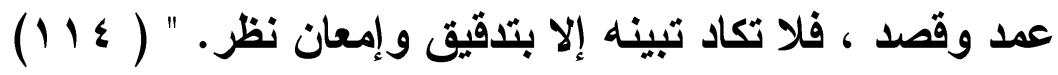
ولاثك أن في الكناية عدولاً ؛ حيث " معنى العدول من لفظ إلى آخر

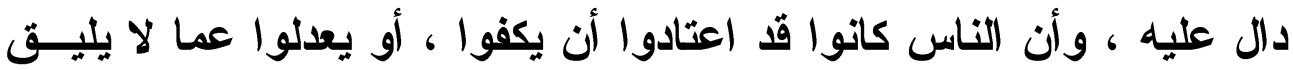

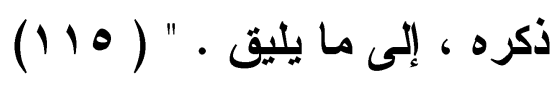

وقد تذكر الكناية ، ويكون المقصود بها الغرض الأصـلـي ، ولــيس

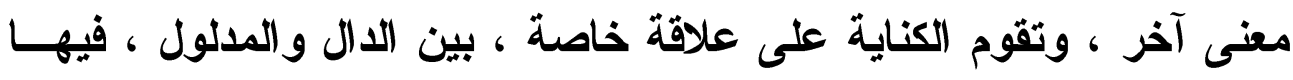

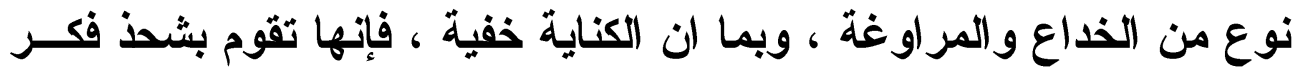

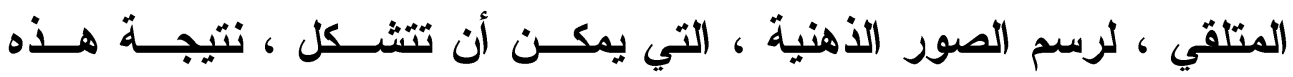

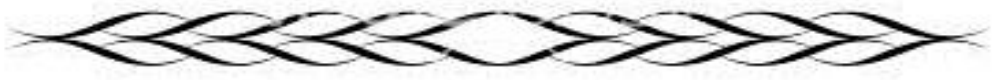




\section{الترقير الدولخ}

ISSN 2356-9050
की. 1197.

حولية كلية اللفة العربية بجرجا مجلة علمية محكمة

المراوغة ، أو العدول عن التعبير المباشر ولذا يكون القبول مرهوناً فـي

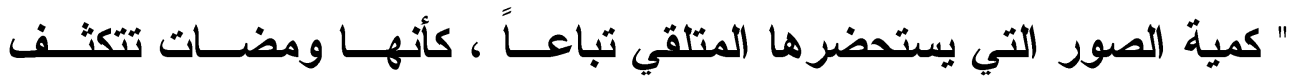

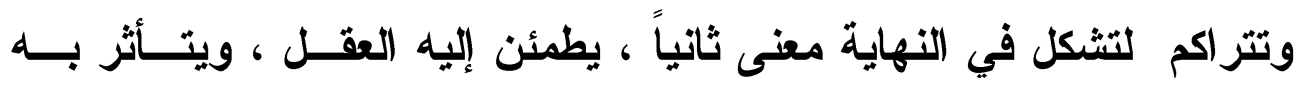

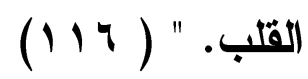

فالهدف من وراء الكناية ، والعدول بها عن التعبير المباشر ، عمـــا يجول في الخاطر ، هو التأثير في نفس المتلقي ، وجعله يمعن في التفكير ،

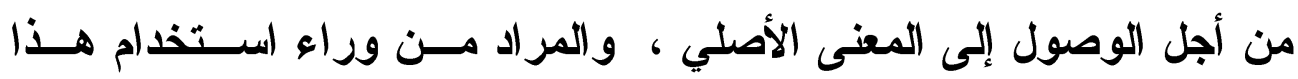

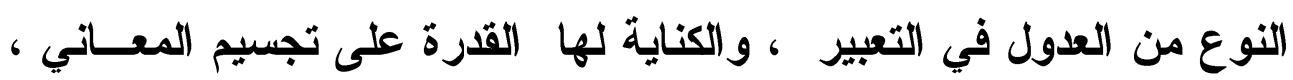
ووضعها في صورة حسية ، تروق وتعجب القارئ وتبهره ؛ لأنه يرى ما كان يعجز عن رؤيته ، فيتضح له ما خفــي عiــهـ بجــلاء ، ومــن أبـرز خصائصها التعبير عن اللفظ القبيح المستهجن ، بالجميل المألوف .

والكناية تنم عن المبالغة في الوصف ، فهي أبلغ مـن التصـريح ؛

لأنها تذكر الثئ بواسطة لازمة ، ووجود التلازم يدل على وجود الملـزوم ،

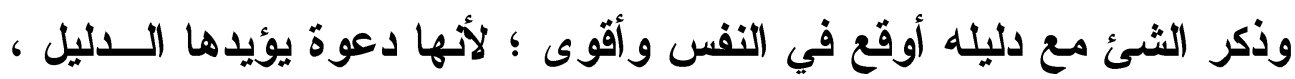
وهذا الفن من صور البيان يبرز المعقولات في الصور المحسوسة ، ويــذلكك يكثف عن أداء معانيها خير أداء ، فتتمكن في نفـس الســامع ، فيـزداد

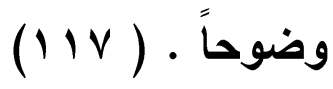

\section{0}


العدول في سورة هود

دراسة أسلوبية

\section{وهن نهاذج الكناية في سورة هود:}

- قوله تعالى : ( وما نرالك اتبعك إلا الذين هم أراذلنا باديَ الرأي )

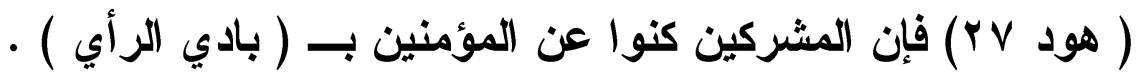

- وقوله تعالى : ( .. إني أخاف عليكم عذاب يوم محيط ) ( هود ع ^)

$$
\text { كناية عن الهلاك. }
$$

- وقوله تعالى : ( قالو القد علمت ما لنا في بناتلك من حـق و إنــــ لتعلم ما نريد ) ( هود V9 كناية عن إنيان الأكور.

- وقوله تعالى : ( قال يانوح إنه ليس من أهلك إنه عمل غير صالح

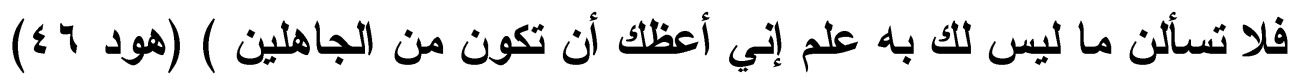
فقد كنى عن بالجهل عن الأنب ، وتلمس في هذا الأسلوب الحث على معرفة الباعث على الأنب ، والتوصل إليه والتنفير منه وتجنبه ، لما فيه من لن النه

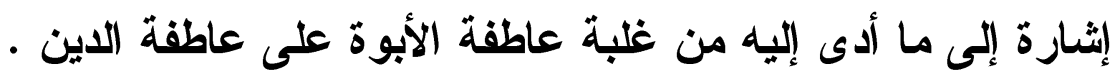
- وقوله تعالى : ( أم يقولون افتراه قل فأتوا بعشر سور مفتريــات و ادعوا من استطعتم من دون الله إن كنتم صادقين ) ( هود ب ا )

حيث كنى بقوله ( من استطعتم ) عن جميع المخلوقات ، وفي هـــا إثبات لعجزهم وضعفهم ، وتعجيز لهم في الإتيان بمثل هذا القرآن ، وتأكيــ نزول القرآن من عند الله في أذهانهم ، لذلك كان الوصف وهيز ( مسن دون الله ) وهو كناية عن موصوف .

- وقوله تعالى : ( أولئك الذين خسروا أنفسهم وضل عنهم ما كانوا

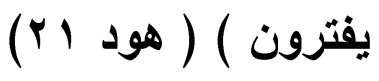

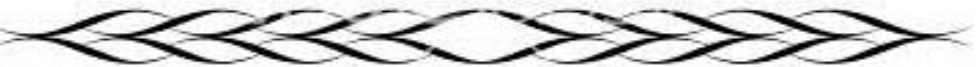




\section{الترقير الدولخ}

ISSN 2356-9050
क. 1194
حولية كلية اللفة العربية بجرجا مجلة علمية محكمة المية

فقوله تعالى ( خسروا أنفسهم ) كناية عن تجردهم من كل فضـل ،

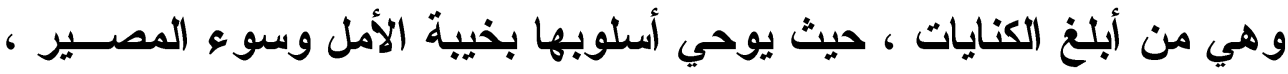
لأن الخسارة وجهت للنفس ذاتها ، ومن خسر نفسه فخسران ما عداها يعد

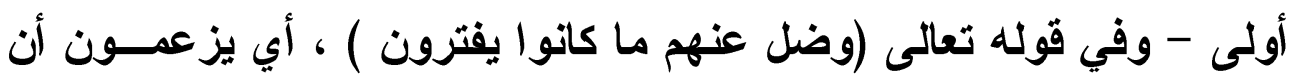

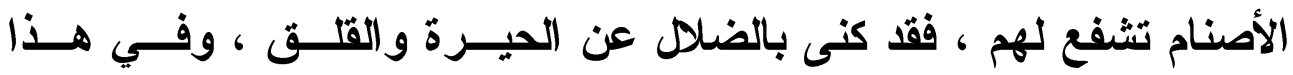

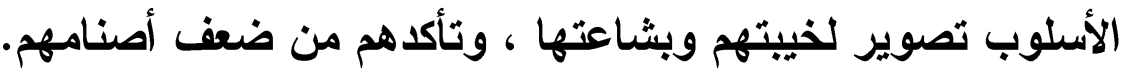

التهريض:

و التعريض هو " اللفظ الدال عـن الثـــئ عـن طريــق المفهـوم .

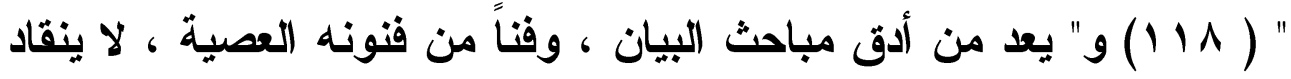
ولا يسهل لكل من رامه ، أو حام حول حماه ، وفقد دلالته ، لا يناله إلا من

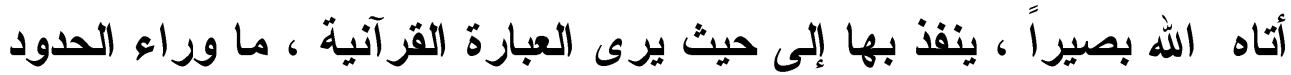
التي تنتهي إليها بلاغات البشر ." ( 119 " وقد دقت مباحث هذا الفن ، وندر الحديث عن مسائله ، لعدم وجود

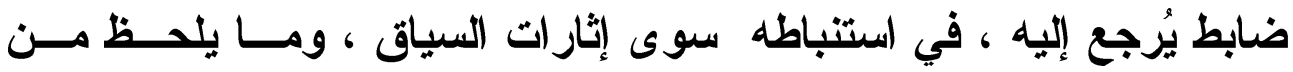

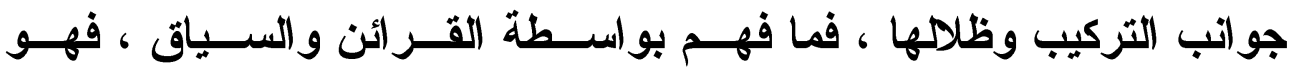

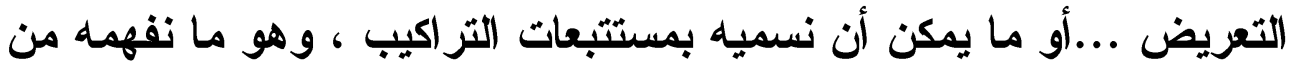

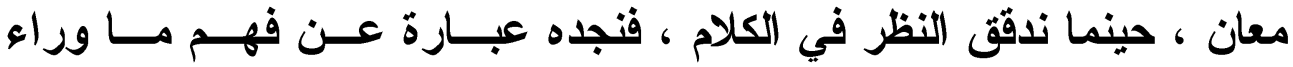

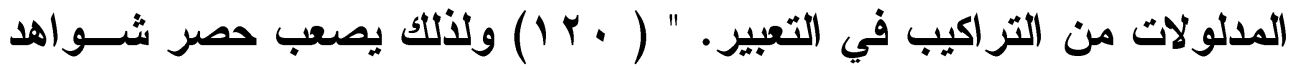
التعريض ؛ لأنه يتوقف على ملاحظة واستشعار ظلال التر اكيب ، و الملاحظة و الاستشعار متفاوتتان من شخص لأخر، بقدر دقة التأمل وحسن الملاحظة . 

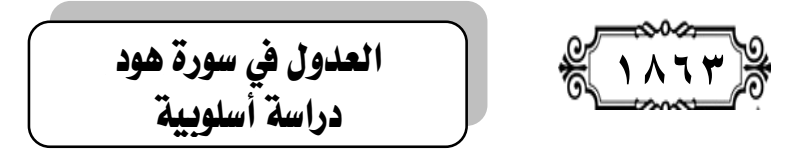

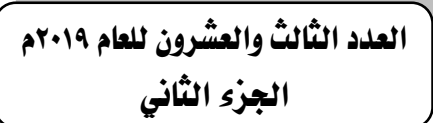

\section{وهن نماذج التعريض في سورة هود:}

- قوله نعالى : (ققال الملأ الذين كفروا من قومه ما نرالك إلا بثــرا

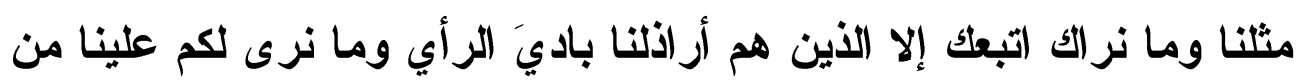

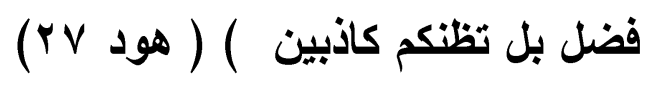

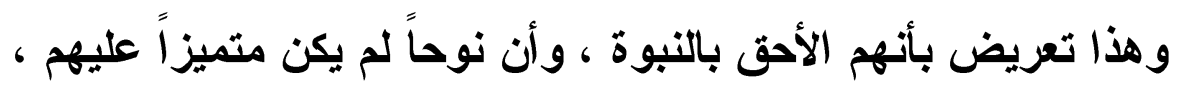

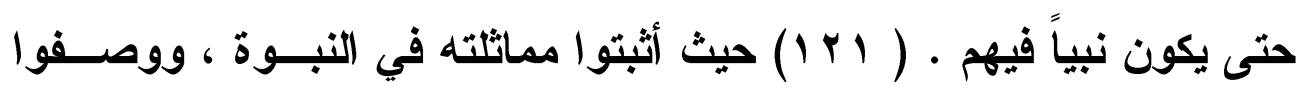

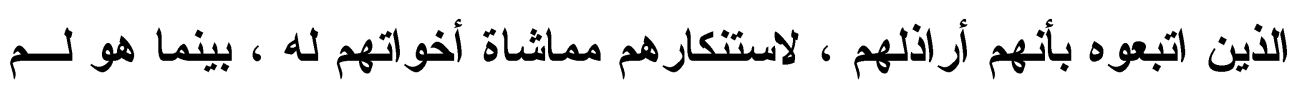

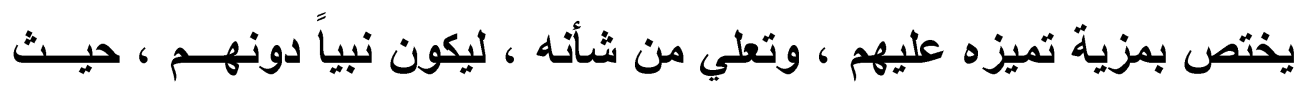

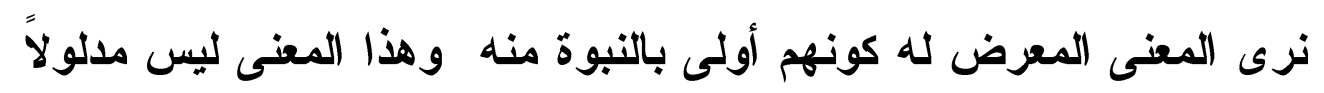

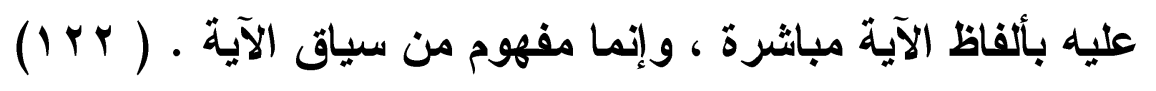
- وقوله تعالى : ( وقيل يا أرض ابلعـي مــاعك وياســماء اقلعـي وغيض الماء وقضي الأمر واستوت على الجودي وقيل بعداً للقوم الظالمين) ( هود $)$

(وقيل بعداً للقوم الظالمين ) تتبيه لســالكي مســلكهم ، والجـاتحين

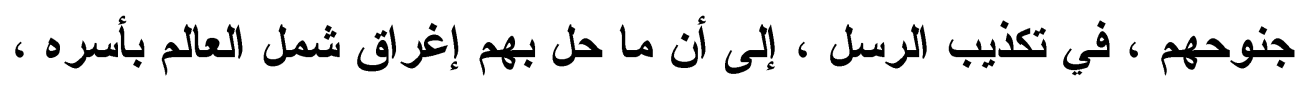
لم يكن إلا لظلمهم ، و إمعانهم في اللجاج ، و التمادي في الإنكار.

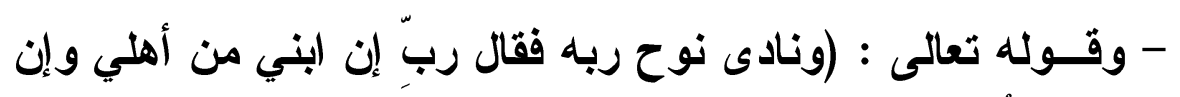

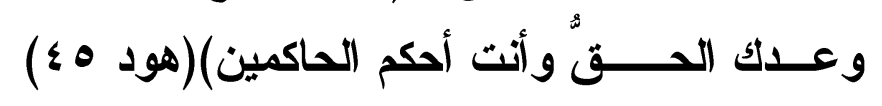
هذا تعريض من نوح - عليه السلام - بسؤال عن حكمة الله ، التي

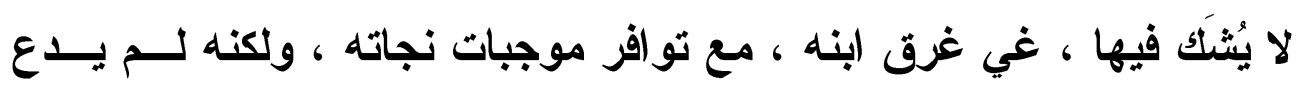

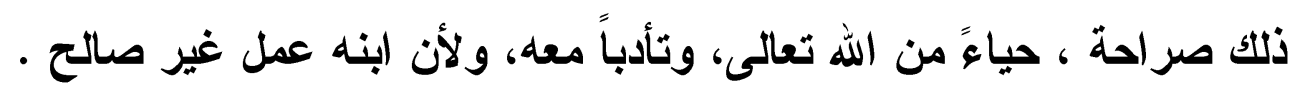

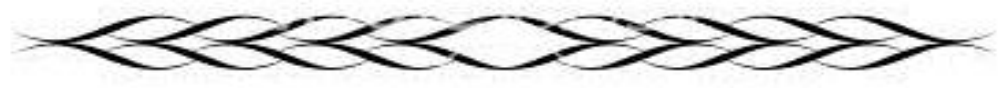




\section{الترقيم الدولخ}

ISSN 2356-9050
0. $114 \varepsilon$
حولية كلية اللفة العربية بجرجا

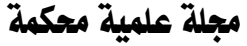

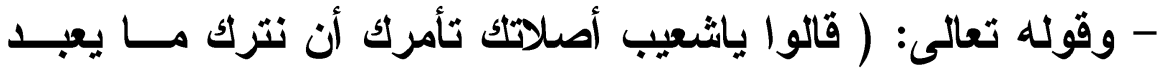

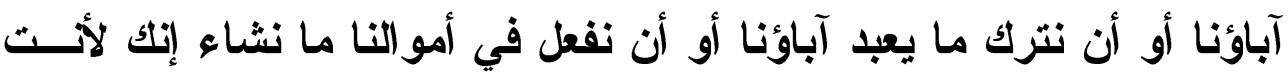

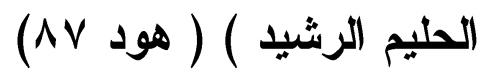

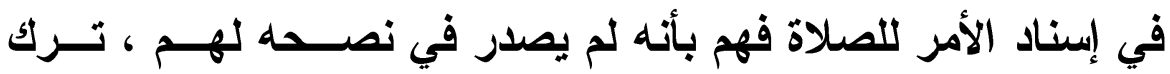

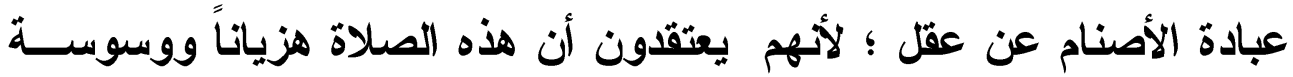
شيطان ، فقي قولهم هذا تهكم به ، وتعريض بذهاب عقله .

- وقوله تعالى : ( فلما جاء أمرنا نجينا صالحاً والذين آمنوا معسه برحمةٍ منا ومن خزي يومئذٍ إن ربك هو القوي العزيز وأخذ الـــين ظلمــوا

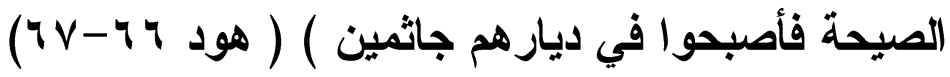

ففي الآيتين جاء التعبير باسم الموصول ( الذين ) عن ثمود ، وفيسـه

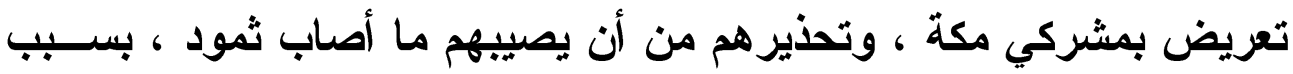

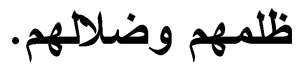

- وقوله تعالى : ( وما ظلمناهم ولكن ظلموا أنفسهم فما أغنت عنهم ألهتهم التي يدعون من دون الله من شئ لمَّا جاء أمر ربك وما زادوهم غير ولهم

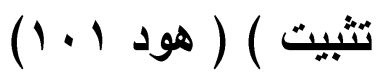

حيث جاء التعبير (أغنت عنهم ألهنهم) ، ليؤدي دوره الاقيق ، فــي تنبيه المشركين وتحذيرهم ، من الاعتماد على نفع الأصنام ، وهم قد عرفوا

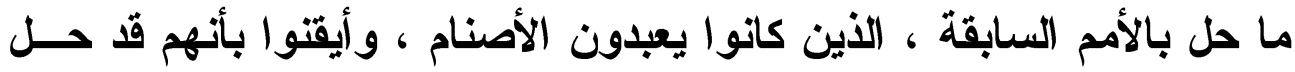

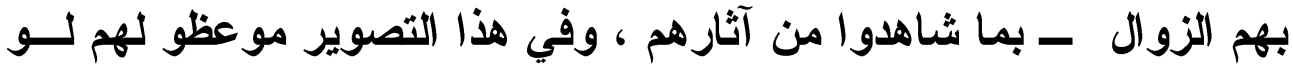

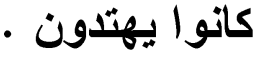




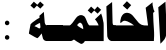

- هناك مستويان للفة ، أحدهما معياري نمطي ، خاضع للضـــوابط و المعايير التي أرسى دعائمها النحاة وهناك المستوى الفني الذي يعـالج

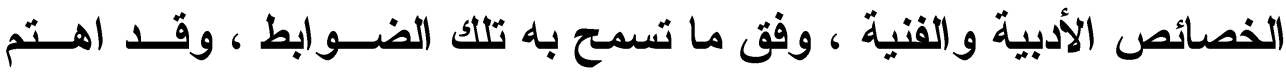
البلاغيون بهذا المستوى ، دون إهمال للمستوى النمطي؛ الأي عدوه معيارً لعدول في الأعمال الأدبية . ل العنون

- والعدول في النص القرأني، ليس خروجاً أو خرقاً لنظام العربية ،

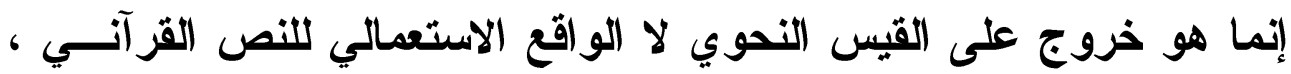
وهو نظام العربية نفسه ، في أعلى درجاته الإبداعية البلاغية لتؤدي اللغــة

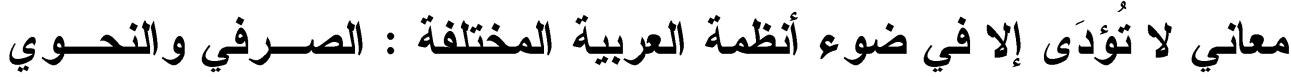

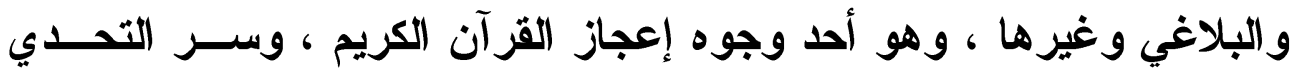

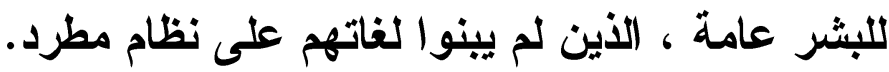
- إن العدولات في سورة هود تستوقف المتلقــي ، وتخرجسه مــن

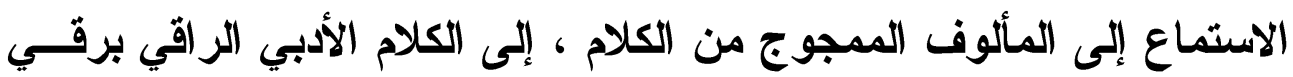
اللغة ، حيث يعد العدول إلى كسر الرتابة فـــي التعبيـر ، لإحــاث الأثـــر المرجو.

- وقا أسهم الالتفات في ( سورة هود ) في الاتثقال من أســلوب

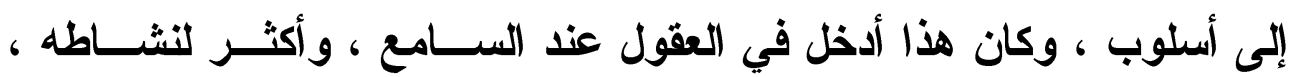

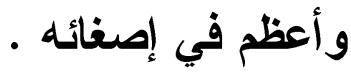

- في الحذف نجد أن العدول الفني في هذا النوع من التركيب ـ يثير

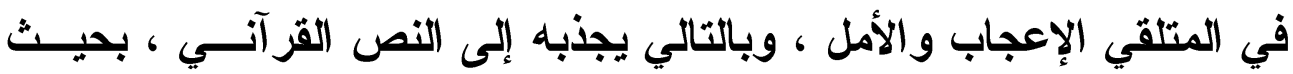

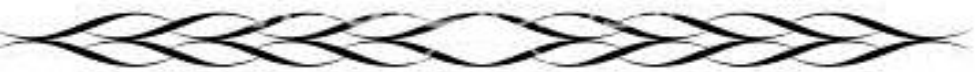




\section{الترقير الدولخ}

ISSN 2356-9050
0. 1197
حولية كلية اللغة العربية بجرجا مجلة علمية محكمة

يكون متلقياً وفاعلاً في الوقت نفسه ، وذلك من خلال إعمال فكـره ، مـنـ

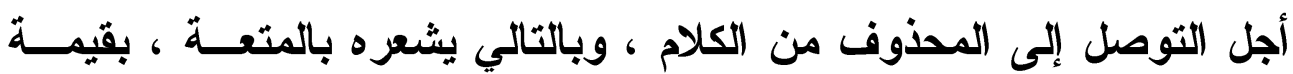

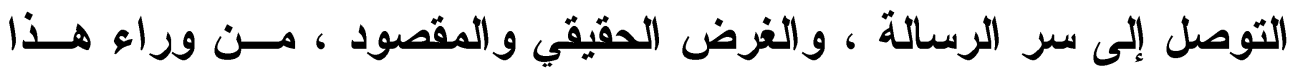

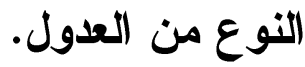

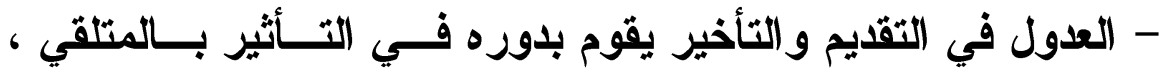
ويحفزه على التأمل والتدبر ، فيما يسمع أو يقر أ من آيات القرآن آلكريم. - لقد عدل النص القرأني باستخدام المجاز لرسم صورة فنية موحية

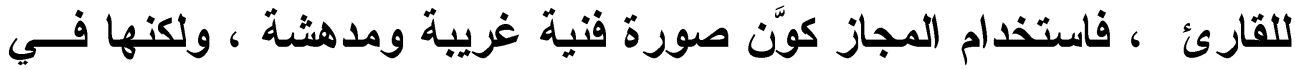
الوقت نفسه ماتعة للمتلقي.

- يمارس المجاز أو العدول أهمية كبيرة في النص ، فهو يمسارس

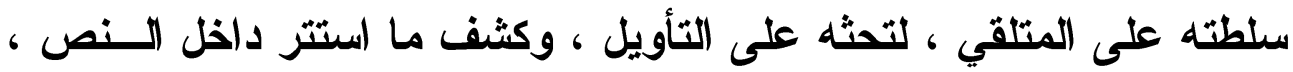

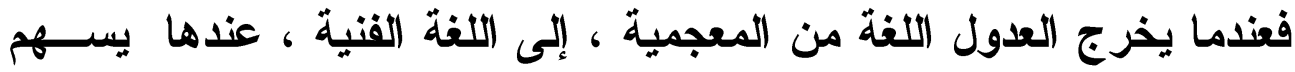
في تحريك مشاعر المتلقي ، وتحفيز حواسه ، وإطــلاق خيالــهـ ، وإثــارة عو اطفه ، ويقف على حقيقة المشاعر والأحاسيس .

- في الأسلوب العدولي المعروف بالكناية ، يعرض القرآن الحقـائق

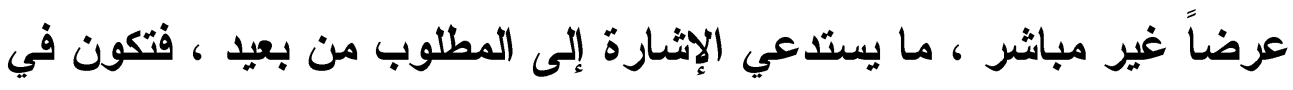

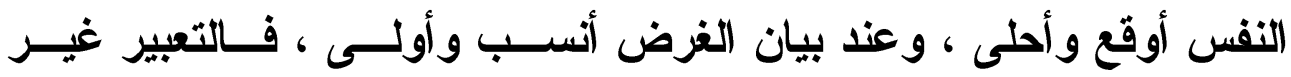

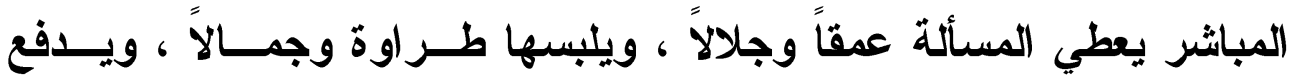

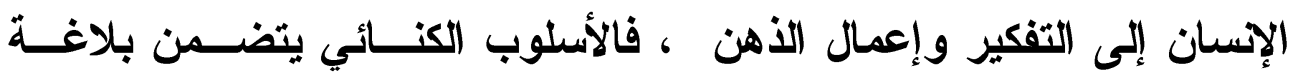

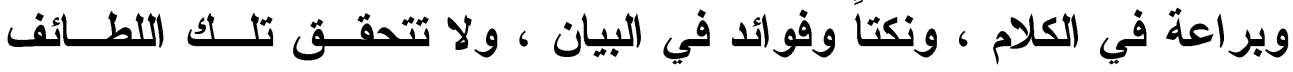

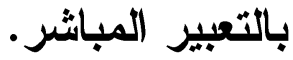




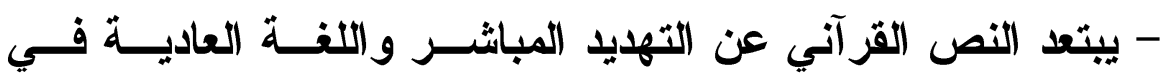

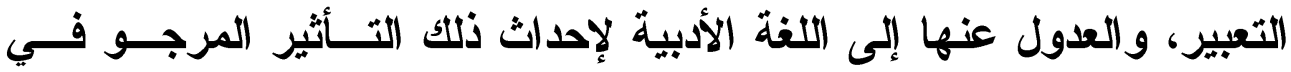
المتلقي ، فالمتلقي عندما تكسر أمامه حواجز اللغة ، بشرط قبولهالها لإهات ، فإنه تثير اعتمامه وتثعره بروعة التعبير والصياغة.

- جاءت الكنايات القز آنية في سورة هود قمة في الأداء، وروعــة

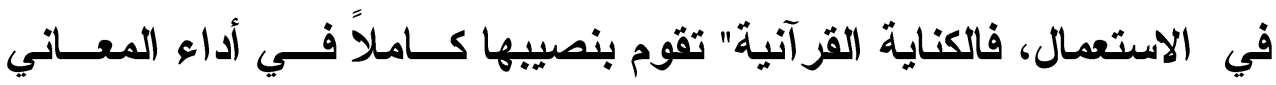
وتصوير ها خير أداو، وأد ق تصوير، وهي حيناً راسمة مصورة موحية، وحيناً مؤد بَّبة

مهذبَّة، تتجنب ما تنفر الأذن من سماعه، وحيناً موجزة تنقل المعنـى

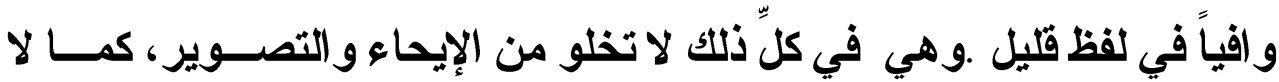
تستطيع حينئذٍ أن تؤدي المعنى كما أكتده الكناية مشعاً موحياً، ومصوراً معبراً - كما اتازت التعريضات القرآنية في سورة هود عليـهـ السـلام؛

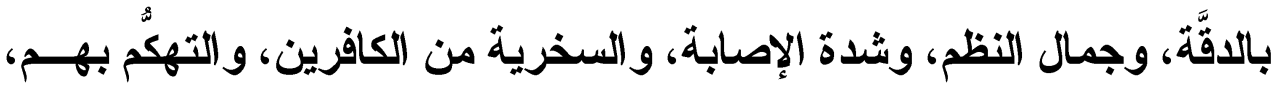
ورميهم بالغباوة و الجهالة، وفساد العقل، وسو ء المصير . 


\section{الترقيم الدولخ}

ISSN 2356-9050

\section{الهماهوش:}

(1) ينظر. الفيروز أبادي ، القاموس المحيط ، تحقيق. أنس محمد الشامي وزكريا جابر أحمد ، مادة عدل ، القاهرة ، دار الحديث، 1 . . بم م

(Y) ينظر • ابن منظور ، لسان العرب ،مج ، 1 ، مادة عدل ، طج، بيروت

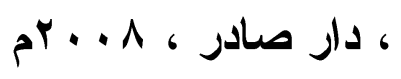

(r) الأزهري ، تهذيب اللغة ، تحقيق محمد عوض مر عب ، مادة عـدل ،

$$
\begin{aligned}
& \text { بيزوت ، دار إحياء التراث العربي ، 1 +. بام } \\
& \text { (ع) القيروز أبادي ، القاموس المحيط ،مادة عدل . }
\end{aligned}
$$

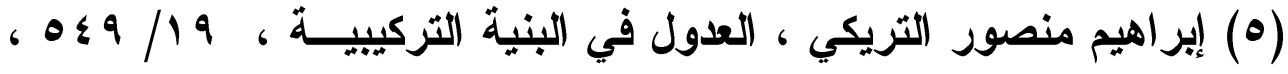
ع · r ، مجلة جامعة أم القرى لعلوم الثريعة واللغة العربية و آد (بها ،

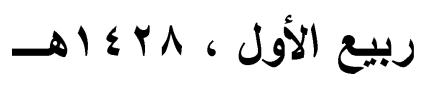

(7) عبد الله عبد الرحمن با نقيب ، العدول والأداء الشعري ، جذور ، جع /

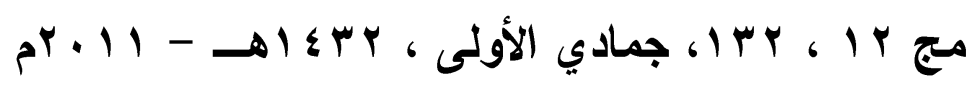

عبد الموجود مثولي بهنسي ، رؤية العدول عن النمطية فــي التعبيـر الأدبي ، ه، الرياض ، مكتبة الرشد للنشر والتوزيع ، ب9 9 ام

(^) عبد السلام المسدي ، الأسلوبية والأسلوب ، وس اه طس، الدار العربية

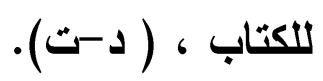

(9) عبد الحميد أحمد يوسف هنداوي .الإعجاز الصرفي في القرآن الكـــيم :

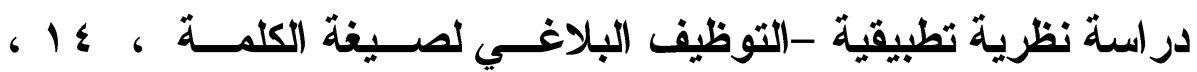

$$
\text { المكتبة العصرية ، صيدا ، بيروت ، ب . . ب م. }
$$




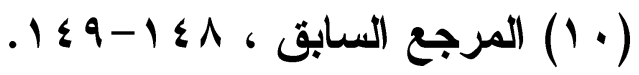

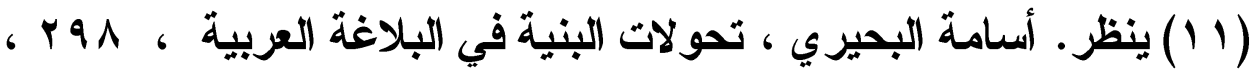
دار الحضارة للطبع والنشر والتوزيع ،القاهرة ، . . . Y م.

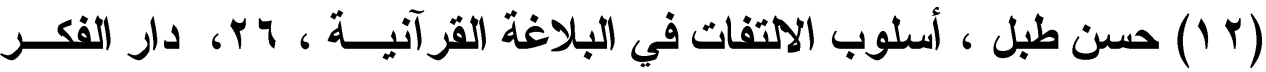

$$
\text { العربي ، القاهرة ، } 9191
$$

(T I I ) عبد الحميد أحمد يوسف هنداوي ، الإعجاز الصرفي في القرآن الكريم

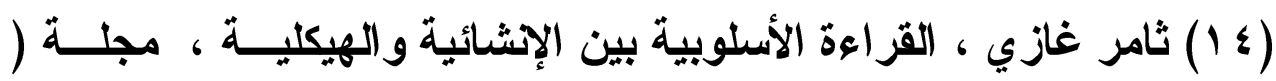

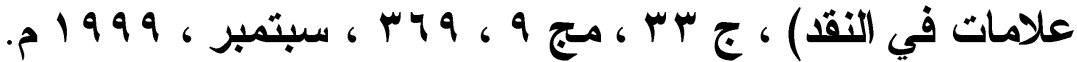

(0 1 ) أبو بكر بن السراج ، الأصول في النحو ، تحقيق د. عبـــ المحسـن

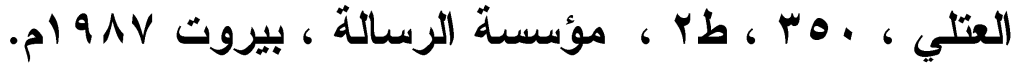

(7 1 ) ينظر • (بن رشيق ، العمدة ، تحقيق محمد محي الاين عبد الحميـــ ،

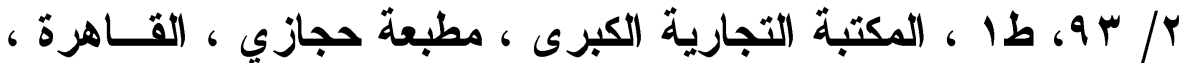

$$
\text { p) } 9+\varepsilon
$$

. IV / / ا ينظر • المصدر السابق ( V)

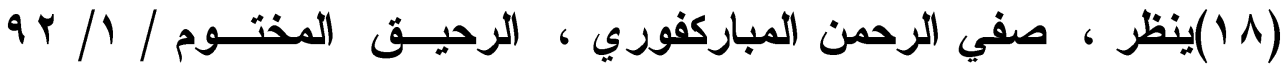

$$
\text { p) } 99 \leq 6(b-د) \text { 6 }
$$

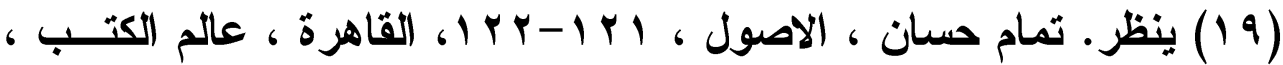

$$
\text { r... }
$$

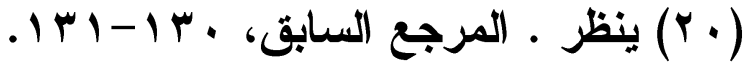




\section{الترقيم الدوله \\ ISSN 2356-9050}

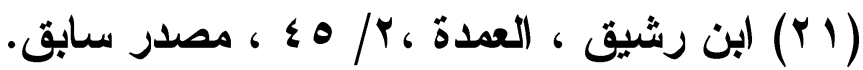

(Y r الخطيب القزويني ، الإيضاح في علوم البلاغة ، V ا I ، دار الكتاب

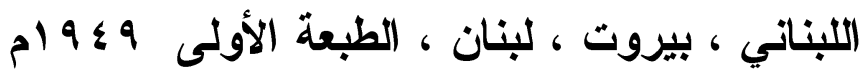

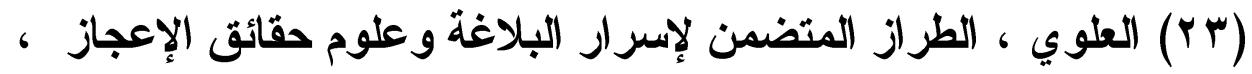

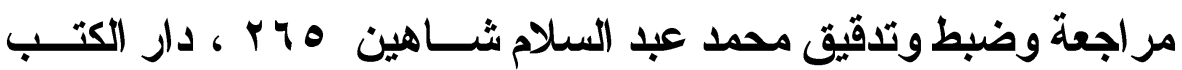

$$
\text { العلمية، بيروث لبنان، الطبعة الأولى ه9 } 99 \text { م. م. }
$$

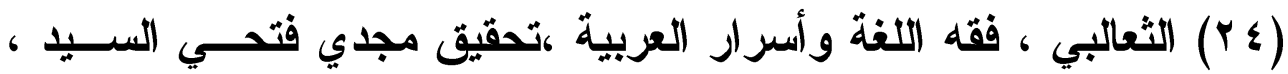

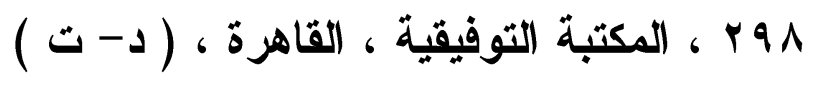

(ro ) ينظر • محمد صلاح زكي أبو حميد ، الخطاب الشعري عنـــ محمــود

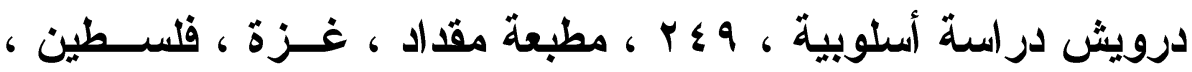

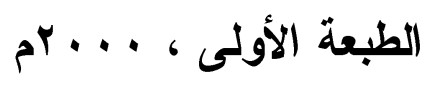

(Y Y ) عبد الرحمن حسن حبنكة الميداني ، البلاغة العربية أسسها وعلومهــا

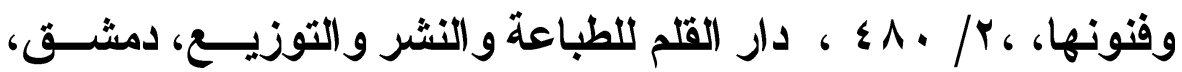

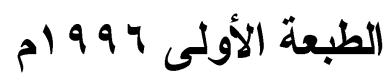

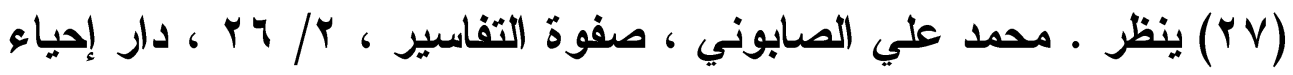
التراث العربي للطباعة والنشر والتوزيع ، بيروت - لبنـان، الطبعـة

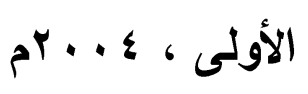

( الزركثي ، البرهان في علوم القرآن ، تقديم وتعليق مصـــى عبـــ

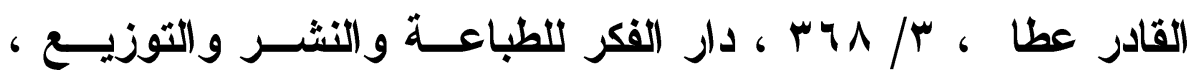

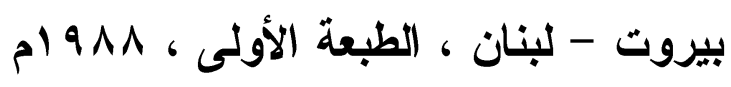




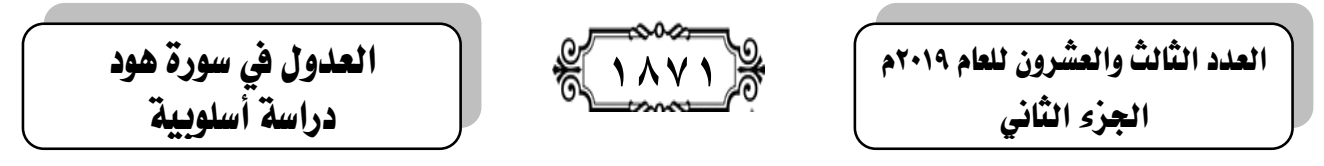

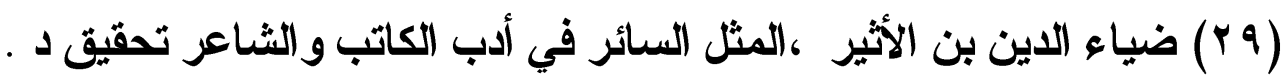

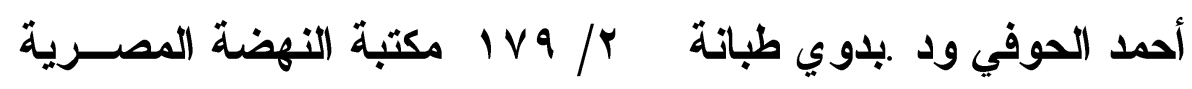

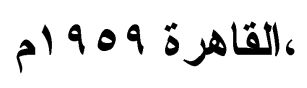

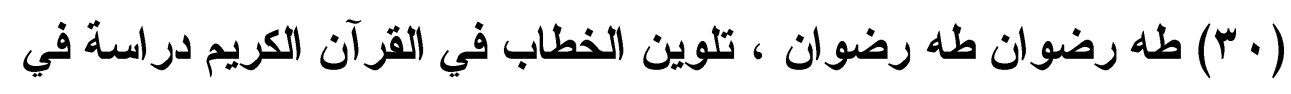

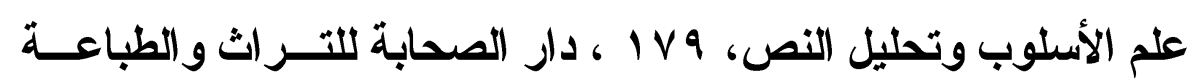

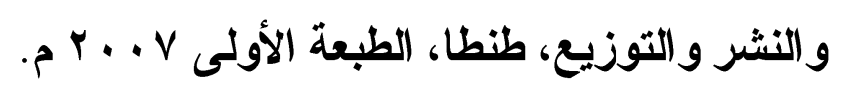

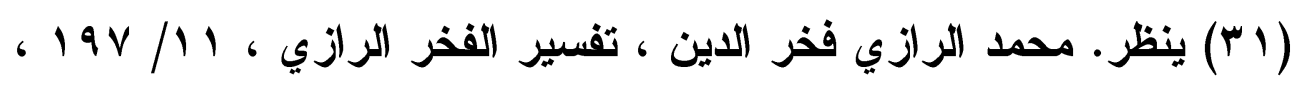

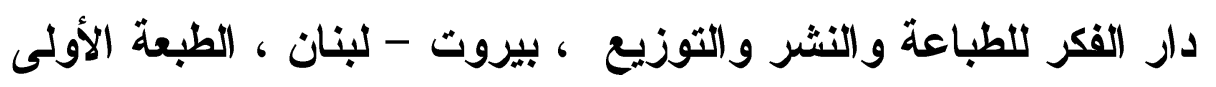

$$
\text { م)911 }
$$

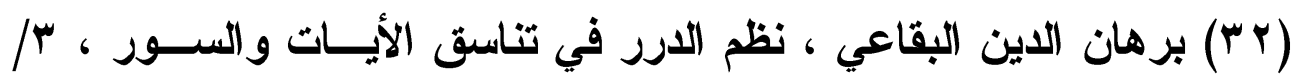

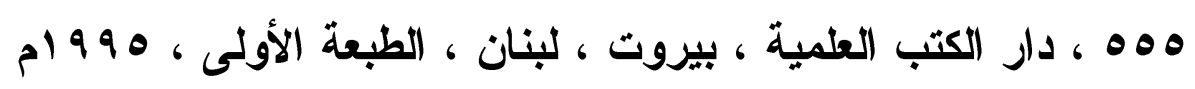

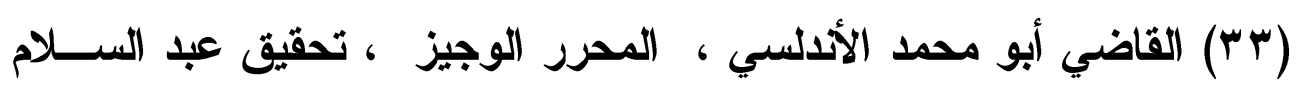

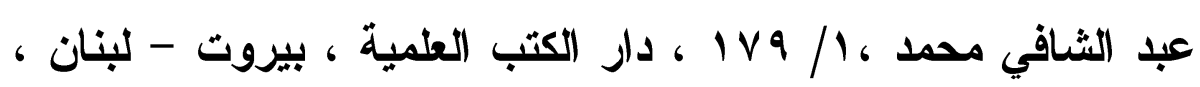

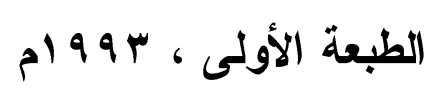

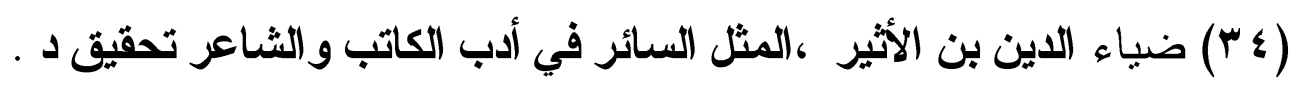

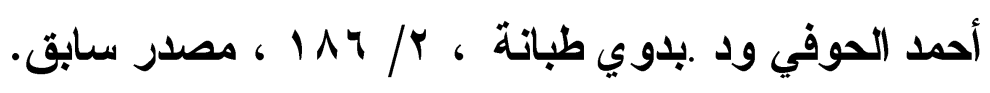

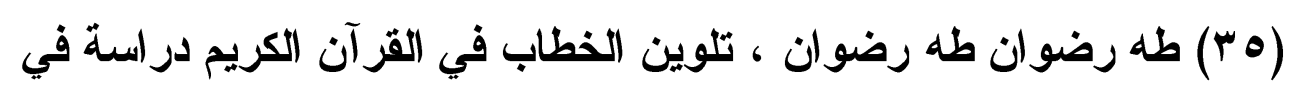

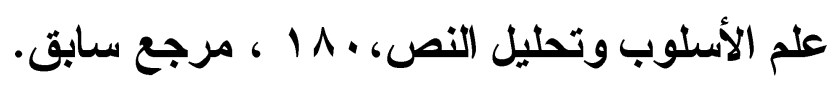




\section{الترقير الدولخ}

ISSN 2356-9050 OPN $11 \mathrm{~V}$
حولية كلية اللفة العربية بجرجا مجلة علمية محكمة

( آبا) العلوي ، الطراز المتضمن لإسرار البلاغة وعلوم حقائق الإعجاز

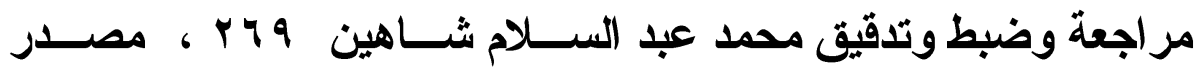
سابق.

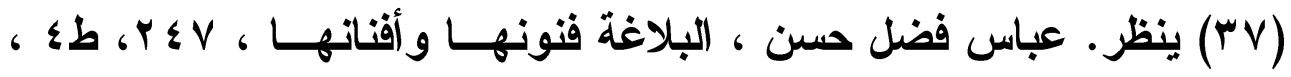

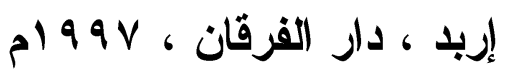

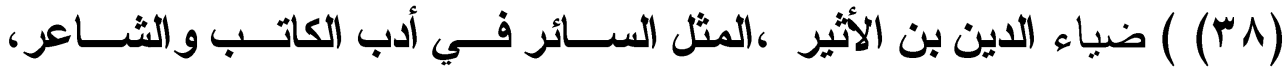

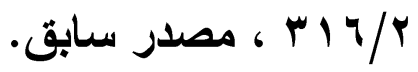

(جq) ينظر. إبراهيم منصور الترمكي ، العدول في البنية التركيبية ، قــراءة

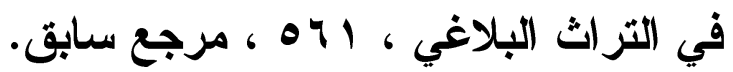

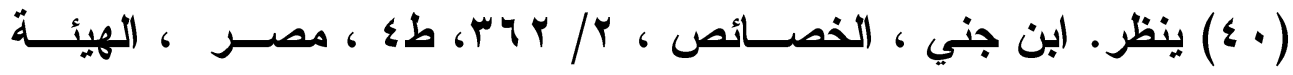

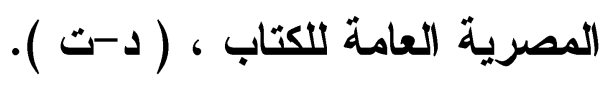

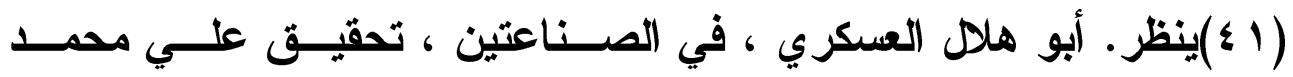

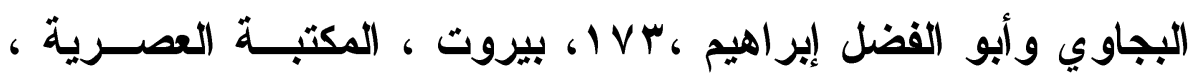
$-1 \leqslant 19$

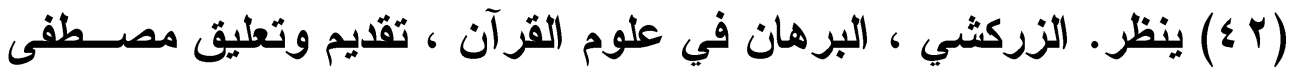

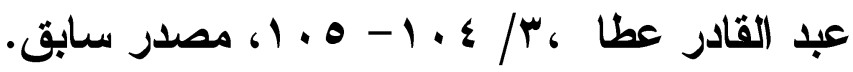

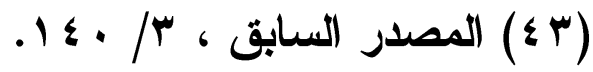

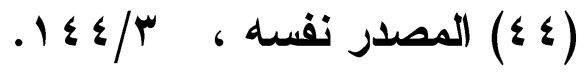

(0 ؛ ) مختار عطية الإيجاز في كلام العرب ونص الإعجاز دراســة بلاغيـة،

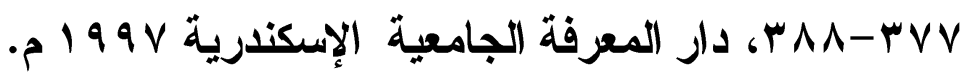


العدول في سورة هود

دراسة أسلوبية
العدد الثالث والعشروز للعام 19 العزئ

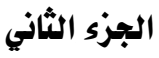

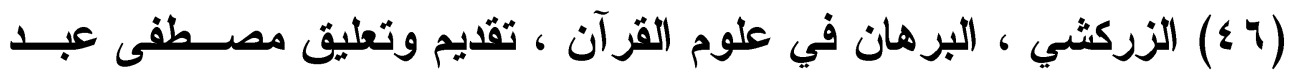

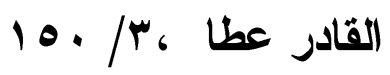

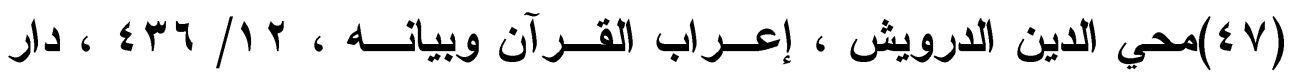

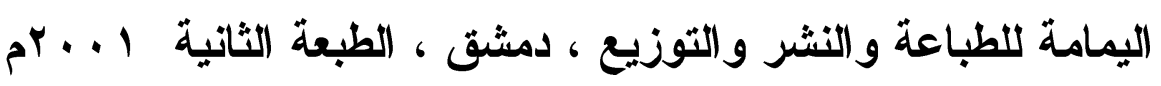

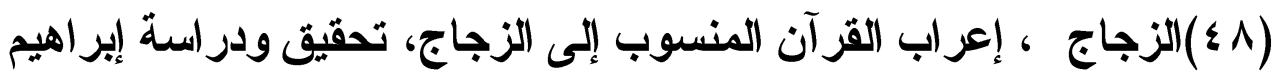

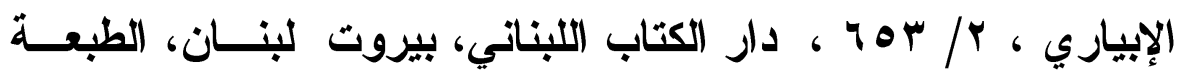

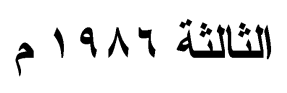

(9 ؛ ) العلوي ، الطر از المتضمن لإسرار البلاغة وعلــوم حقــائق الإعجــاز

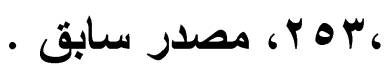

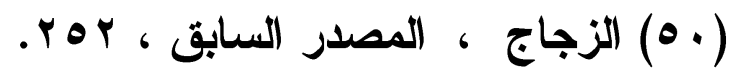

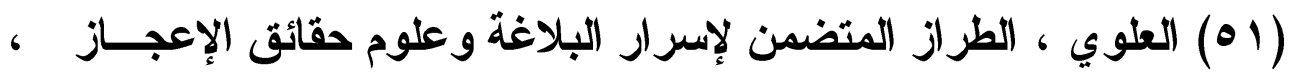

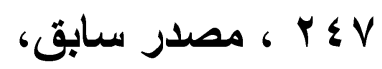

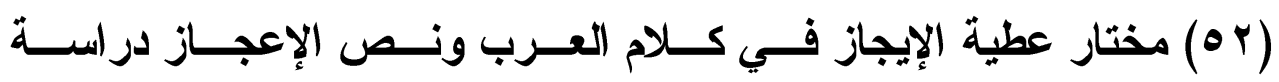

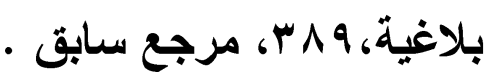

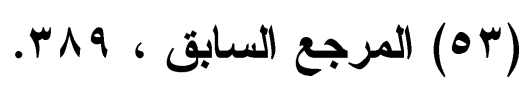

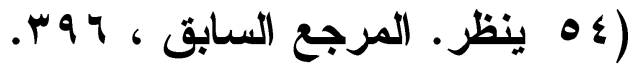

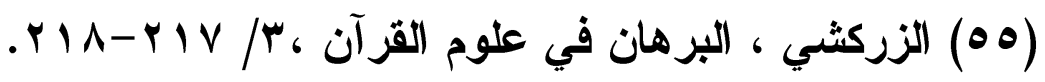

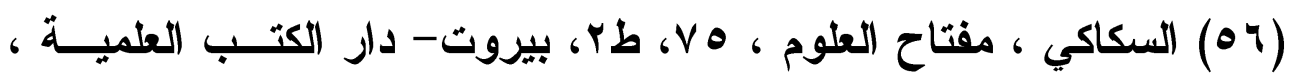
pl91V

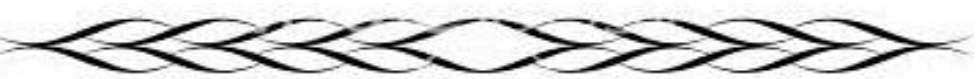




\section{الترقيم الدولم \\ ISSN 2356-9050}

( ع (القاهر الجرجاني ، دلائل الإعجاز ، تحقيق عبد الحميا هنداوي ،

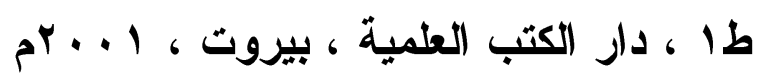

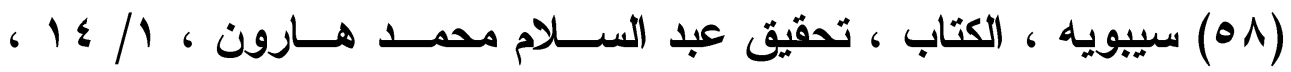

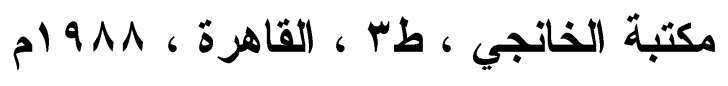

(ه) رجاء عيد ، لغة الشعر ، AV ، القاهرة ، منشأة المعارف ، ه19 ام

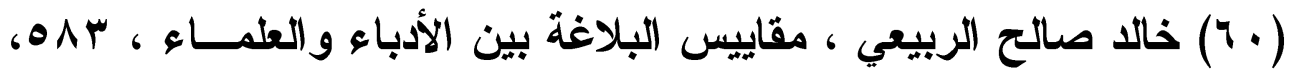

$$
\text { جامعة أم القرى ، } 999 \text { أن } 99
$$

(1 الا) حسن طبل ، علم المعاني في الموروث البلاغــي تأصــيل وتقيــيم ،

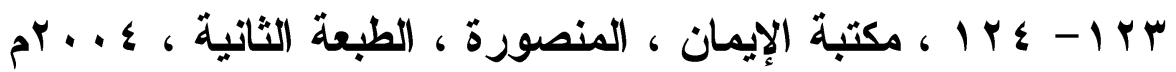

(r ج) فاضل صالح السامرائي ، التعبير القرآني، به، دار عمان ، الأردن ،

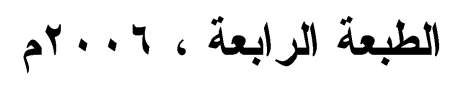

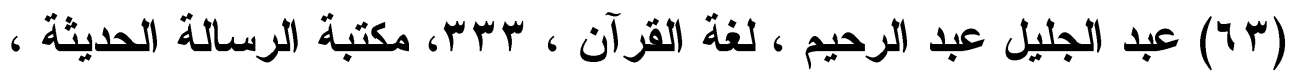

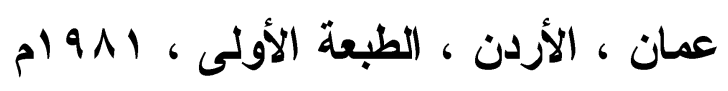

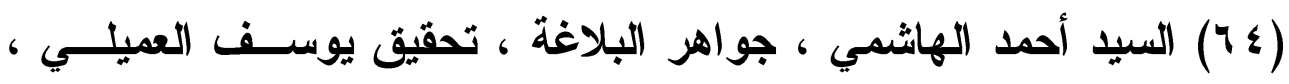

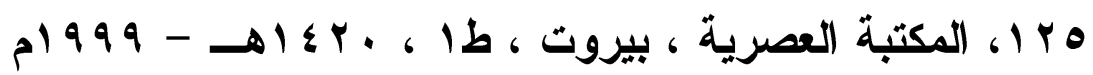

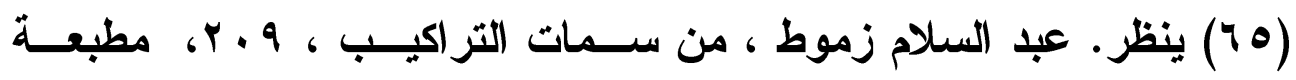

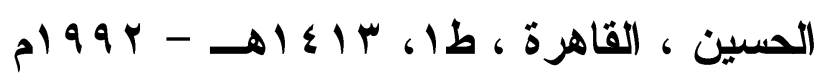

( ד 7) ينظر •برهان الدين البقاعي ، نظم الدرر في تناسب الآيات والسور ،

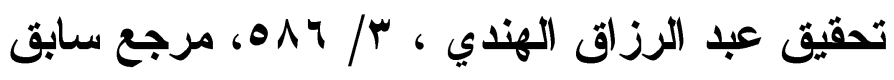

\section{0}


العدول في سورة هود

دراسة أسلوبية

(TV ) (اينظر. الزمخشري ، الكثاف عن حقائف التنزيـلـل ، تحقيـق محمـــ

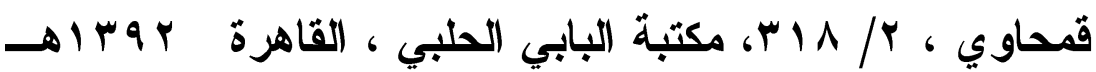

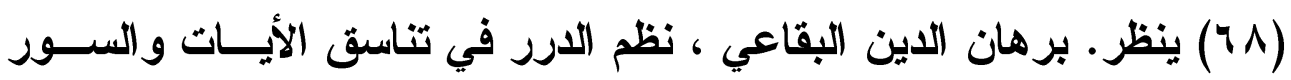

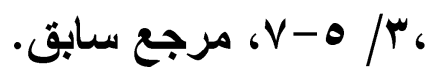

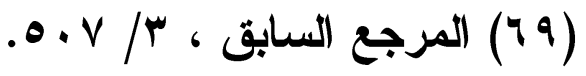

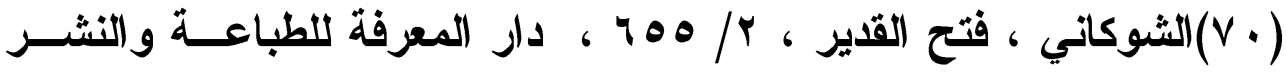

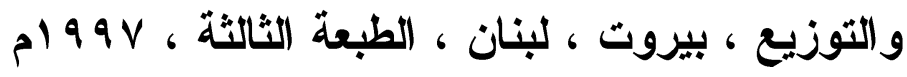

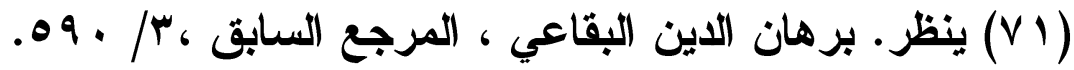

ضياء الدين بن الأثير ، المثل السائر في أدب الكاتب و الثناعر تحقيق د ـ (VY)

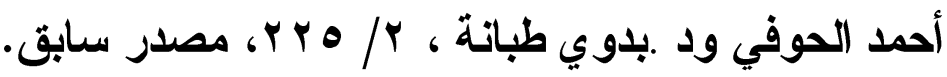

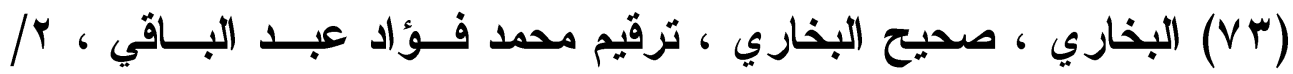

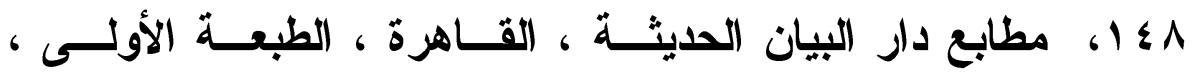

$$
\text { مr..r - }-1 \leqslant r r
$$

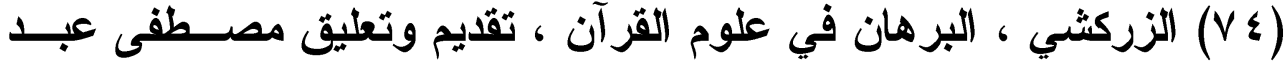

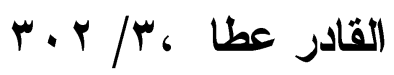

، العلوي ، الطراز المتضمن لإسرار البلاغة وعلوم حقائق الإعجاز ) (V0)

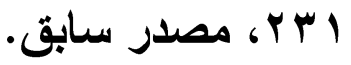

(VT)

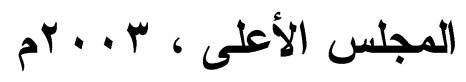




\section{الترقيم الدولم \\ ISSN 2356-9050}

(VV)

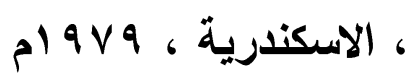

جابر عصفور ، الصورة القنية في التراث النقدي والبلاغي عند العرب (V^)

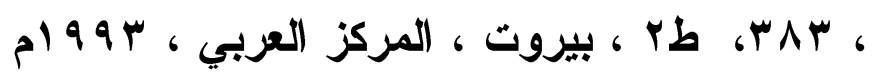

(V9) رجاء عيل ، فلسفة البلاغة بين التغير والتطور ،9 109، مرجع سابق. ( • ( ) ينظر. صلاح الاين عبد التواب ، الصورة الأدبية في القرآن الكريم ، هـ، الثركة المصرية العالمية للنشر - لونجمان - القاهرة ، الطبعة

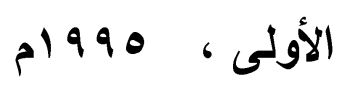

(1) الخطيب القزويني ، الإيضاح في علوم البلاغة ،9 ؛ ؟، مصدر سابق. ( ابن نافيا البغدادي ، الجمان في تشبيهات القرآن ، تحقيق محمد حسن أبي ناجي ، 7 1، طا، مركز الصف الإكتروني ( براج وخطيـب ) ،

$$
\text { p) }
$$

r r ، السيد أحمد الهاشمي ، جواهر البلاغة ، تحقيق يوسف العميلي (NT)

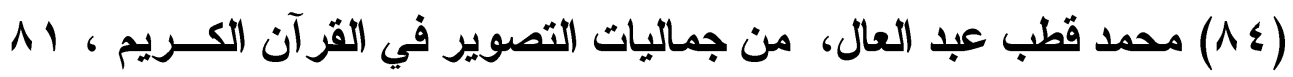
، سلسلة كتاب دعوة للحق العدد V \& 1 ، قطاع الإعلام و الثثافة برابطة

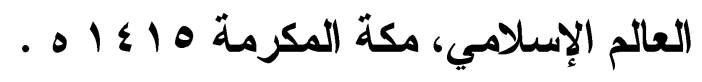

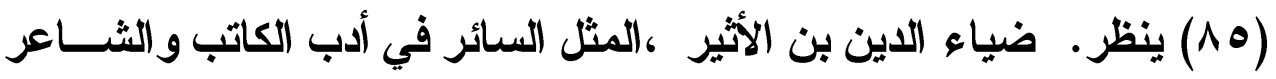

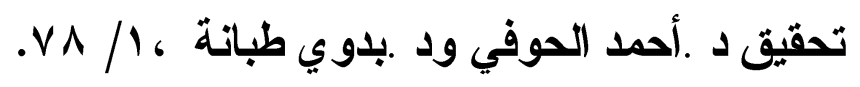

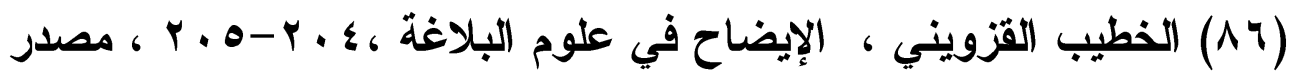




\section{العدول في سورة هود} دراسة أسلوبية

(Av) مجدي وهبة وكامل المهندس ، معجم المصطلحات العربية في اللغــة

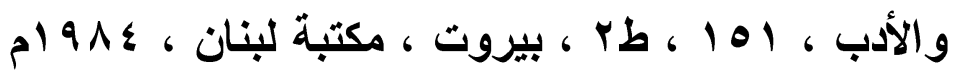

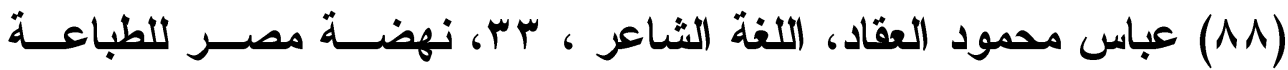

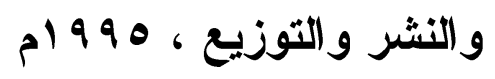

(^9) عبد القاهر الجرجاني ، أسرار البلاغة ،تحقيق · عبد الحميا هنداوي

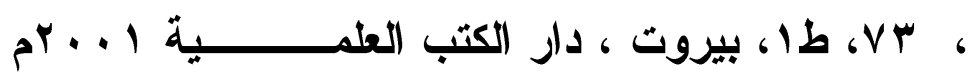

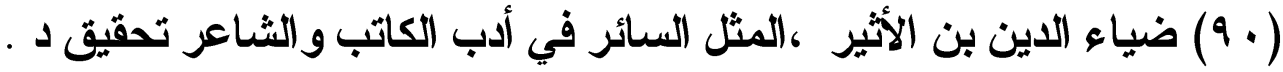

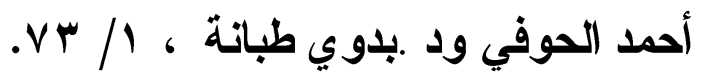

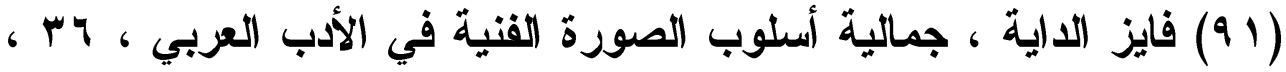

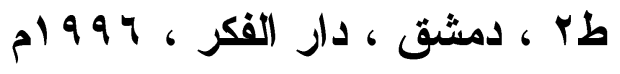

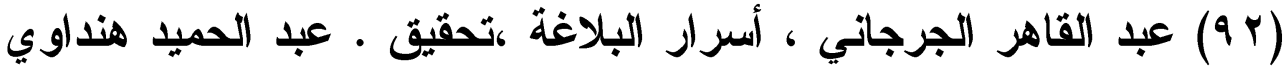
.499 .

(r) ينظر • حسني يوسف عبد الجليل ، التصوير البيـاني بـين القـــماء

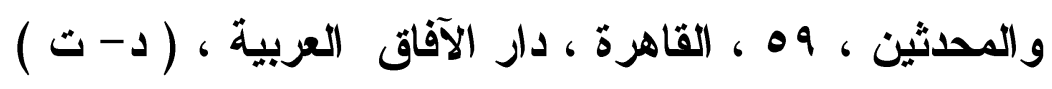

(9 9) محمد رمضان الجربي ، البلاغة التطبيقية - دراســة تحليليــة لعـــم

البيان ، V. V. V، منشورات جامعة ناصر الخمس الجماهيرية العظمسى،

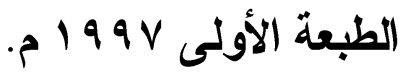

(90) الزركثي ، البرهان في علوم القرآن ، تقديم وتعليق مصــفى عبـــ

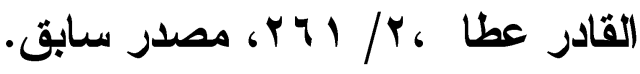




\section{الترقير الدولخ \\ ISSN 2356-9050}

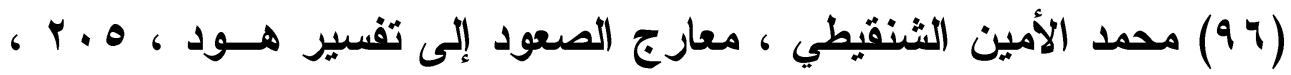

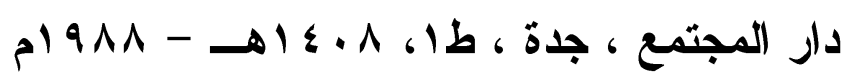

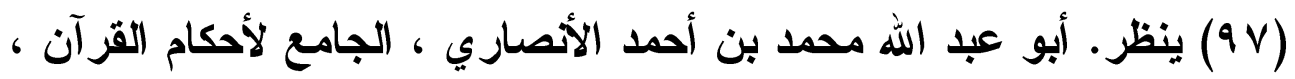
مراجعة وضبط وتعليق محمد إبراهيم الحفناوي 9 / ^ ب، دار الحــديث

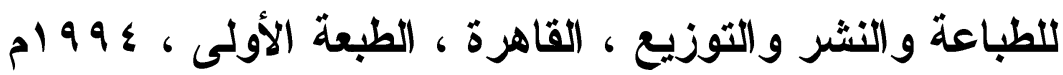

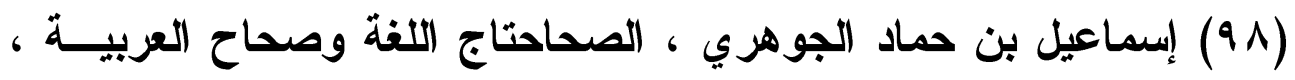

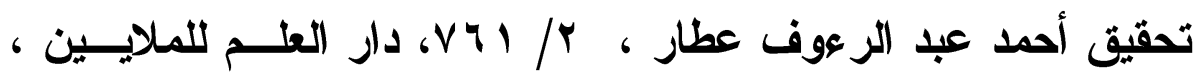

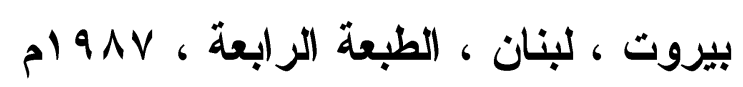

(9 9) ابن رشيق ، العمدة ، تحقيق محمد محي الدين عبـــ الحميـــ ، /

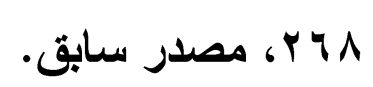

( · ( أبو هلا العسكري ، في الصناعتين ، تحقيق علي محمد البجـاوي

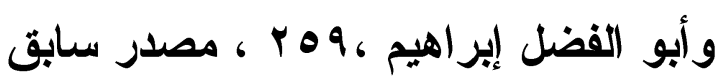

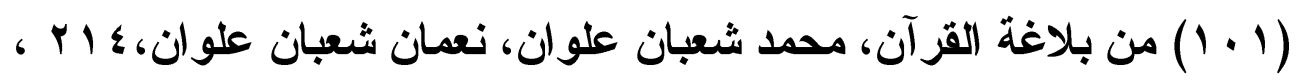

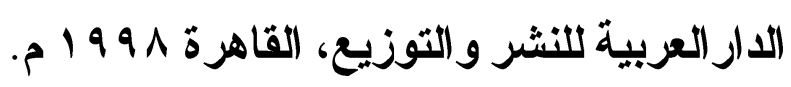

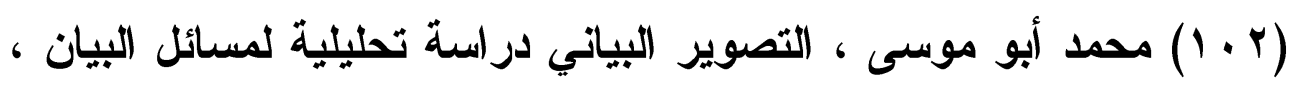

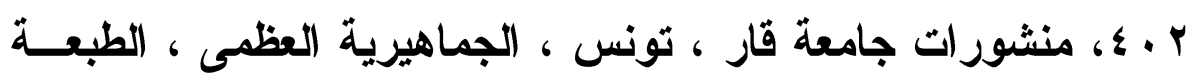

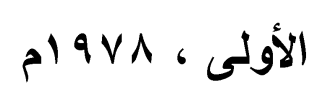

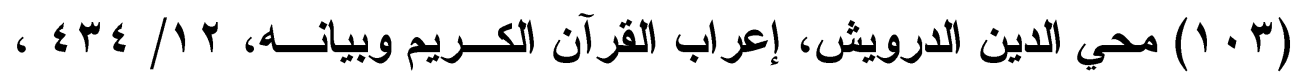
مرجع سابق. 


\section{العدول في سورة هود} دراسة أسلوبية

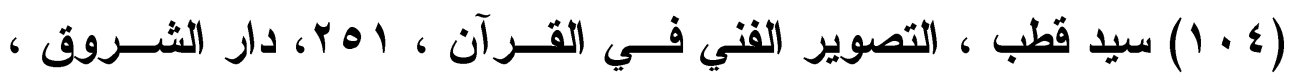

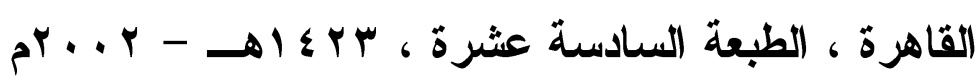

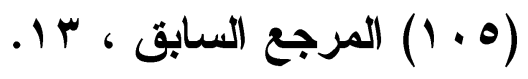

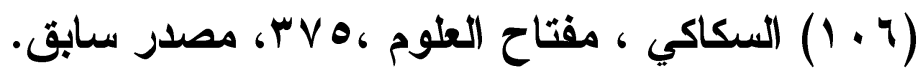

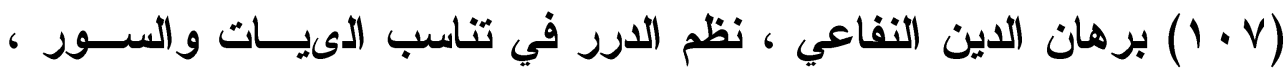

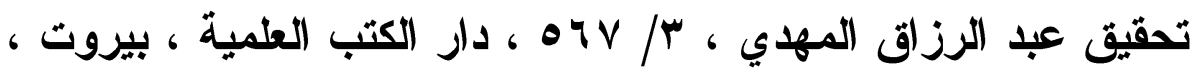

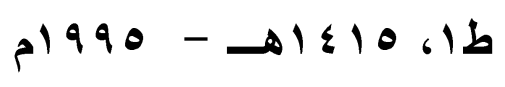

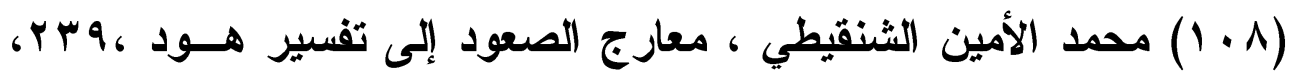
مرجع سابق.

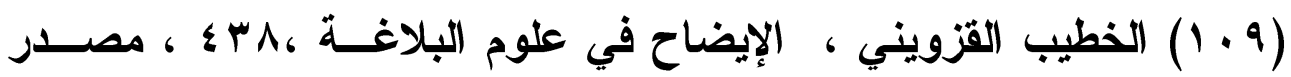
سابق.

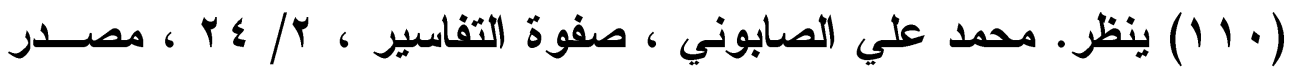
سابق.

(111) (السكاكي ، مفتاح العلوم ، ، 11 ، مصدر سابق.

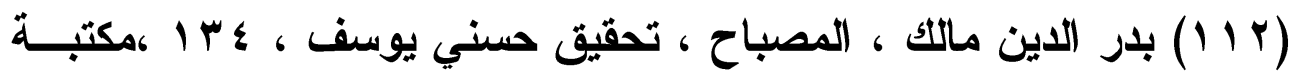

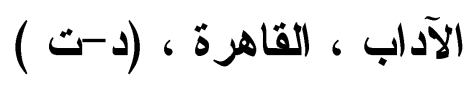

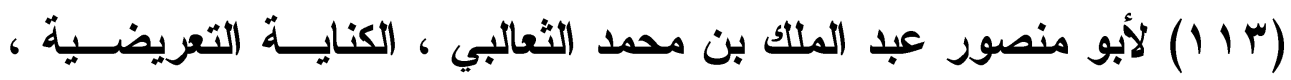

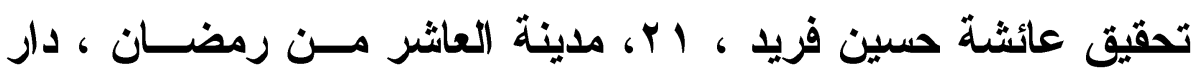

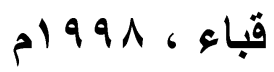




\section{الترقيم الدوله \\ ISSN 2356-9050}

( ع 1 1) محمد جابر فياض ، الكنايسة ، 9 9، طا، جـده ، الســودية ، دار

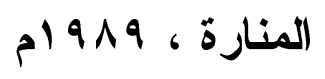

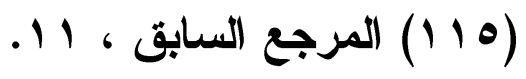

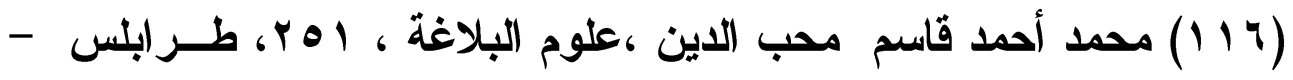

$$
\text { لبنان ، المؤسسة الحديثة للكتاب ، ب . . Y م }
$$

(I IV)

$$
\text { p) } 919-\infty 1 \varepsilon .9
$$

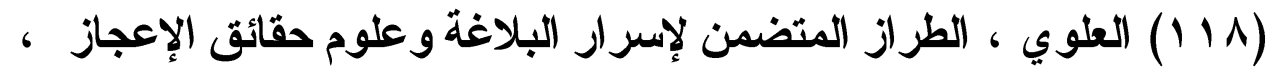
.

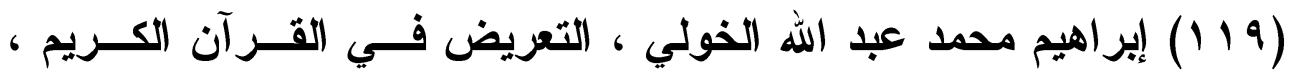

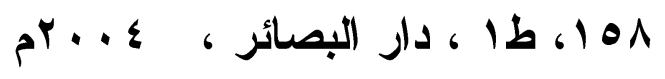

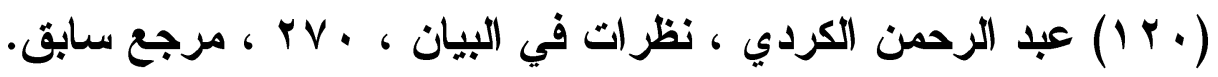

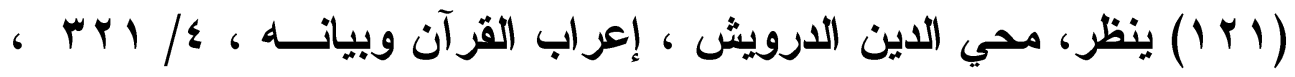
• مرجع سابق

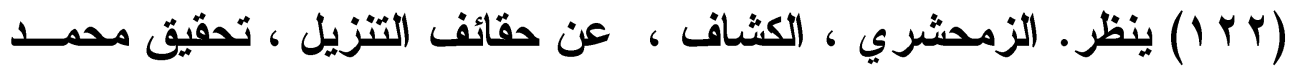
قمحاوي ، Y / • 9 (،مصدر سابق.

\section{0}




\section{العدول في سورة هود دراسة أسلوبية لمورة}

\section{المسادر والمراجع}

(1) إبراهيم محمد عبد الله الخولي ، التعريض في القرآن الكريم ، طا ،

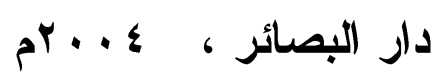

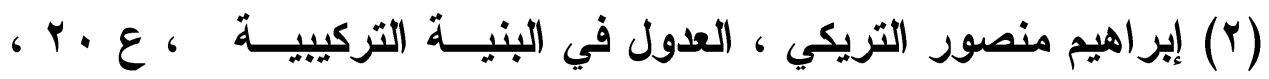

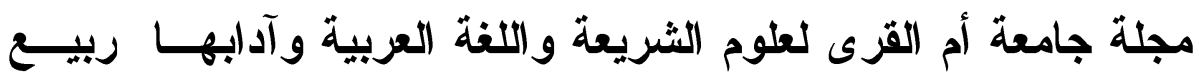

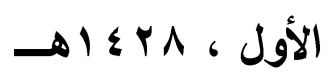

(r) الأزهري ، تهذيب اللغة ، تحقيق محمد عوض مر عب ، مادة عدل ،

$$
\text { بيزوت ، دار إحياء التراث العربي ، } 1 \text {. . rم }
$$

(ع ) أسامة البحيري ، تحولات البنية في البلاغة العربيةة ، دار الحضــارة

$$
\text { للطبع والنشر والتوزيع ، القاهرة ، . . . . م. م. }
$$

(0) إسماعيل بن حماد الجوهري ، الصحاح تاج اللغة وصحاح العربيــة ،

تحقيق أحمد عبد الرعوف عطار ، دار العلم للملايـين ، بيــروت ،

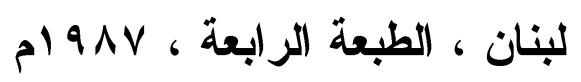

(7) البخاري ، صحيح البخاري ، ترقيم محمد فؤاد عبد الباقي ، مطابع دار البيان الحديثة ، القاهرة ، الطبعة الأولى ، بr ع اهـ - r . . rم

، بلدر الدين مالك ، المصباح ، تحقيق حسني يوسف ، مكتبــة الآداب (V)

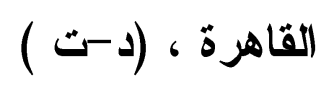

(^) برهان الاين البقاعي ، نظم الارر في تناسث الأيات والســور ، دار

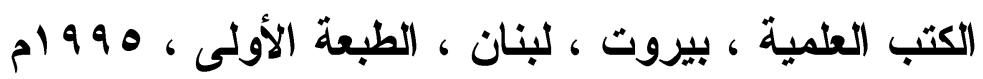




\section{الترقير الدولخ}

ISSN 2356-9050 क. $11 \wedge r$
حولية كلية اللفة العربية بجرجا مجلة علمية محكمة

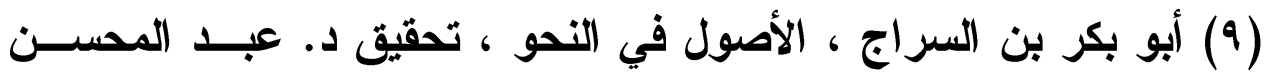

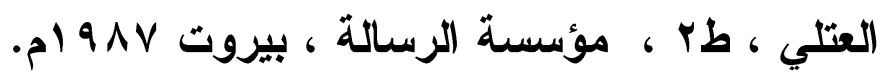

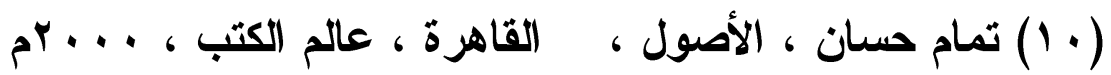

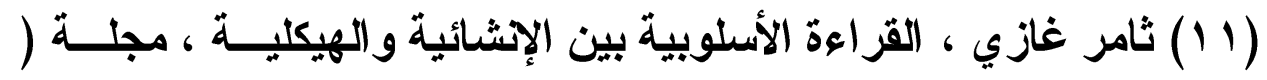

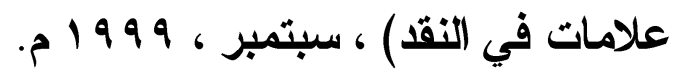

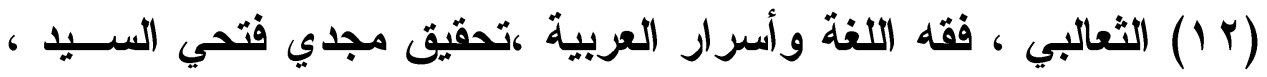

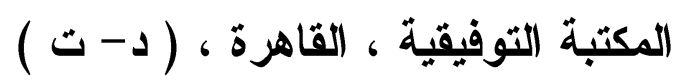

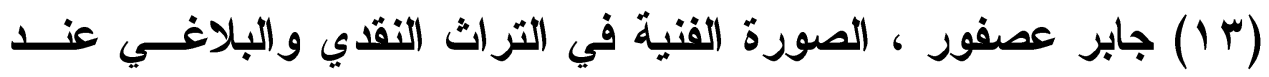

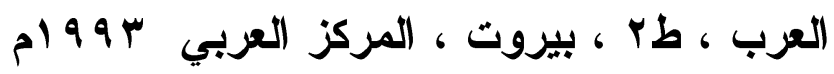

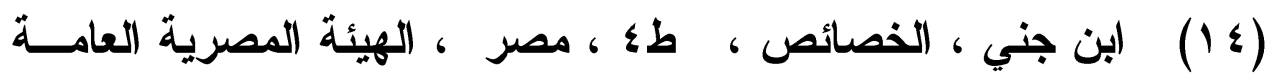

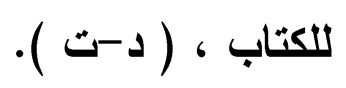

(0 1 ) حسن طبل ، أسلوب الالتفات في البلاغــة القر آنيــة ، دار الفكــر

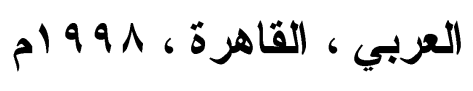

(7 (1) حسن طبل ، علم المعاني في الموروث البلاغي تأصـيل وتقيـيم ،

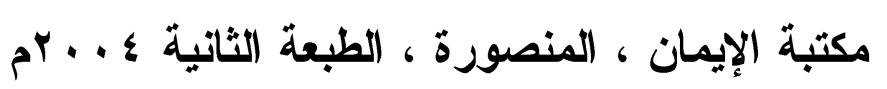

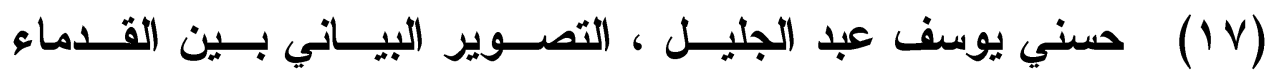

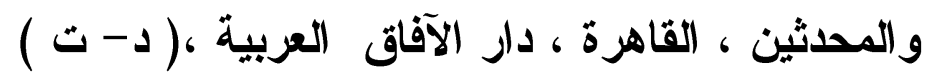

(111) خالد صالح الربيعي ، مقاييس البلاغــة بـين الأدبــاء و العلمــاء ،

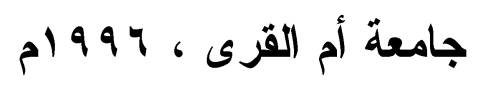


العدول في سورة هود

(9 1) الخطيب القزويني ، الإيضاح في علوم البلاغــة ، دار الكتــاب

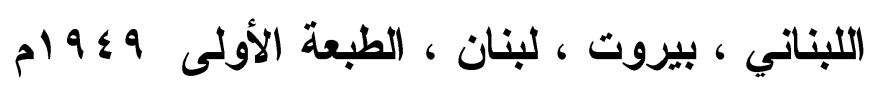

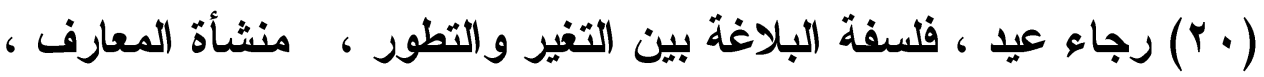

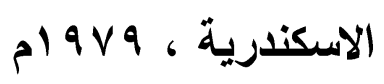

(Y (Y) رجاء عيد ، لغة الثعر ، القاهرة ، منشأة المعارف ، ه191 ام

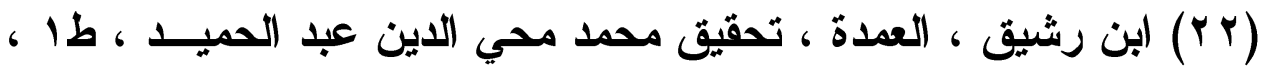

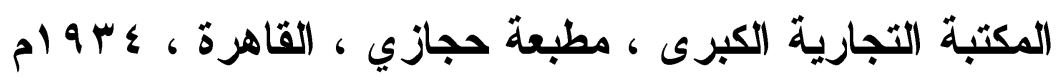
^ §) الزجاج ، إعراب القرآن المنسوب إلى الزجاج، تحقيق ودراسة إبر اهيم

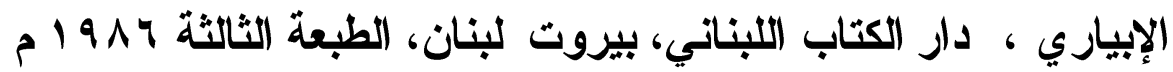

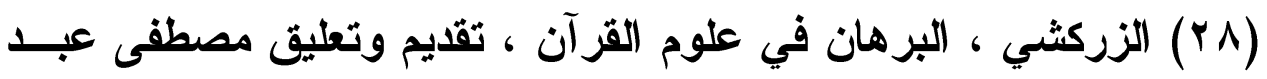
القادر عطا ،دار الفكر للطباعة والنشر والتوزيع ، بيروت - لبنان

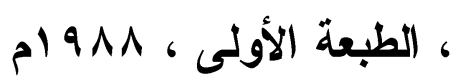

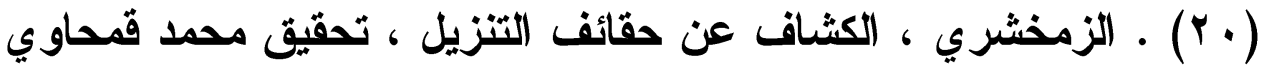

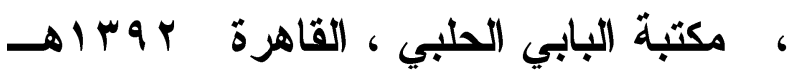

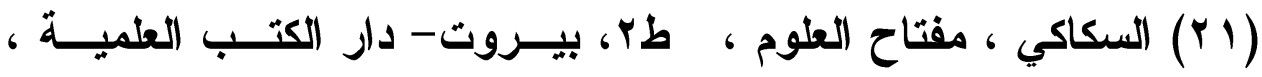

$$
\text { م) 9Av }
$$

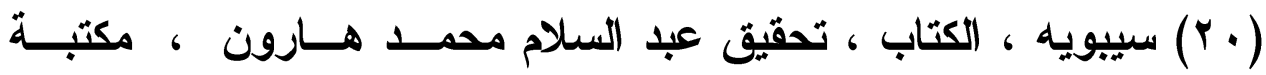

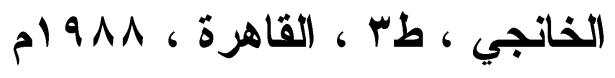

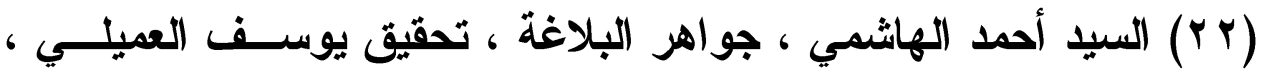

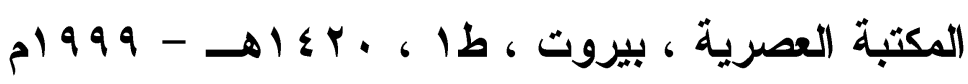




\section{الترقيم الدوله \\ ISSN 2356-9050}

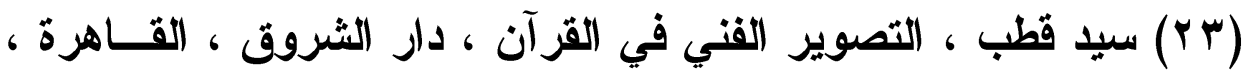

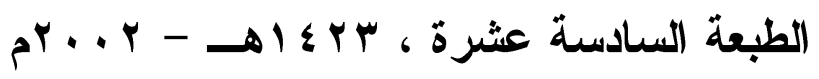

( ع r) الثوكاني ، فتح القدير ،دار المعرفة للطباعة والنشــر والتوزيــع ،

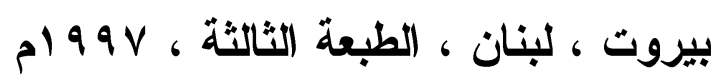

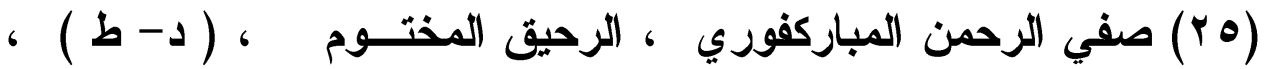

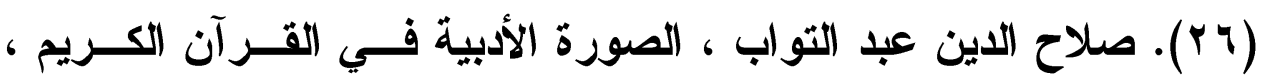
الشركة المصرية العالمية للنشر - لونجمــان - القــاهرة ، الطبعـة

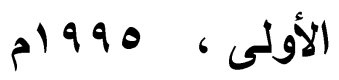

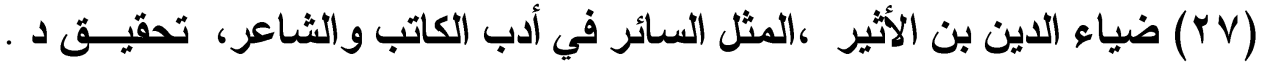
أحمد الحوفي ود .بدوي طبانة ـ مكتبة النهضة المصرية ،القاهرة 909 ام

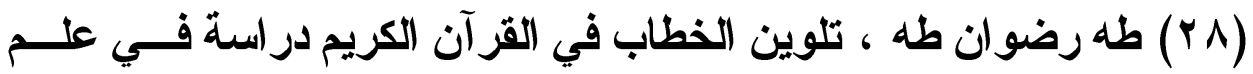
الأسلوب وتحليل النص، دار الصــحابة للتــر اث والطباعـة و النشــر

$$
\text { والتوزيع، طنطا، الطبعة الأولى V . . r م. }
$$

(Yq) عباس فضل حسن ، البلاغة فنونها وأفنانهـــا ، ط؛ ، إربـــ ، دار

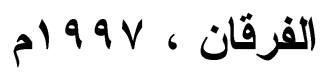

( • ب) عباس محمود العقاد، اللغة الشاعرة ، نهضــة مصـر للطباعـة

$$
\text { والنشر والتوزيع ، } 990 \text { أبمس }
$$

(1) عبد الجليل عبد الرحيم ، لغة القرآن ، مكتبة الرسالة الحديثـة ،

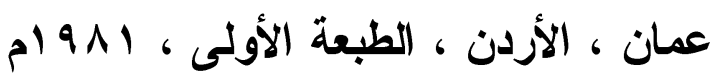




\section{العدول في سورة هود} دراسة أسلوبية لمورة 1 1110
العدد الثالث والعشروز للعام 19 العزئ الجزء الثاني

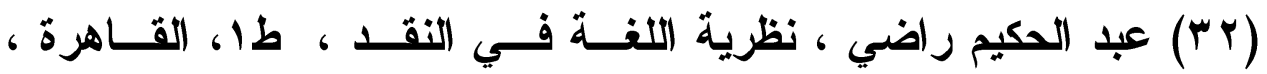

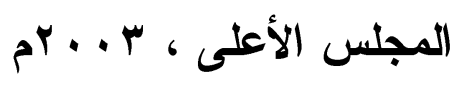

(Tr) عبد الحميد أحمد يوسف هنداوي .الإعجاز الصرفي في القرآن الكريم :

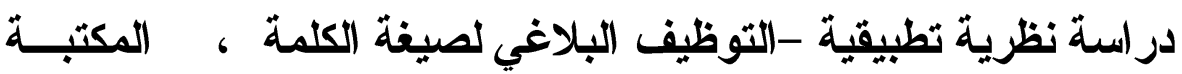

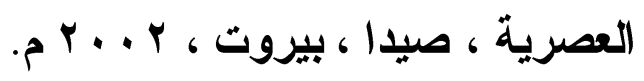

( ع آ) عبد الرحمن حسن حبنكة الميداني ، البلاغة العربية أسسها وعلومها

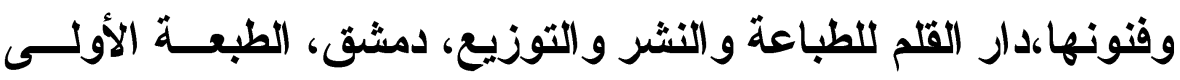

$$
\text { م) } 999
$$

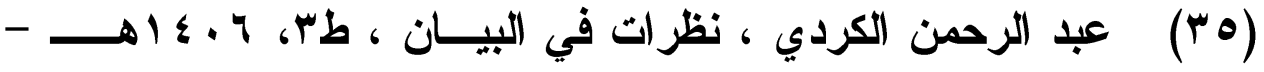

$$
\text { م) } 914
$$

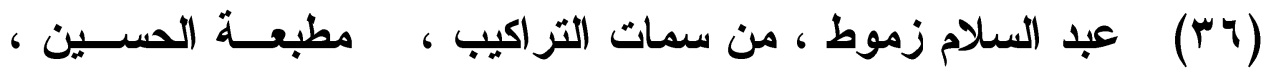

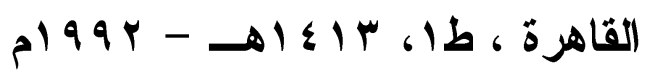

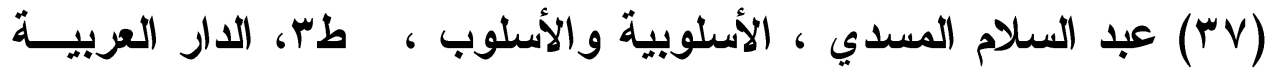

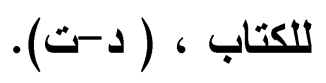

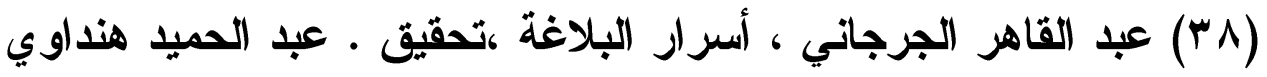

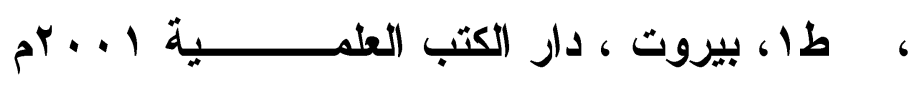

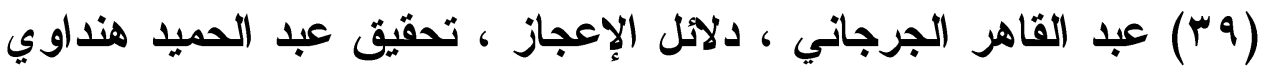

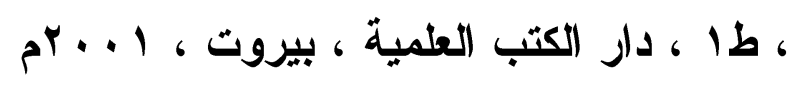

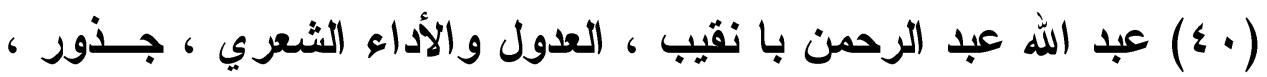

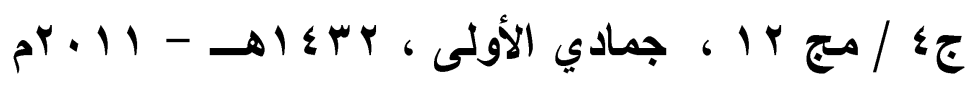




\section{الترقير الدولخ}

ISSN 2356-9050
Q 1114

حولية كلية اللفة العربية بجرجا مجلة علمية محكمة

(1) أبو عبد الله محمد بن أحمد الأصصاري ، الجامع لأحكام القــرآن ، مراجعة وضبط وتعليق محمد إبر اهيم الحفناوي د دار الحديث للطباعــة و النشر والتوزيع ، القاهرة ، الطبعة الأولى ، ؛ 99 ام ( ) عبد الموجود متولي بهنسي ، روئية العدول عن النمطية في التعبيز الأدبي ، الرياض ، مكتبة الرشد للتشر والتوزيع ، ب9 9 ام

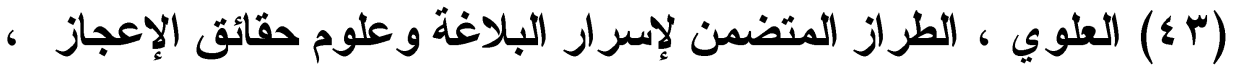
مراجعة وضبط وتدقيق محمد عبد السلام شاهين دار الكتب العلمية، بيروت لبنان، الطبعة الأولى ه99 99 م.

(ع \&) فاضل صالح السامرائي ، التعبيز القرآني، دار عمـــان ، الأردن ،

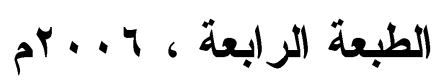

(0) فايز الاية ، جمالية أسلوب الصورة القنية في الأدب العربي ، طץ ،

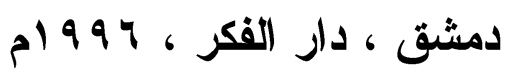

(7 ) الفيروز أبادي ، القاموس المحيط ، تحقيق. أنس محمـــ الثــامي وزكريا جابر أحمد ، مادة عدل ، القاهرة ، دار الحديث، 1 ، . بم

(\&V) القاضي أبو محمد الألدلسي ، المحرر الوجيز ، تحقيق عبد السلام عبد الشافي محمد ، دار الكتب العلمية ، بيزوت - لبنــان ، الطبعـة

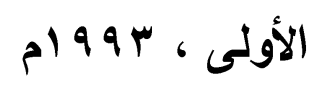

(^) ـ مجدي وهبة وكامل المهندس ، معجم المصطلحاث العربية في اللغة

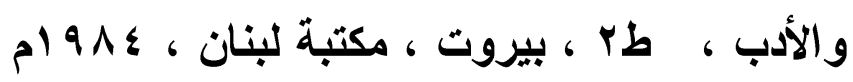




\section{العلدول في سورة هود دراسة أنسلوبية}

(9 §) محمد أحمد قاسم محب الدين ،علوم البلاغة ، طر ابلس - لبنان ،

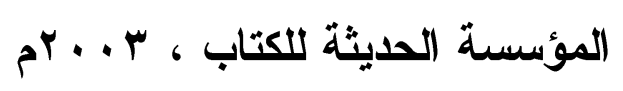

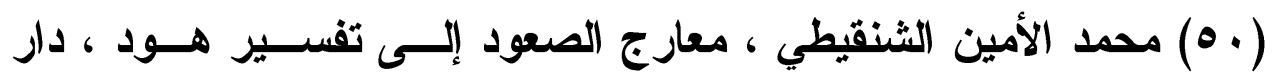

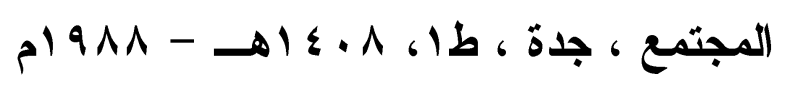

(10) محمد جابر فياض ، الكناية ، طا، جله ، السعودية ، دار المنارة ،

$$
\text { م) } 919
$$

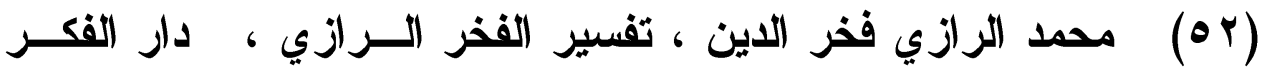

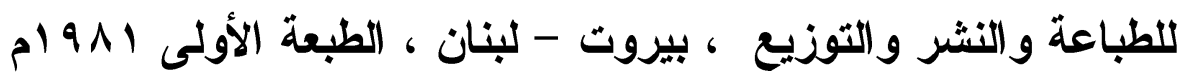

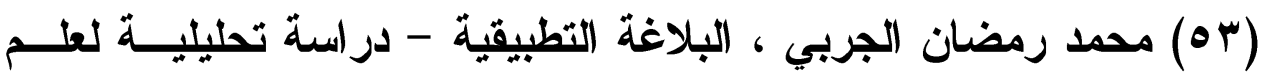

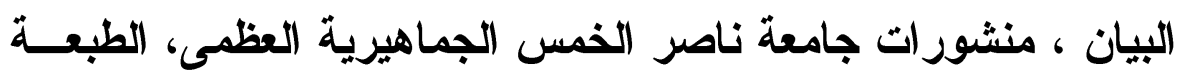

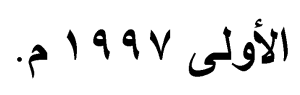

( ـ ه) محمد شعبان علوان،من بلاغة القرآن، الدار العربية للنشر والتوزيع،

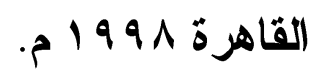

(7) محمد صلاح زكي أبو حميد ، الخطــاب الثــعري عنـــ محمــود

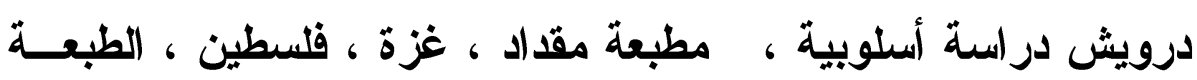

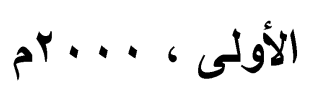

(OV) محمد علي الصابوني ، صفوة التفاسـير ، دار إحيـاء التــراث

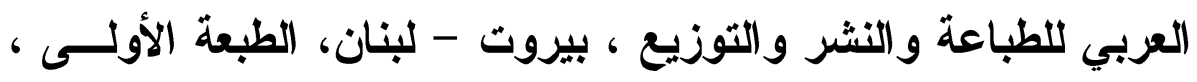

$$
\text { مr... }
$$




\section{الترقير الدولخ}

ISSN 2356-9050
Q 1111
حولية كلية اللفة العربية بجرجا مجية مجية مجلة علمية محكمة

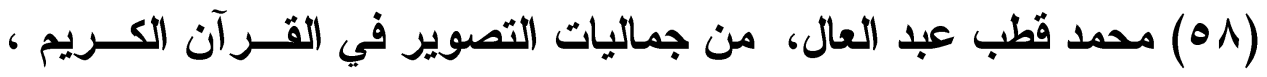
سلسلة كتاب دعوة للحق العدد قطاع الإعلام والثقافة بر ابطة العـالم

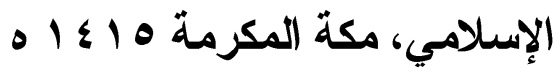

(9 ه) محمد أبو موسى ، التصوير البياني دراسة تحليلية لمسائل البيان ، منشورات جامعة قار ، تونس ، الجماهيرية العظمى ، الطبعة الأولى ، ค) $9 \vee \wedge$

( · ( )محي الدين الارويش ، إعراب القزآن وبيانه ، دار اليمامة للطباعة

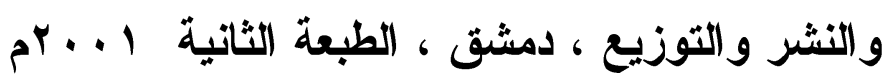

(1 (1) مختار عطية، الإيجاز في كلام العرب ونص الإعجاز دراسة بلاغية، دار المعرفة الجامعية الإسكندرية 99 V 19 م.

(Y T) أبو منصور عبد الملك بن محمد الثعالبي ، الكنايــة التعريضــية ، تحقيق عائشة حسين فريد ، مدينة العاشر من رمضان ، دار قبــاء ،

$$
\text { ค) } 991
$$

(T 7) ابن منظور ، لسان العرب ، مادة عدل ، طף، بيروت ، دار صادر ،

$$
\hat{r}^{r} \cdot \Lambda
$$

(ع ا) ابن ناقيا البغدادي ، الجمان في تشبيهات القرآن ، تحقيـق محمــ حسن أبي ناجي ، طا، مركز الصف الإكتروني ( براج وخطيب ) ،

$$
\text { p) } 9 \wedge V 61 b
$$

(0) أبو هلال العسكري ، في الصناعتين ، تحقيق علي محمد البجـاوي

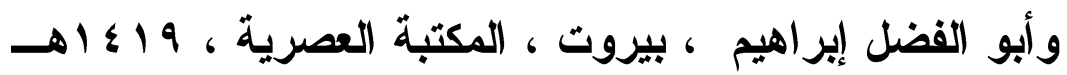




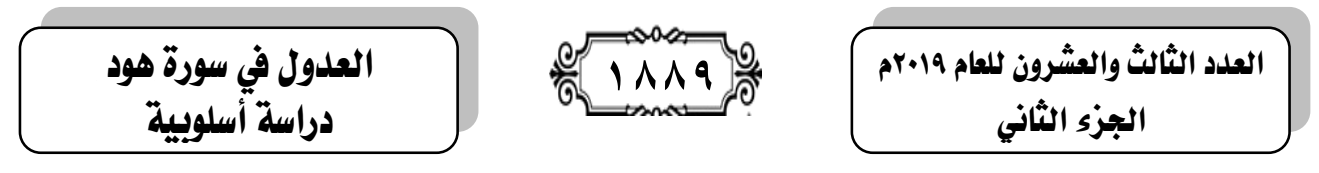 \\ فهرس الإوضووهات}

\begin{tabular}{|c|c|c|}
\hline صنصi & & $\theta$ \\
\hline 1111 & & 1 \\
\hline $1 \wedge 1 \mathrm{r}$ & Abstract & $r$ \\
\hline $1 \wedge 1 r$ & & $r$ \\
\hline $1 \wedge 1 r$ & لغنة: & $\varepsilon$ \\
\hline $1 \wedge \mid \varepsilon$ & Lالام & $\bullet$ \\
\hline$|\wedge r|$ & الهدول في التزكيسب & 7 \\
\hline INTr & ت ت ت ت ت & v \\
\hline IArV & & $\Lambda$ \\
\hline INHo & والتأخيز & 9 \\
\hline $1 \wedge \varepsilon r$ & يى: العهدول في الصور البلاغية & $1 \cdot$ \\
\hline $1 \wedge \varepsilon r$ & ثنبـيـه & 11 \\
\hline $1 \wedge \leqslant V$ & ا : المجاز & Ir \\
\hline 1109 & |لكنابة & ir \\
\hline $1 \wedge 70$ & الخاتمهة & $1 \varepsilon$ \\
\hline \^५^ & ل & 10 \\
\hline$|\wedge \wedge|$ & الهادر والدراجع & 17 \\
\hline $1 \wedge \wedge 9$ & معات & iv \\
\hline
\end{tabular}

